INTER NATIONAL MONETARY FUND
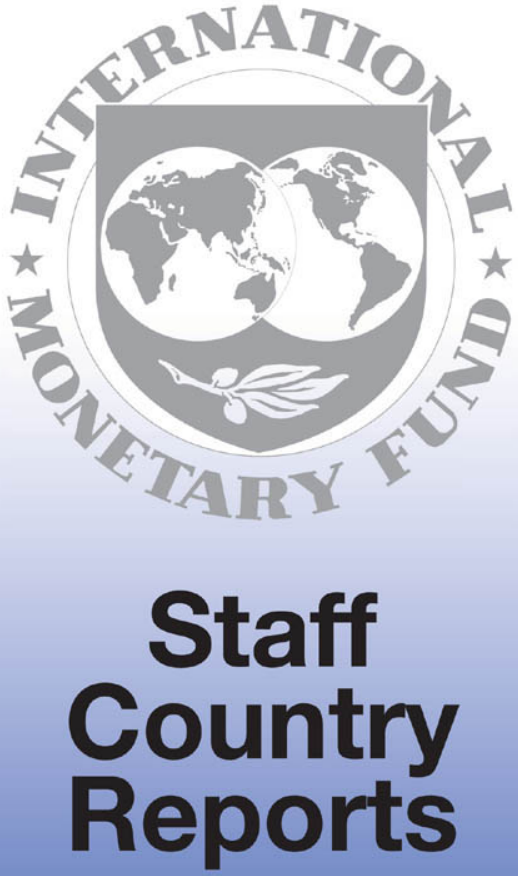


\section{Madagascar: Selected Issues and Statistical Appendix}

This Selected lssues paper and Statistical Appendix for Madagascar was prepared by a staff tcam of the International Monetary Fund as background documentation for the periodic consultation with the member country. It is based on the information available at the time it was completed on December 6, 2002. The views expressed in this document are those of the staff team and do not necessarily reficet the views of the government of Madagascar or the Exccutive Board of the IMF.

The policy of publication of staff reports and other documents by the IMF allows for the deletion of market-scnsilive information.

To assist the IMF in evaluating the publication policy, reader comments are invited and may be sent by e-mail to Publicationpolicy@imf.org.

Copies of this report are available to the public from International Monetary Fund - Publication Services 700 19th Street, N.W. • Washington, D.C. 20431 Telephone: (202) 6237430 - Telefax: (202) 6237201

E-mail: publications@imf.org • Internet: http://www.imf.org

Price: $\$ 15.00$ a copy

\section{International Monetary Fund Washington, D.C.}


INTERNATIONAL MONETARY FUND

MADAGASCAR

Selected Issues and Statistical Appendix

Prepared by a staff team consisting of $F$. Sacerdoti (head),

J. Cady, C. Sancak, B. Ould-Abdallah (all AFR), and R. Luzio (PDR)

Approved by the African Department

December 6,2002

Contents

Page

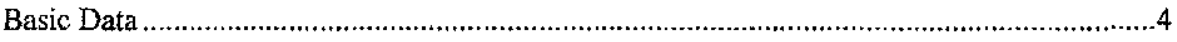

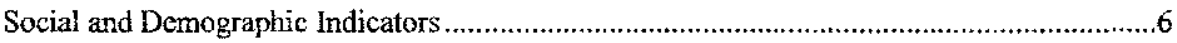

I. Recent Economic Developments and Policies ...............................................................

A. Real Sector ...................................................................................................

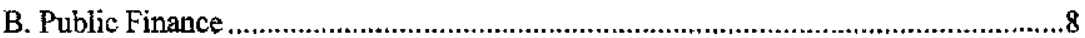

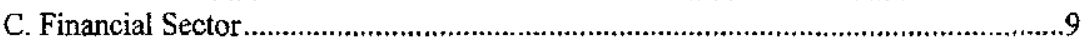

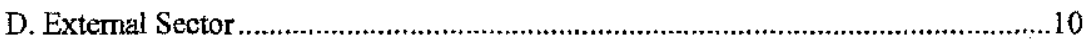

E. Structural Reforms...................................................................................12

II. Economic and Social Impact of the Political Crisis........................................................13

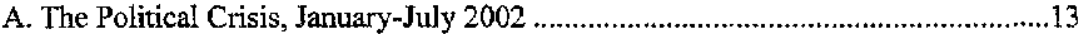

B. Economic Impact of the Political Crisis.........................................................15

C. Social Impact of the Political Crisis ..................................................................17

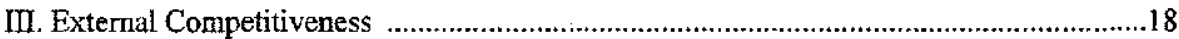

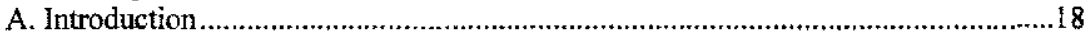

B. Equilibrium Real Exchange Rate Assessment ..................................................19

C. Relative Labor Cost Analysis.........................................................................19

D. Constant Market Share Analysis.......................................................................20

E. Conclusions ....................................................................................................22

Boxes

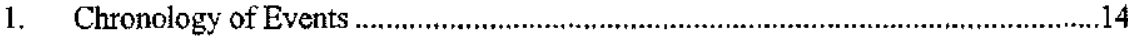

2. Economic Impact of the Political Crisis ..................................................................15 
Figures

1. Selected Economic and Financial Indicators, 1997-2001 ................................23

2. Real Sector Developments, 1997-2001 ....................................................24

3. Fiscal Sector Developments, 1997-2001 .................................................25

4. Money, Consumer Prices, and Treasury Bill Yields, 1997-2001 .....................26

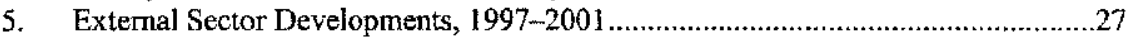

6. Real and Nominal Exchange Rates, January, 1990-August 2002 .....................28

7. Foreign Direct Investment, 1970-2000 ......................................................29

8. Madagascar and Selected Comparator Countries:

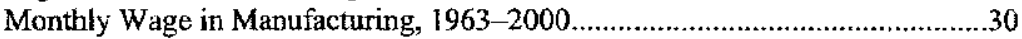

9. Constant-Market-Share Export Growth Decomposition, 1992-2001 .................31

\section{Appendices}

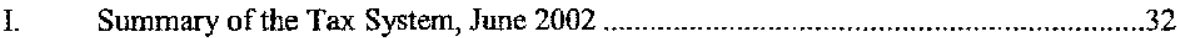

II. Statistical Appendix Tables:

1. Growth and Structure of GDP, 1997-2001 ...............................................45

2. Gross Domestic Product at Constant 1984 Prices, 1997-2001...................46

3. Supply and Use of Resources at Current Prices, 1997-2001....................47

4. Production of Rice and Other Food Crops, 1997-2001 ........................48

5. $\quad$ Rice Production, Imports, and Availability, 1981-2001 .........................49

6. Retail Prices of Ordinary Rice, 1997-2001 .............................................50

7. Production of Major Cash Crops, 1997-2001 ........................................51

8 . Indicative Minimum Producer Prices for Major Crops, 1997-2001 .............52

9. Index of Industrial Production, Excluding the EPZ, 1997-2001 .................53

10. Industrial Production, 1997-2001 .................................................54

11. Economic Activities of Manufacturing Enterprises

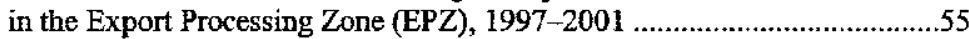

12. Number of Enterprises with Operating Permits

Under the Export Processing Zone Regime, 1997-2001 ..........................56

13. Production and Export of Major Minerals, 1997-2001 .............................57

14. Tourism Indicators, 1997-2001 ............................................................58

15. Production and Consumption of Electricity, 1997-2001 ..........................59

16. Prices of Petroleum Products, 1997-2001 …..............................................60

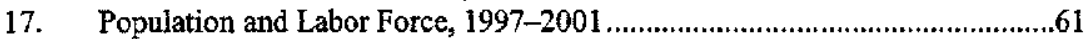

18. Distribution of Population and Civil Servants, 1997-2001 .......................62

19. Minimum and Maximum Monthly Wages, 1994-2001 ..............................63

20. Consumer Price Index by Product, 1997-2000 ...................................64

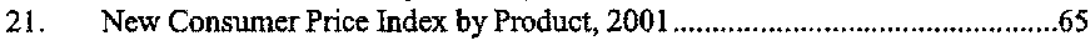

22. Central Government Financial Operations, 1997-2001 .............................66

23. Central Government Fiscal Indicators, 1997-2001 ............................67

24. Budgetary Revenue, 1997-2000 .....................................................68

25. Current Budgetary Expenditure, 1997 -2001 .....................................69

26. Central Government Capital Expenditure, $1997-2001 \ldots \ldots \ldots \ldots \ldots \ldots \ldots \ldots \ldots \ldots \ldots \ldots .70$ 
27. Central Government Personnel Expenditure and Number of Civil Seryants, 1997-2001 ...................................................71

28. Structure and Adjustment of Public Sector Salaries, 1997-2002 ................72

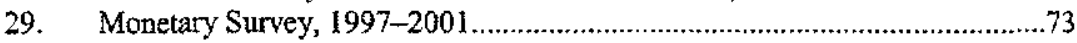

30. Summary Accounts of the Central Bank, 1997-2001 _...............................74

31. Summary Accounts of Commercial Banks, 1997-2001 …............................75

32. Foreign Reserve Assets and Liabilities of the Central Bank, 1997-2001 .......76

33. Structure of Market Interest Rates, 1997-2002 _.......................................77

34. Structure of Commercial Bank Interest Rates, 1997-2001 …........................78

35. Issues and Outstandings of Treasury Bills, 1997-2001,............................79

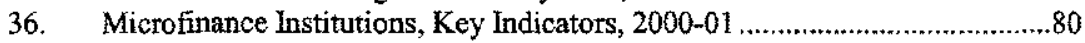

37. Summary Balance of Payments 1997-2001 .............................................81

$38 \quad$ Composition of Exports, f.o.b., 1997-2001 …......................................83

39. Composition of Imports, c.i.f, 1997-2001 …...........................................85

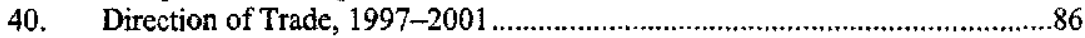

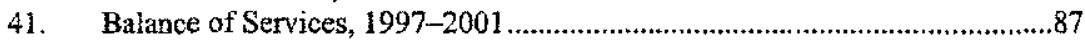

42. Stock of External Debt, 1997-2001 ............................................................88 
Madagascar: Basic Data

Area, population, and GDP per capita

Area: 582,000 square kilometers

ropulation

Total: 16 million (2001)

Gowth rate: 3.1 percent (1999)

GDP per capita (World Bank Atlas method): US\$260 (2001)

$\begin{array}{lllll}1997 & 1998 & 1999 & 2000 & 2001\end{array}$

National acounts

GDP at current prices

GDP ai constant 1984 prices

GDP at market prices

Primary sector (at factor cost)

Secundary sector (at factor cost)

Tertiary sector (at factor cost)

Consumption

Gross domestic investment

Gross dontestic savings

Current account balence

Price movernents

GDP deflator

Consumer price index (traditional basket) ${ }^{2}$

Government finance

Current revenue and grants

Current expenditure

Capital expenditare

Overall balance on a casb basis (deficit -)

Net domestic financing

Of which: dornestic banks (net)

(In billions of Malagasy francs)

$\begin{array}{rrrrr}18,051 & 20,343 & 23,379 & 26,242 & 30,334 \\ 2,046 & 2,126 & 2,225 & 2,331 & 2,471\end{array}$

(Anuual percentage change at 1984 prices)

$3.7 \quad 3.9$

1.92 .1

$4.7 \quad 5.3$

$4.7 \quad 5.1$

\section{7}

3.4

4.8

0.8

5.6

5.5

6.7

6.0

4.0

7.6

(ln percent of GDP)

$\begin{array}{rrrrr}95.3 & 93.0 & 92.8 & 92.3 & 87.7 \\ 12.8 & 14.8 & 14.9 & 15.0 & 15.5 \\ 4.7 & 7.0 & 7.2 & 7.7 & 12.3 \\ -5.5 & .7 .4 & -5.4 & -5.7 & -1.3\end{array}$

(Annual percentage change)

7.3

4.8

$\begin{array}{rr}8.4 & 9.8 \\ 6.4 & 14.4\end{array}$

(In billions of Malagasy francs)

$\begin{array}{rrrrr}2,703.2 & 2,872.6 & 3,509.9 & 4,014.4 & 4,190.6 \\ 1,960.2 & 2,146.1 & 2,175.0 & 2,402.5 & 3,081.7 \\ 1,176.9 & 1,673.1 & 1,615.9 & 1,766.1 & 2,180.9 \\ -573.3 & -1,285.2 & -583.1 & -872.8 & -1,322.0 \\ & & & & \\ -119.0 & 901.5 & 246.4 & 121.9 & 580.9 \\ -146.0 & 741.2 & 167.1 & 3.1 & 468.4\end{array}$

(ln percent of GDP)

Overall deficit, commitment basis, excluding total grants Overall balance on a cash basis, including grants (deficit -)

$-6.3$

$-2.5$

$-3.3$

Money and credit

(In billions of Malagasy franes)

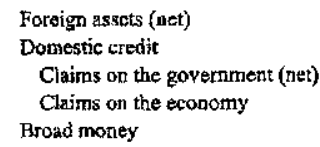

$\begin{array}{rrrrr}1,771.1 & 1,172.0 & 1,711.5 & 2,006.3 & 2,571.1 \\ & & & & \\ 584.3 & 1,325.5 & 1,560.7 & 1,563.3 & 2,047.8 \\ 1,814.1 & 1,828.2 & 1,955.4 & 2,415.0 & 2,778.3 \\ 3,846.2 & 4,169.1 & 4,981.1 & 5,916.8 & 7,357.7\end{array}$




\begin{tabular}{|c|c|c|c|c|c|}
\hline & 1997 & 1998 & 1999 & 2000 & 2001 \\
\hline & \multicolumn{5}{|c|}{ (Annual percent change) } \\
\hline \multicolumn{6}{|l|}{ Domestic credit } \\
\hline Claims on the government (net) & -20.0 & 126.9 & 17.7 & 0.2 & 31.0 \\
\hline Claims on the econony & 13.4 & 0.8 & 7.0 & 23.5 & 15.0 \\
\hline Broad money & 19.8 & 8.4 & 19.5 & 18.8 & 24.4 \\
\hline Balance of payments & \multicolumn{5}{|c|}{ (In millions of SDRs, unless otherwise indicated) } \\
\hline Exports, f.o.b. & 368.5 & 385.0 & 427.1 & 628.5 & 757.9 \\
\hline Imports, fo.b. & -495.6 & -495.5 & -543.0 & -707.1 & -746.3 \\
\hline Trade balance & -127.1 & -110.5 & -115.9 & -78.6 & 11.6 \\
\hline Services (net) & -81.1 & -103.3 & -94.8 & -136.2 & -125.9 \\
\hline Of which: interest payments due & 75.8 & 67.2 & 39.8 & 40.1 & 44.4 \\
\hline Unrequited mansfers (net) & 132.1 & 63.0 & 94.6 & 102.6 & 114.6 \\
\hline Private transfers (net) & 74.3 & 50.4 & 68.8 & 77.1 & 89.7 \\
\hline Public transfers (net) ${ }^{3}$ & 57.8 & 12.6 & 25.8 & 25.5 & 24.9 \\
\hline \multicolumn{6}{|l|}{ Current account balance } \\
\hline In percent of GDP ${ }^{4}$ & -5.5 & -7.4 & -5.4 & -5.6 & -1.3 \\
\hline Capital transfers & 77.6 & 73.5 & 94.2 & 87.0 & 88.6 \\
\hline Of which : drawings & 155.5 & 90.2 & 75.0 & 86.9 & 90.2 \\
\hline amortization & -77.4 & .89 .7 & -77.1 & -78.2 & -68.7 \\
\hline direct investment & 10.0 & 11.9 & 42.7 & 52.9 & 73.1 \\
\hline Overall balance & 19.7 & -126.6 & -9.9 & -82.3 & 21.1 \\
\hline Debt telief and cancellation & 803.0 & 38.0 & 40.8 & 59.6 & 55.8 \\
\hline IMF (net) & 0.7 & -10.3 & 9.7 & 34.8 & 21.4 \\
\hline Arrears (reduction -) & -783.2 & 12.0 & 3.1 & -5.7 & 0.0 \\
\hline Reserves (net) (increase -) & -39.5 & 76.6 & -34.0 & 28.4 & .76 .9 \\
\hline Gross official reserves ${ }^{s}$ & 14.1 & 7.8 & 9.8 & 10.2 & 14.4 \\
\hline Outstanding external debt ${ }^{6}$ & $2,858.3$ & $2,828.9$ & $2,948.6$ & $3,123.9$ & $3,132.4$ \\
\hline \multicolumn{6}{|l|}{ Exchange rates (period averages) } \\
\hline Malagasy francs per SDR & $7,016.1$ & $7,381.7$ & $8,585.8$ & $8,934.0$ & $8,385.8$ \\
\hline Malagasy tranes per U.S. dollar & $5,090.9$ & $5,44 !-4$ & $6,283.8$ & $6,773.3$ & $6,587.2$ \\
\hline \multicolumn{6}{|l|}{1 Including official tranfers. } \\
\hline \multicolumn{6}{|l|}{${ }^{2}$ End of period. } \\
\hline \multicolumn{6}{|l|}{${ }^{3}$ Including project gtants. } \\
\hline \multicolumn{6}{|l|}{${ }^{4}$ Including official transfers. } \\
\hline In weeks of imports of goods and services. & & & & & \\
\hline After debt relief. & & & & & \\
\hline
\end{tabular}


Madagascar: Social and Demographic Indicators ${ }^{1}$

Land area (square kilometers)

581,540

Population

Total (in millions) (2001)

Urban population (percent of total)

30.0

Population density (people per sq. $\mathrm{km}$.)

26.7

Population density, rural (people per sq. km. of arable land) (1998)

407.6

Population growth (annual percentage)

Life expectancy at birth (years) (2001)

Overall

Women

Men

Crude birth rate (per 1,000 )

Crude death rate (per 1,000)

Infant mortality rate (per 1,000) (2001)

\section{Education}

Illiteracy rate, adult total (percentage of people over 15) (2001)

Primary education, pupils (in thousands) (1998)

Secondary education, general pupils (in thousands) (1997)

Secondary education, vocational pupils (in thousands) (1992)

Primary school enrollment (percentage of relevant age group) (2001)

Secondary school enrollment (percentage of relevant age group)

Tertiary school exrollment (percentage of relevant age group) (1995)

\section{Health}

Hospital beds (per 1,000)

Physicians (per 1,000)

Safe water (percentage of population with access)

Sanitation (percentage of rural population with access)

Child immunization (under 12 months, percent)

DPT

Measles

Sources: CD-ROM of World Bank, World Development Indicators, 2001; and Malagasy authorities.

${ }^{1}$ Data are for 1999, unless otherwise indicated. 


\section{RECENT ECONOMIC DEvelopments and POLICIES ${ }^{1}$}

1. After several decades of decline in per capita GDP, Madagascar experienced, over the 1997-2001 period, high growh rates as a result of significant progress in macrocconomic stabilization and structural reforms, accompanied by substantial inflows of foreign direct investment and external assistance. Over this period, the growth tate of real GDP averaged 4.6 percent, while inflation generally remained below 10 percent (Figure 1). The incidence of poverty declined from 73 percent to 69 percent of the population, with most gains occurring through a reduction of urban income poverty, while the nural poverty head count remained stable. External sector developnents were favorable, with export earnings doubling over the five years, spurred by the expansion of activity in the export processing zone (EPZ) exports and high intemational vanilla prices. International reserves also increased sharply, reflecting, in part, accelerated inflows of foreign direct investment since 1999.

\section{A. Real Sector}

2. Real GDP growth in 2001 was 6 percent, continuing the trend of sustained increase in per capita real GDP began during the period 1997-2000. The secondary and tertiary sectors were the main sources of growth. The value added of the secondary sector, which accounts for only 13.3 percent of output, increased by 7.6 percent in 2001 , following an arnual average increase of 5 percent over the $1997-2000$ period. The value added of the tertiary sector, which accounts for 52.3 percent of output, grew by 6.1 percent in 2001 , after an average growth rate of 5.5 percent over the last four years. The primary sector, with slower growth and, therefore, a gradually declining share of real value added, grew by 4 percent in 2001.

3. Agriculture accounts for about 55 percent of real value added in the primary sector and employs more than 80 percent of Madagascar's economically active population. Main agricultural products are rice and cassava (for domestic consumption), coffee, cloves, and vanilla (export products), and sugar cane and cotton (industrial products). Output fell in 2000 because of cyclone damages, but recovered by 5.5 percent in 2001 .

4. While the secondary sector accounts for a relatively small share of the total value added, its share increased to 13.3 percent in 2001 from 12.4 percent in 1997. The sector is composed of five main branches of manufacturing activities: food processing, wood and byproducts, textiles and clothing, the metal industry, and public utility services (including electricity and water). The sector bas grown steadily in recent years due to the expansion of activity in the EPZ, established in $1989 .{ }^{2}$ By end-2001, there were 149 firms in the EPZ,

'Prepared by Cemile Sancak.

${ }^{2}$ The EPZ benefits from several fiscal incentives, including a reduced rate on the corporate income tax (CIT); tax holidays from the CIT, ranging from 2 to 15 years depending on the 
employing more than 120,000 people (one-third of the secondary sector) and covering diverse activities, including the textile industry and information processing. ${ }^{3}$

5. The growth of the tertiary sector over the last several years stemmed from the accelerated growth of the secondary sector. For example, the transport sector, which represents 33 percent of the value added in the tertiary sector, experienced an annual average real growth rate of 5.8 percent over 1997-2001, spurred by increased activity in the secondary sector. Construction, which accounts for about 3 percent of the tertiary sector's real output, grew at an annual average growth rate of 11.6 percent over 1997-2001. The tourism sector, with growth rates of over 14 percent a year in recent years, has also been one of the more dynamic sectors of the economy.

6. Domestic savings increased to 12.3 percent of GDP in 2001 from 7.8 percent of GDP in 2000 , as private savings increased to 12.5 percent from 5.3 percent-a gain that was partly offset by the decline of public savings. Over the same period, overall investment rose by 0.5 percentage point of GDP to 15.5 percent of GDP in 2001 , on account of rising public investment (Figure 2).

7. The decline in the average rate of inflation from 11.9 percent in 2000 to 7.4 percent in 2001 is attributable to a number of factors, including favorable agricultural production, the appreciation of the exchange rate, the large imports of rice (the main staple food), and a decline in money velocity, reflecting increased confidence by the business community.

\section{B. Public Finance}

8. Fiscal performance in 2001 was satisfactory in the first half of the year, but revenue in the second half of the year fell substantially short of target, owing largely to weaknesses in customs administration. For the year, budgetary revenue reached 10 percent of GDP, compared with a revised program target of 11.9 percent (Figure 3 ). Contrary to the normal seasonal trend, customs revenue in the second half of the year was considerably lower than in the first half. There are indications that the deteriorating performance was attributable to the continuing disorganization of customs services at secondary ports, as well as some exceptional exemptions granted in the run-up to the December 2001 presidential elections. Despite the revenue shortfall, the overall deficit, on a commitment basis and excluding grants, was contained at 8.1 percent of GDP, as against the program target of 9.9 percent, as government expenditures were 2.8 percent of GDP lower than programmed. This reflected a substantial shortfall in capital expenditure relative to program by 2.8 percent of GDP and lower-than-anticipated costs of structural reforms, such as the severance pay in connection with the privatization of public enterprises. Current expenditures were only marginally higher

type of enterprise; a reduced dividend distribution tax; and exemptions from import duties and taxes, including excises.

${ }^{3}$ Most firms are in the textile and apparel-manufacturing sector. 
than programmed, as a shorffall in expenditures on goods and services, including those financed by debt relief under the Initiative for Heavily Indebted Countries (HIPC Initiative), was offset by significant election-related overruns of expenditures through the special fund of the presidency (estimated at 0.6 percent of GDP). In mid-July 2002, the new government commissioned the State Inspectorate General to conduct an audit of both the HIPC Initiative financed expenditures and the use of the presidential special fund in 2001 .

9. External budgetary financing was about 1 percent of GDP lower than programmed, as (i) the disbursement of the second tranche of the World Bank's second structural adjustment credit (SAC II) (US $\$ 30$ million) was delayed until January 2002 due to the late selection of a winner of the tender for the telecommunication company, TELMA, and (ii) the disbursement of a tranche of the European Union's structural adjustment assistance was postponed because of delays in the negotiations of conditionalities. With privatization receipts also lower than programmed by FMG 90 billion ( 0.3 percent of GDP), as proceeds of the sale of certain assets of the petroleum company were delayed until 2002, bank financing of the government exceeded the revised program by 0.7 percent of GDP.

\section{Financial Sector}

10. Madagascar's banking system consists of the Central Bank of Madagascar (BCM), six privately owned commercial banks, a microfinance network, and two insurance companies. The BCM is responsible for the implementation of monetary policy. The Banking and Financial Supervision Commission (CSBF) supervises and regulates all financial services, with the exception of the insurance companies, which are regulated by the Ministry of Finance and Economy. The BCM's main monetary policy instruments are the required reserve ratio and the treasury-bill auction system, both of which influence the liquidity of the banking system. In addition, the BCM uses the discount rate to signal changes in its monetary policy stance. As average inflation declined to 7.4 percent in 2001 from 11.9 percent in 2000 , interest rates on treasury bills began to fall (Figure 4). The central bank's base rate (TD) was cut in June 2001 from 12 percent to 10.5 percent and further in October 2001 to 9 percent, while the reserve requirement was maintained unchanged at 24 percent for demand deposits and 3 percent for time deposits. With a view to promoting credit expansion in favor of the private sector, which had suffered serious losses during the crisis, the central bank decided to lower the required reserve ratio on demand deposits to 18 percent and on time depesits to 2 percent on October $21,2002$.

11. Broad money grew on average by 16.6 percent during the period 1997-2000. It increased by 24.4 percent in 2001 , reflecting a surge in both net foreign assets of the banking system and net domestic assets. While net foreign assets grew by 15.4 percent of initial money stock (up from 12.2 percent in 2000), owing to higher foreign direct investment and export earnings, net domestic assets rose by 16.6 percent of initial money stock, on account of a sharp increase in the domestic financing requirement of the government; this was partly offset by the decline in credit to the economy, as strong profits reduced the borrowing needs of exporting firms, which are traditional users of bank credit. 
12. The monetary autborities continued to pursue a flexible exchange rate policy; the central bank intervened on the exchange market to achicve external reserve objectives and to minimize temporary exchange rate fluctuations.

13. The authorities have adopted measures to enhance the soundness of the banking and financial sector ${ }^{4}$ based on the recommendations of the 1999 MAE technical assistance mission. Accordingly, the CSBF issued several instructions in 2000 and 2001; these limit insider lending to 10 percent of capital, require all banks to implement a permanent internal audit system subject to systematic review by the CSBF, set prudential limits for bank participation in nonbanking activities, and reduce the regulatory ceiling on lending concentration from 40 percent to 30 percent of capital. The CSBF also adopted regulations and supervisory standards for credit unions and microfinance institutions not previously covered, including a new licensing requirement, effective July 2001.

\section{External Sector}

14. The external sector benefited from favorable conditions in key commodity export markets and a robust expansion of activity in the EPZ in 2001. The current account deficit, including grants, narrowed to a record low of 1.3 percent of GDP, while the trade balance moved to a small surplus for the first time since 1987 (Figure 5). Exports were the key factor in this development as they expanded by more than 20 percent. Led by favorable international market prices, vanilla exports tripled, while clove exports doubled.

Manufactured exports from the EPZ enterprises also contributed to export growth, as they rose by 8 percent in value in the year. EPZ firms profited from the favorable impact of the U.S. African Growth and Opportunity Act (AGOA), as textile exports to the United States doubled in 2001 . Imports, on the other hand, increased only by 6 percent in value, as equipment goods and food imports grew modestiy and petroleum imports fell, while oil prices declined.

15. The favorable external conditions led to an increase of net foreign assets of the central bank by SDR 77 million to SDR 214 million in 2001. At the end of the year, the gross foreign reserves were equivalent to 14.4 weeks of imports of goods and nonfactor services, up from 10 weeks at end-2000. The increase in gross international reserves reflects the improvement in the current account and strong foreign direct investment and inflows of external assistance, both for budgetary and balance of payments support and project financing. Foreign direct investment, while still modest, reached 2 percent of GDP in 2001, increasing by more than one-third. The foreign-financed component of the public investment program amounted to 4 percent of GDP, with grants accounting for about 60 percent of the total. External budgetary and balance of payments support amounted to 1.3 percent of GDP, including an SDR 22 million purchased from the Fund.

${ }^{4}$ The ratio of nonperforming loans to total loans increased from 8.4 percent in 2000 to 10.3 percent in 2001. 
16. Reflecting the positive overall balance of payments, the Malagasy franc appreciated by about 8 percent in nominal effective terms and by 10 percent in real effective terms during 2001. Despite the appreciation of the currency, unit labor costs remained highly competitive."

17. After having reached the decision point of the enhanced HIPC Initiative in December 2000, multilateral creditors, including the African Development Bank, IDA and the IMF, delivered interin debt relief in 2001 amounting to SDR 18.8 million. Paris Club creditors provided Cologne terms flow-of-debt relief beginning March 2001, in an amount equivalent to SDR 55.8 million for the year. They are expected to deliver Cologne stock-of-debt relief once Madagascar attains the completion point. The authorities are in bilateral negotiations with some Paris Club creditors in order to obtain debt relief beyond Cologne terms. Madagascar is also negotiating with non-Paris Club creditors to reschedule current arrangements on terms at least comparable to those of the Paris Club. In 2001, rescheduling agreements were concluded with the Saudi Fund for Development and a commercial bank from Hong Kong SAR. The authorities also reached an agreement with Russia on the restructuring of post-cutoff-date debt in December 2001 and signed a protocol of partial cancellation of the debt owed to China in November 2001. Provided the enhanced HIPC assistance agreed at the decision point is delivered, the net present value of debt-to-exports ratio would fall from 259 percent at end-2000 to 183 percent at end-2001.

18. In recent years, Madagascar has liberalized and simplified its external trade regime. Since October 2000, the country has been a member of the Common Market for Eastern and Southern Africa (COMESA). Also, since early 2000 , it has had a preferential tariff agreement with Comoros and Mauritius; ${ }^{6}$ both agreements provide for a 100 percent tariff reduction. In 2000, Madagascar adopted a five-rate, non zero external tariff structure with a maximum tariff of 30 percent, consistent with the commitment under the Regional Integration Facilitation Forum (RJFF). The number of products subject to the 30 percent rate was reduced further in 2001, in line with commitments under the RIFF. As of 2001, Madagascar has an open trade regime. According to the Fund's overall trade restrictiveness index, Madagascar is rated 3 on the 10 -point scale of restrictiveness ( 10 indicating the most restrictive). In 2001, Madagascar's average tariff rate (including the statistical tax on imports and stamp duties) was 20 percent, with very few nontariff barriers.

${ }^{5}$ See discussion in Section $\mathrm{II}$ of this issues paper.

${ }^{6}$ At present, nine countries are members of the COMESA free trade area: Djibouti, Egypt, Kenya, Madagascar, Malawi, Mauritius, Sudan, Zambia, and Zimbabwe. Madagascar's trade with Mauritius is significant, with exports and imports from Mauritius accounting for 4 percent and 10 percent of the total, respectively. However, trade with COMESA countries, other than Mauritius, is negligible. 


\section{E. Structural Reforms}

19. In 2001, the authorities implemented a number of structural reforms in the area of budgetary management, tax administration, and privatization. Fund technical assistance was instrumental in improving public expenditure management, with a view to preparing monthly "flash" reports on a timely basis. New computerized systems were installed in all 22 main treasury offices, and became operational in November 2001. The computerized customs information system (ASYCUDA 2.7) was installed in the secondary ports, but the upgrade to version $3++$ was delayed. A UN Conference on Trade and Devclopment (LNCTAD) technical assistance mission to secure its installation is expected shortly.

20. The authorities continued to implement their comprehensive public enterprise privatization program, concluding the sale of assets (storage facilities) of the state petroleum company, SOLIMA, and launching the tender for the telecommunications company, TELMA; the winner of the tender was selected in December 2001. In mid-2002, the authorities decided to place Air Madagascar under a management contract with an internationally recognized foreign firm, in order to improve its efficiency and pave the way for a future privatization. They also decided to open up the capital of the state cotton company, HASYMA. 


\section{Economic and Social IMPact of The Political Crisis?}

\section{A. The Political Crisis, January-July 2002}

21. The political crisis started following the first round of presidential elections on December 16, 2001. Mr. Ravalomanana, then Mayor of Antananarivo and the leading challenger against the incumbent President, Mr. Ratsiraka, contested the results announced by the High Constizutional Court (HCC), according to which Mr. Ravalomanana received 46.21 percent of the vote and Mr. Ratsiraka received 40.85 percent. The support committee for Mr. Ravalomanana, observing the polling and having separately counted the votes, argued that Mr. Ravalomanana in fact won the election by an absolute majority, rendering a second round of elections unnecessary. Mr. Ratsiraka's insistence on a second round of elections triggered daily mass demonstrations and a general strike, starting in late January in Antananarivo, by the supporters of Mr. Ravalomanana. Mr. Ravalomanana proclaimed himself President on February 22, appointed a new government, and took over all ministries in the capital, while Mr. Ratsiraka set up his seat of government in Toamasina (Tamatave). At the same time, Mr. Ratsiraka's supporters blockaded all roads from the coastal areas to the central plateau and began blowing up bridges. In early March, Mr. Ratsiraka's government appointed a new governor of the central bank based in the Toamasina branch. With the central bank management split, foreign depositories froze the external reserves of the central bank, preventing the payment of external obligations, as well as the functioning of the interbank foreign exchange market.

22. Mediation attempts under the auspices of the Organization of African Unity (OAU) and the United Nations led to an agreement on April 18,2002 in Dakar, Senegal. After a recount of the first-round votes, as stipulated by the agreement, the HCC on April 29 declared Mr. Ravalomanana winner of the elections with 51.46 percent of the vote, compared with the 35.90 percent obtained by Mr. Ratsiraka; Mr. Ravalomanana was officially inaugurated as President on May 6. Following the recount of the first-round votes, Mr. Ravalomanana's government received growing domestic support. With the bulk of the military shifting support to Mr. Ravalomanana, his government was able to take control of the coastal cities of Tuléar and Majunga in mid-June and of the port of Diego Suarez at the beginning of July. By early July, most countries had officially recognized Mr. Ravalomanana's government. The political crisis ended when Mr. Ratsiraka left Toamasina for France in July, with Mr. Ravalomanana in control of the whole country; road blockades were dismantled and the free flow of people and goods through the country was reestablished. The foreign exchange market reopened in late July. This chronology of events is summarized in Box 1.

${ }^{7}$ Prepared by Cemile Sancak. 
Presidential elections

Box 1. Chronology of Events

December 16, 2001. First round of presidential elections.

December 23, 2001. The High Constitutional Court (HCC) rejects the petition by Ravalomanana supporters to compare the vote count by the Ministry of the Interior and that of the KMMR (support committee of Mr. Ravalornanana); the petitioners claira that Mr. Ravalomanana attained more than 50 percent of the popular vote in the first round of elections.

January 25, 2002. The HCC announces that Mr. Ravalomanana received 46.21 percent of the vote and Mr. Ratsiraka received 40.85 percent.

\section{Protests and dual governments}

Late-January-February 2002. Massive protests in the capital organized by Mr. Ravalomanana"s supporters

January 30, 2002. Mr. Ravalomanana calls for a general strike in Antananarivo; daily central bank operations cease; interbank foreign exchange and treasury bill markets close.

February 2002. Diplomatic initiatives by the Association of Francophone Parliamentarians, the Organization of African Unity (OAU), the Indian Ocean Commission and Mauritius fail to end the crisis. February 22, 2002. Mr. Ravalomanana declares himself the President of the Republic and takes over all ministries in the capital.

February 26, 2002. Mr. Ravalomanana appoints Mr. Sylla as the Prime Minister and nominates a government, while Mr. Ratsiraka continues to act as the President from his stronghold of the coastal city of Toamasina. Strikes in the capital end.

February 28, 2002. Mr. Ratsiraka declares martial law in the capital, which is not respected.

February-March 2002. Ratsiraka supporters begin setting up roadblocks throughout the country and destroy bridges to isolate Antananarivo.

March 4, 2002. Central bank headquarters reopen.

March 7-8, 2002. Mr. Ratsiraka's government fires the governor of central bank and appoints a new interim governor, who controls the Toamasina branch. Foreign depositories freeze external reserves of the central bank.

April 18, 2002. Mr. Ravalomanana and Mr. Ratsiraka sign an agreement in Dakar, Senegal, under the auspices of the OAU and the United Nations, stipulating also a recount of the first-round vote.

April 29, 2002. After a recount of the vote, the HCC declares Mr. Ravalomanana the winner of the elections with 51.46 percent of the vote against the 35.90 percent obtained by Mr. Ratsiraka.

May 6, 2002. Mr. Ravalomanana is officially inaugurated as the President of the Republic and confirms Mr. Sylla as Prime Ministet.

May 7, 2002. Four governors (of Tulear, Diego Suarez, Toamasiza, and Majunga) loyal to Mr. Ratsiraka declare their provinces sovereign and independent.

May 31, 2002. The govemment of Ptime Minister Sylla launches a military offensive to take control of the provinces loyal to Mr. Ratsiraka.

\section{Recognition of Mr. Ravalomanana}

May 2002. Switzerland and Norway recognize Mr. Ravalomanana as the President of Madagascar.

June 19, 2002. Mr. Ravalomanana gains control of Tuléar and Majunga.

June 26, 2002. The United States recognizes Mr. Ravalomanana as President.

July 2, 2002. Military units loyal to Mr. Ravalomanana enter Diego Suarez.

July 3, 2002. The French Minister of Foreign Affairs visits Antananarivo and meets with Mr.

Ravalomanana, implicitiy sigualing recognition by France.

July 5, 2002. Mr. Ratsiraka leaves Toamasina for France.

July 8, 2002. Toamasina falls without resistance; Mr. Ravalomanana controls the whole country.

July 11, 2002. European Union countries recognize Mr. Ravalomanana's government. 


\section{B. Economic Impaet of the Political Crisis}

23. The political crisis engendered a sharp downtum in economic activity. The economic cmbargo on a large part of the central plateau, beginning in early February, and the resulting disruption of transportation led to a significant reduction in domestic and external trade. Output losses due to the crisis were concentrated in the transport, export processing zone (EPZ), and tourism sectors. Real GDP is projected by the government statistical agency, INSTAT, to decline by 12 percent in 2002. The consumer price index increased by 21 percent in the first five months of 2002, mainly as a result of shortages of fuel and other necessities, such as food products and soap. Income poverty is estimated to have risen by as much as 6 percent, up from 69 percent of the population in 2001 to 75 percent.

\begin{tabular}{|c|c|c|}
\hline \multicolumn{3}{|c|}{$\begin{array}{l}\text { Box 2. Economic Impact of the Political Crisis } \\
\text { (annual percentage change) }\end{array}$} \\
\hline & $\begin{array}{l}2001 \\
\text { Actual }\end{array}$ & $\begin{array}{c}2002 \\
\text { Projection }\end{array}$ \\
\hline Real GDP & 6.0 & -11.9 \\
\hline Primary sector & 4.0 & -1.4 \\
\hline Secondary sector & 7.6 & -25.1 \\
\hline Tertiary sector & 6.1 & .12 .5 \\
\hline $\begin{array}{l}\text { Consumer Price Index } \\
\text { (average) }\end{array}$ & 6.9 & 15.3 \\
\hline
\end{tabular}

24. The political crisis had a relatively mild adverse impact on primary sector production, compared with the impact on the secondary and tertiary sectors of the economy (see Box 2). The expected decline in primary sector output in 2002 results from a decline in forestry output, partially offset by agriculture output growth of 0.8 percent. The decline in primary sector activities is partly expiained by disruptions to harvesting due to the unavailability of transportation and lack of credit to pay field laborers. In addition, several agro-business enterprises, such as the cotton company, HASYMA, ceased operations owing to cash constraints. While the volume of agricultural production remained relatively stable in real terms during the crisis, producer prices for some food crops, such as rice, declined by up to 50 percent in isolated communities as a result of the sharp increase in transport costs and difficulties in delivering products to markets. At the same time, the prices of imported staple goods, such as salt, sugar, vegetable oil and lamp oil, increased sharply until May. Consumer prices declined from June to September, after the free movement of people and goods had been reestablished. 
25. The political crisis had its largest impact on the secondary sector, where output is expected to plummet by 25.1 percent in 2002 . Road blockades prevented the supply of essential inputs, including fuel and raw materials, for most manufacturing industries located in the central plateau. In addition, companies producing for the domestic market faced weaker demand, prompting them to curtail production and lay off workers. It is estimated that, for EPZ companies, which are mainly involved in apparel production for export markets, output will fall by about 70 percent in 2002 , following a 40 percent increase in 2001. EPZ firms, unable to meet foreign orders, shut down operations, with the exception of a few in high-value-added production, which were able to ship products by air, and of a few located in coastal areas. Most companies shut down their plants, temporarily laying off an estimated 100,000 EPZ employees. Since a number of foreign orders have been lost, by midOctober 2002, only 49 about $150 \mathrm{EPZ}$ companies had partially resumed operations, accounting for some 20,000 workers. The EPZ companies are, as a group, expected to operate at significantly reduced ( 35 percent or less) capacity until spring 2003 , when foreign orders and production are expected to pick up. ${ }^{8}$

26. The tertiary sector was also hard hit by the political crisis, with an expected decline in output of 12.5 percent for the year as a whole, compared with an increase of 6.1 percent in 2001. Transportation was one of the most affected sectors, as 90 percent of the trucking fleet was virtually immobilized by the roadblocks, damaged bridges, and fuel shortages. 'The severe shortage of fucl led to a sharp increase in petroleum prices on the black market of as much as 500 percent across the country. ${ }^{10}$ Air Madagascar stopped most internal and external flights, as did most foreign carriers for security reasons. Commercial activity also declined substantially following the decline in secondary and tertiary sector output. Since about 55 percent of Madagascar's electricity output is utilized by industries and businesses, electricity output fell during the crisis as economic activity slowed. In the electricity sector, two acts of sabotage cut power to Antananarivo on two occasions. The public electricity company, JIRAMA, also had collection difficulties as local governments and universities could not pay their electricity and water bills. Tourism was brought to a halt during the crisis; international travel to Madagascar for tourism is estimated to have declined by 95 percent.

27. The banking sector continued operations throughout the crisis and ensured the continuity of the payment's system. The quality of the commercial bank's loan portfolio

${ }^{8}$ As new foreign orders are received, there is usually a six-month lag between customer orders and production phases for EPZ companies.

${ }^{9}$ In addition to the economic embargo, Cyclone Kesiny in February caused hundreds of landslides that blocked key roads and damaged several bridges in the eastern part of the country.

${ }^{10}$ The official posted prices did not change during the crisis, but there was no petroleum to sell at these prices. 
deteriorated, as the share of nonperforming loans rose from 10.3 percent at end -2001 to 14.0 percent at end-August 2002 . Until October 23,2002 , when the treasury bill market reopened, all treasury bond holdings, including those of the commercial banks, were automatically rolled over. As the interbank foreign exchange market was closed from February to July, foreign exchange operations were severely curtailed; they did however perform some transactions on a "netting" basis. Microfinance institutions bave reported lower savings and credit repayment rates following the crisis. The telecommunications sector experienced a small decline in output during the crisis but is expected to fully recover in the last months of 2002 , compensating for most of that decline.

\section{Social Impact of the Political Crisis}

28. The crisis had a particularly strong impact on poor families and vulnerable groups. Three groups in particular experienced a sharp decline in their standard of living: farmers in the rural areas, the newly unemployed in the formal sector, and the extremely poor in the informal sector in the urban areas. In the rural areas, farmers, especially those isolated from the markets, experienced a decline of up to 50 percent in household income, as a result of a significant drop in producer prices and a dramatic increase in fuel and transport costs. ${ }^{11}$ in urban areas, reduced production and the temporary shutdown of companies resulted in loss of jobs for about 150,000 mostly low-skilled workers in the formal sector. The loss of income in urban formal sector income also led a drop in demand for informal sector operators.

Consequently, the extremely poor, who are primarily involved in informal sector activities, such as petty trade and day work in the construction industry, were particularly affected by the crisis.

29. In addition to the loss of income, the sharp increase in the prices of a number of essential goods further reduced the purchasing power of these groups. On the basis of simulations made using the household survey data collected during the crisis, the United Nations Development Program (UNDP) bas estimated that income poverty increased by as much as 6 percent since 2001 and now affects 75 percent of the population. In addition, the World Bank reports that, in the February-August period, school dropout rates increased significantly, reaching 14 percent, while visits to health care centers declined by 36 percent in rural areas and 14 percent in urban areas. Both rural and urban families have reported decreased food consumption, which is likely to further increase malnutrition rates for children under 5 years of age.

${ }^{11}$ Source: INSTAT. 


\section{External Competitiveness ${ }^{12}$}

\section{A. Introduction}

30. Since the establishment of an export processing zone (EPZ) regime in 1989, exports have assumed an increasingly important role in Madagascar's economic development. And, as Madagascar's exports have become more diversified, the maintenance and enhancement of international competitiveness have assumed an increased importance. Over the period mid1999 to 2001, concern over a possible deterioration in competitiveness developed as the nominal and real effective exchange rates of the Malagasy franc were appreciating (by about 18 and 33 percent respectively between June 1999 and December 2001, Figure 6). Motivated by the question of whether the appreciation reflected an equilibrium movement or an incipient misalignment, and recognizing that the measurement of external competitiveness cannot rely on a single approach, the staff has been monitoring Madagascar's export performance and various measures of competitiveness.

31. This section provides a short survey of the findings derived from three different approaches to the measurement and assessment of competitiveness. ${ }^{13}$ These include econometric modeling of the fundamental determinants of the equilibrium real effective exchange rate, comparative labor cost analysis, and an analysis based on a constant-marketshare (CMS) decomposition analysis. In short, the results from all three approaches suggest that Madagascar remains broadly competitive, despite the recent current appreciation, and that there is no evidence of a detrimental exchange rate misalignment.

32. These general conclusions tend to be supported by Madagascar's recent export performance. Receipts for exports of goods and nonfactor services have increased steadily since 1996, rising from about 20 percent of GDP in 1996 to over 30 percent in 2001, and the volume of exports increased in every year from 1996 to 2001 . The current account deficit (excluding official transfer) in relation to GDP narrowed from about 8 percent of GDP in 1997-98 to 5.7 percent in 2000, and further to 1.7 percent in 2001. Prior to 2002, Madagascar was reasonably successful in attracting numerous foreign investors, partially through an ambitious program of privatization of state enterprises, but in particular through its EPZ regime, especially in the textile and apparel manufacturing sector. Private capital inflows increased from 0.2 percent of GDP (SDR 4 million) in 1994 to over 2 percent of GDP (SDR 50 million) in 2000 (Figure 7).

33. This section is organized as follows. The next subsection highlights the results of an econometric analysis of the fundamental determinants of the real exchange rate and an assessment of misalignment. A comparative analysis of trends in Madagascar's labor costs

12 Prepared by Messrs. John Cady and Jie Liu (both AFR).

${ }^{13}$ This section will summarize key findings rather than provide details. Another avenue for disseminating the detailed analyses will be found, perhaps through the publication of Working Papers. 
vis-à-vis specific competitor countries is reported in Subsection C. Subsection D outlines the application of CMS analysis to Madagascar's export growth during the period 1991-2001. Subsection E concludes.

\section{B. Equilibrium Real Exchange Rate Assessment}

34. Using econometric methods, the fundamental long-run determinants of the real exchange rate of the Malagasy franc (including the net foreign assets position, terms of trade, taxes on international trade, and investment spending) have been modeled. ${ }^{14}$ Using an estimated long-run equation for the real effective exchange rate, evaluated at trend, or smoothed, values of all independent variables, estimates of the equilibrium real exchange rate have been derived. From these equilibrium estimates and actual values of the real exchange rate, measures of real exchange rate misalignment can be derived. The exercise indicates that the real exchange rate of the Malagasy franc has been significantly overvalued and undervalued for long periods in the past, but that, since 1996, the estimated equilibrium and actual real effective exchange rates have been quite close to each other, exhibiting differences of less than 5 percent. Thus, after taking into account changes in the fundamenta! determinants, the appreciation of the real effective exchange rate between 1999 and 2001 would appear to be consistent with an equilibrium change and indicative of neither misalignment nor a loss of competitiveness.

\section{Relative Labor Cost Analysis}

35. This subsection reports the key findings of a comparison of Madagascar's labor costs in the manufacturing sector since 1967 with a those of a small group of selected competitor countries. ${ }^{15}$ The rationale for exarnining relative labor costs is that labor usually represents the main domestic value-added component of total production costs and thus captures a key underlying determinaut of competitiveness. To the extent that capital and intermediate goods are traded in intemational markets, whereas labor remains largely immobile internationally, labor costs are likely to diverge much more across countries than other costs of production, and, therefore, play an important role in determining the country's overall external competitiveness and in attracting foreign direct investment.

36. The comparison, conducted using U.S. dollars as a common currency, indicates that since 1987 , Malagasy labor costs have been significantly below those in the comparator countries. In 2000, average monthly wages in Madagascar were about $\$ 58$, compared with

14 The paper "The Sustainable Real Exchange Rate for Madagascar: Estimation and Assessment," by John Cady, will shortly be issued as an IMF Working Paper.

15 The comparator countries comprise India, Kenya, and Mauritius. These countries were chosen, first on the basis of having significant textile and apparel industries, and, second, on the availability of labor cost data. The data have been drawn from the United Nations Industrial Development Organization (UNTDO) database, supplemented with labor cost data reported by Malagasy sources over the period 1994-2000. 
countries. In 2000 , average monthly wages in Madagascar were about $\$ 58$, compared with about $\$ 100$ in India and Kenya, and $\$ 271$ in Mauritius (Figure 8). This comparison ignores the effects of labor productivity differentials, an aspect that the staff intends to address in future work using unit labor costs, however, it nonetheless indicates that the level of wages in Madagascar's manufacturing sector tends to be much lower than in some key competitor countries.

\section{Constant Market Share Analysis}

37. This subsection summarizes the results of a constant-market-share analysis of Madagascar's export growth over the period 1991-2001. The CMS decomposition of export growth suggests that Madagascar has become more somewhat competitive between the base year of 1991 and 2001.

38. CMS analysis is a popular, easily applied method for examining a country's export growth. It entails the decomposition of the change in a country's exports between any two time periods into four components: a general growth effect; a commodity composition effect; a market distribution effect; and a residual effect, accounting for all other factors which is usually attributed to change in competitiveness.

39. More formally, the change in exports can be expressed by the following equation:

$\Delta X=\Sigma r X_{i}+\Sigma\left(r_{i}-r\right) X_{i}+\Sigma \Sigma\left(r_{i j}-r_{j}\right) X_{i j}+\left(\Delta X-\Sigma \Sigma r_{i j} X_{i j}\right)$,

where

$r$ is the proportional change in the overall exports of competitor countries;

$r_{i}$ is the proportional change in the overall exports of competitors' exports of good $i$;

$r_{i j}$ is the proportional change in the overall exports of competitors' exports of good $i$ in market $j$;

$X_{i}$ is Madagascar's exports of good $i$; and

$X_{i j}$ is Madagascar's exports of good $i$ in market $j$.

40. The first term on the right-hand side of the equation is generally interpreted as the "general growth effect," measuring the export growth associated with the general increase in world exports; the second term is the commodity composition effect, which is meant to capture the extent to which a country's exports are concentrated in commodity classes with growth rates more favorable than the world average; and the third term is the market distribution effect, which indicates whether the country's exports have been concentrated in markets experiencing relatively rapid growth. These first three effects measure the change in exports that would occur if the country were able to keep constant its shares in the corresponding markets. The final, or competitiveness effect, then accounts for all growth that arises from changing export shares. ${ }^{16}$

${ }^{16}$ The competitiveness effect may embody several influences on the sales of a particular country's exports in foreign markets. On the demand side, these factors could include the following: differential rates of export price inflation, differential rates of quality 
41. CMS analysis has the advantage of being able to account for the extent to which a country's exports are concentrated in commodities and markets that can be considered to be expanding slowly or rapidly, and the nature of the actual expansion of exports in the particular context. This type of analysis may point to a preferred composition and distribution of exports because, presumably, a country will prefer to concentrate its exports in commodities and markets that are rapidly expanding. However, the CMS method does have certain limitations: in particular, the results can be sensitive to the choice of base year and competitor groups.

42. The CMS analysis was conducted over the period 1991-2001 using country trade data available in the UN Commtrade database, ${ }^{17}$ with the key findings summarized below:

Millions of U.S. Dollars

Ratio to Total Export Growth

Total export growth

527.0

1.00

Growth effect

$-14.3$

Commodity effect

$-124.3$

$-0.24$

Market effect

141.7

0.27

Competitiveness effect

523.9

0.99

43. Since the introduction of the EPZ regime in 1989 , there has been significant economic transformation in Madagascar. The structure of exports has shifted from traditional commodity exports, such as vanilla, cloves, and coffee, to shrimp and other fishery products and textiles and apparel. Reflecting these changes, the CMS decomposition suggests that competitiveness increased significantly during the period 1991-2001, starting in 1992, and accounting for almost all ( 99 percent) of the net increase in exports over the complete reference period. The growth and commodity effects are estimated to have diminished export

improvement and the development of new exports, differential rates of improvement in the efficiency of marketing or in the terms of financing the sale of export goods, and differential changes in the ability to promptly fill export orders. On the supply side, the factors could include the following: differential rates of monetary inflation, differential growth rates of available productive factors and the responsiveness of export supply to the domestic supply of these factors, and differential rates of productivity increases.

${ }^{17}$ Available through the World Bank's World Integrated Trade Solution (WITS) system. The database contains detailed annual data, starting in 1962, on the value of imports and exports across the ten broad, one-digit SITC categories and across various country markets. 
growth by 3 and 24 percent, respectively, while the market effect remained positive, contributing some 27 percent to the total export growth (Figure 9).

\section{E. Conclusions}

44. The research findings summarized in this section, all tend to support the notion that Madagascar remains competitive, despite the currency appreciation from 1999 to 2001 . This view is supported by Madagascar's recent export perfonnance and also tends to be shared by the managers of textile and apparel manufacturing enterprises operating in Madagascar's EPZ. In general, they appreciate the quality and productivity of Malagasy labor, indicating that shortfalls in the hourly productivity of Malagasy workers vis-à-vis the best garment workers in the world are more than compensated for by the lower wages prevailing in Madagascar. Most EPZ operators, and especially those in the apparel industry, consider Madagascar an attractive place to invest, despite factors that they citc as hurting competitiveness, including poor public infrastructure, high telecommunications costs, operational inefficiencies at ports and airports, and an overly bureaucratic regulatory and tax system, compounded by corruption.

45. In the year to July 2002 , following resolution of the 2002 political crisis (see Section II), the Malagasy franc depreciated by over 11 percent in nominal terms, reversing some of the appreciation experienced over the period 1999-2001, boosting competitiveness. Nevertheless, the crisis has not enhanced Madagascar's reputation for political stability and could represent a significant negative factor influencing Madagascar's overall competitiveness. EPZ production and exports have been slow to recover since July 2002 , with only one-third of EPZ operators having at least partially resumed their operations by October. Thus, it still remains to be seen whether the 2002 crisis has permanently driven away existing and potential foreign investors. 
Figure 1. Madagascar: Selected Economic and Financial Indicators, 1997-2001
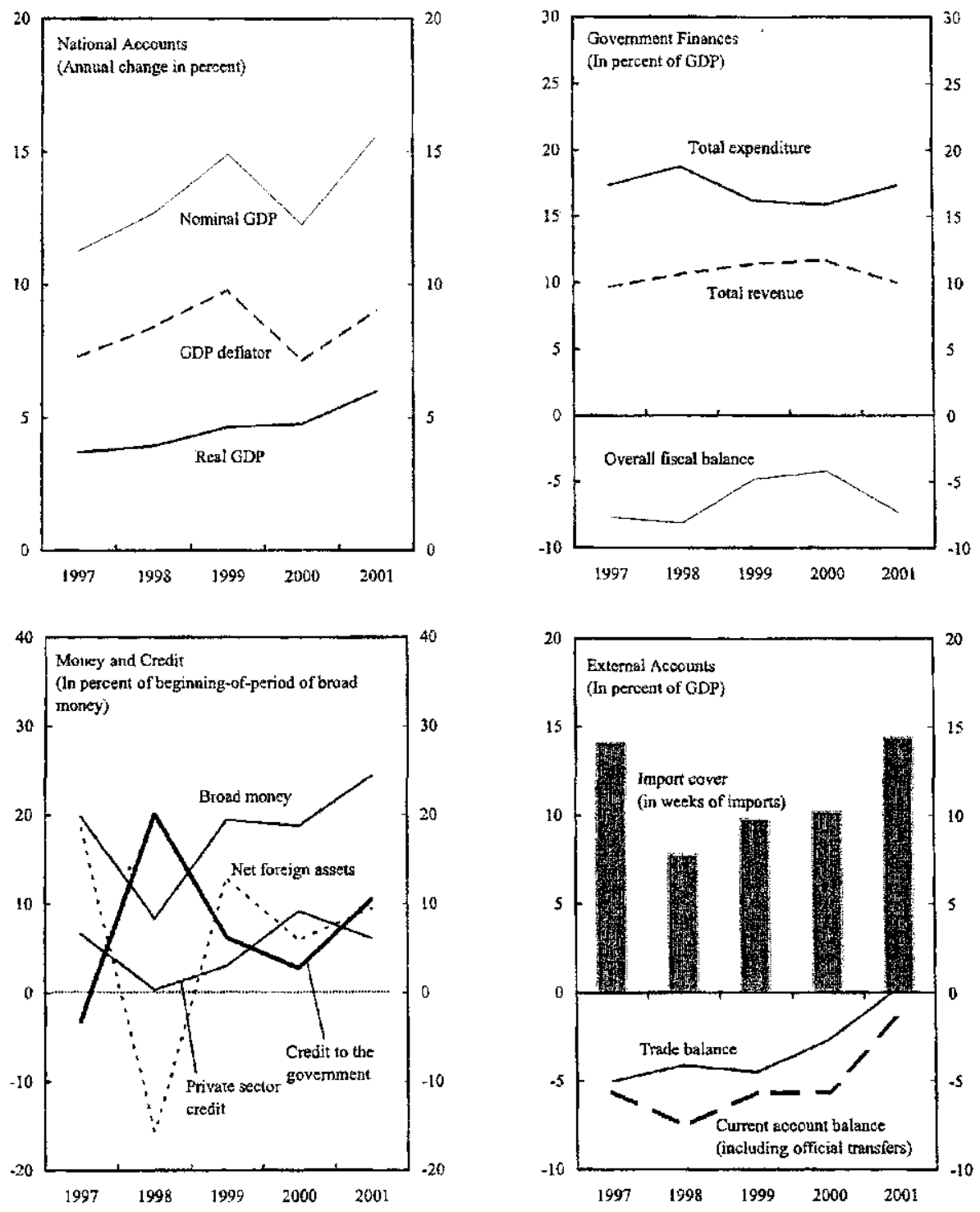

Source: IMF, African Department. 
Figure 2. Madagascar: Real Sector Developments, 1997-2001
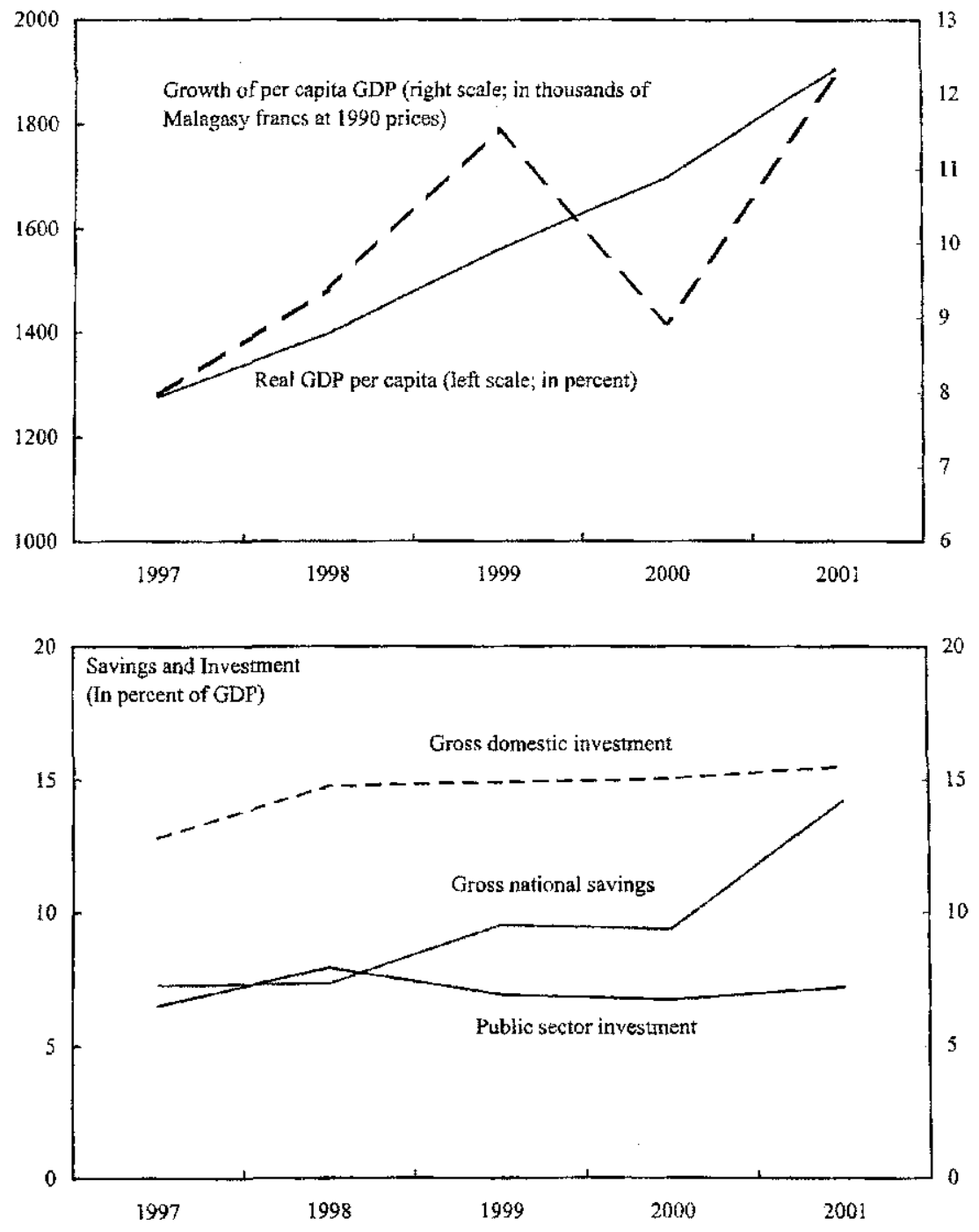

Source: IMF, African Department. 
Figure 3. Madagascar: Fiscal Sector Developments, 1997-2001
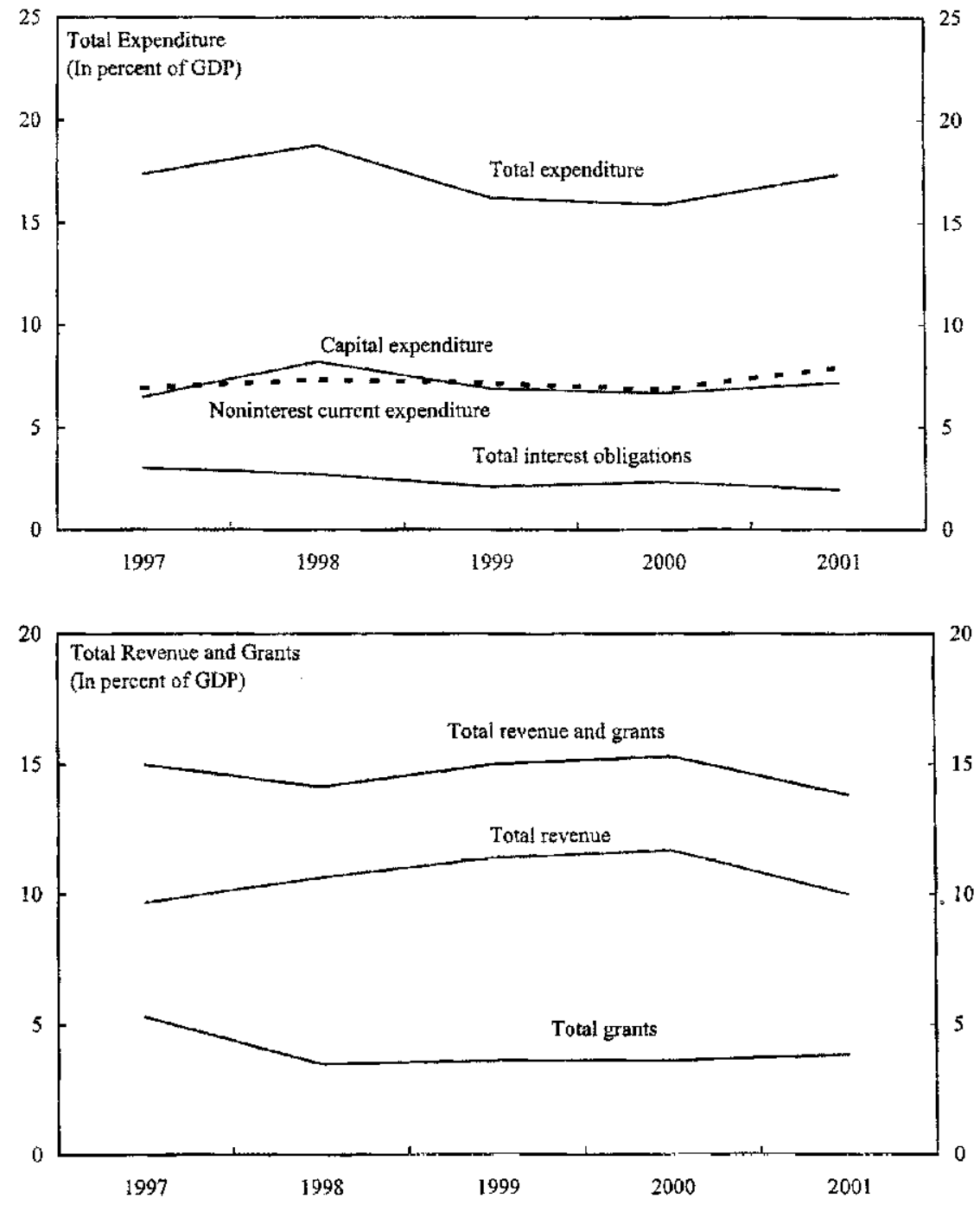

Source: IMF, African Deparment. 
Figure 4. Madagascar: Money, Consumer Prices, and Treasury Bill Yields, 1997-2001 ${ }^{1}$

(In percent)

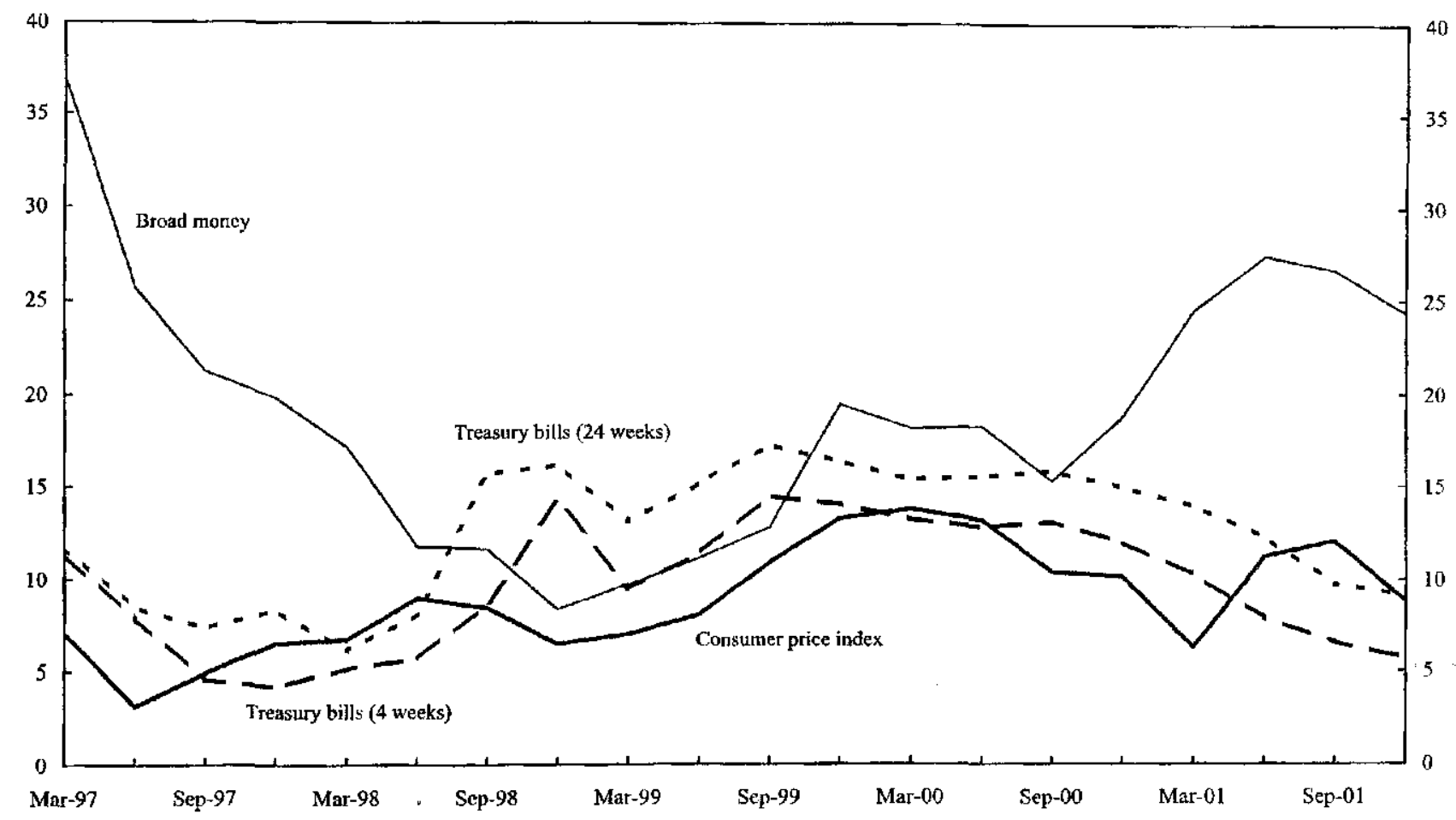

Source: Madagascar authorities.

${ }^{1}$ Data for broad moncy and the consumer price index are year-over-year growth rales. 
Figure 5. Madagascar: External Sector Developments, 1997-2001
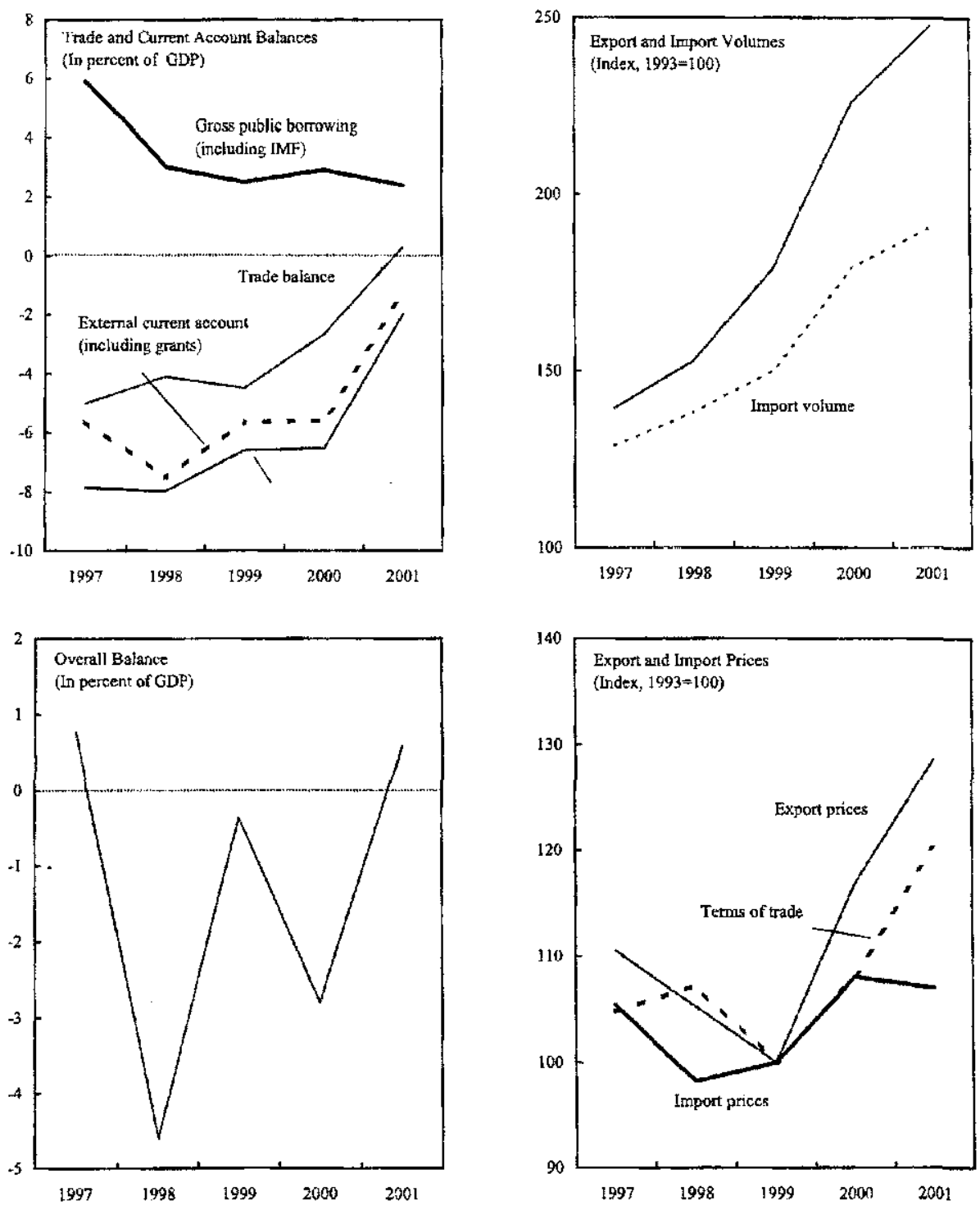

Source: IMF, African Department. 
Figurc 6. Madagascar: Real and Nominal Exchange Rates, January 1990 - August 2002 (Average 1990 $=100$ )

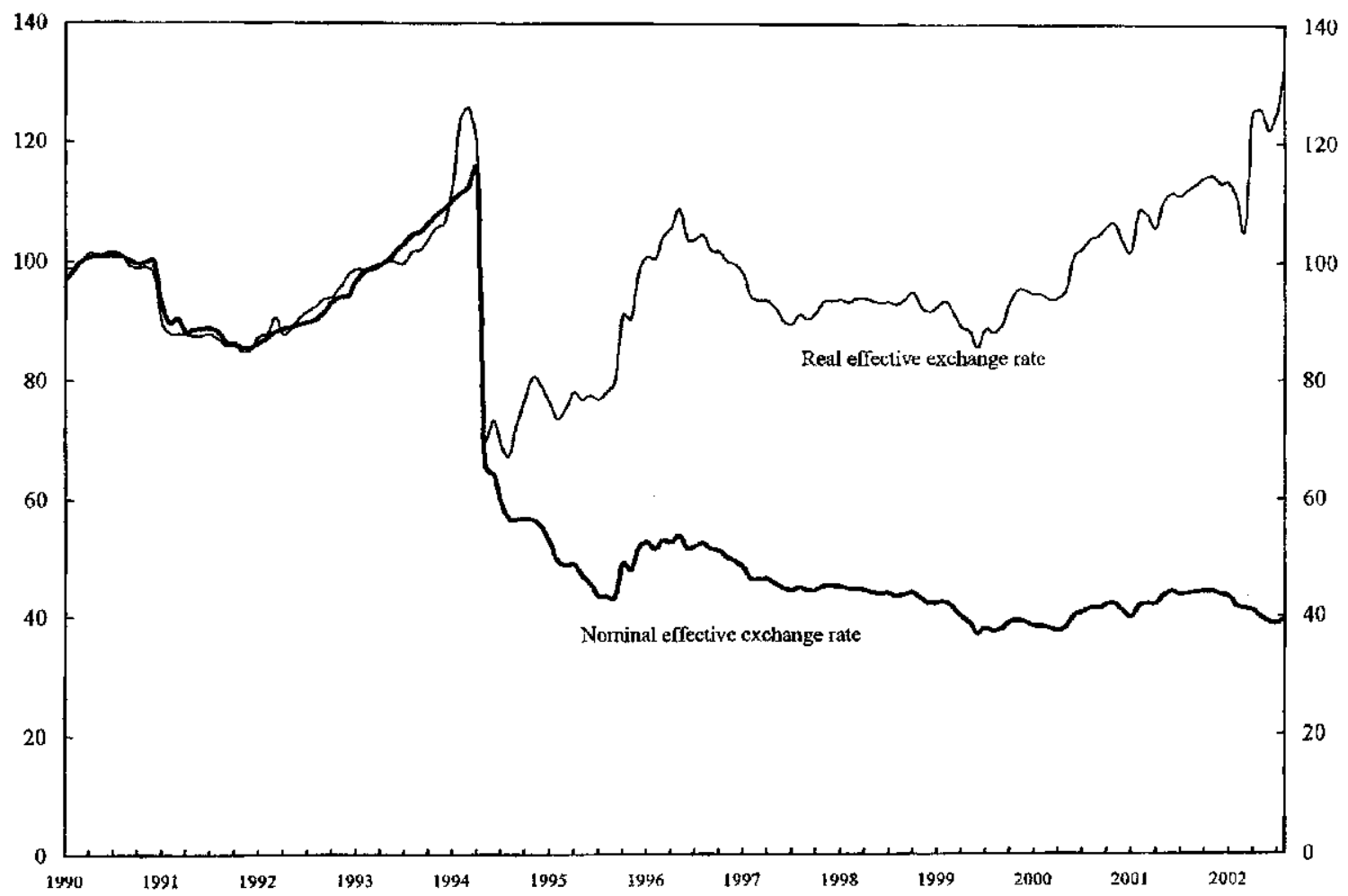

Source: IMV, Information Notice System. 
Figure 7. Madagascar: Foreign Direet lnvestment, 1970-2000

(In percent of GDP)

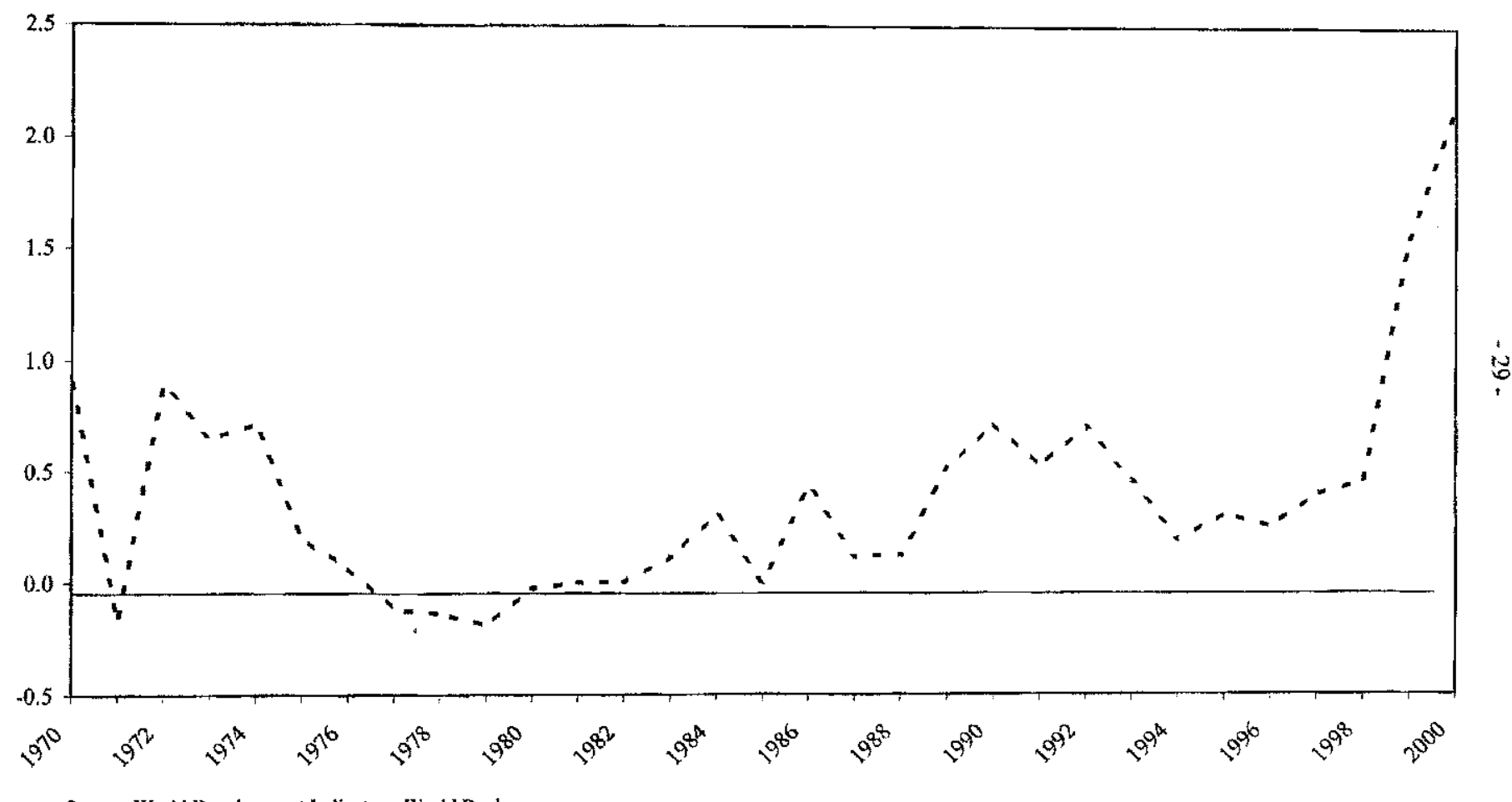

Source: Worid Development lndicators, World Bank.

CInternational Monetary Fund. Not for Redistribution 
Figure 8. Madagascar and Sclected Comparator Countries:

Monthly Wage in Manufacturing, 1963-2000

(In U.S. dollars)

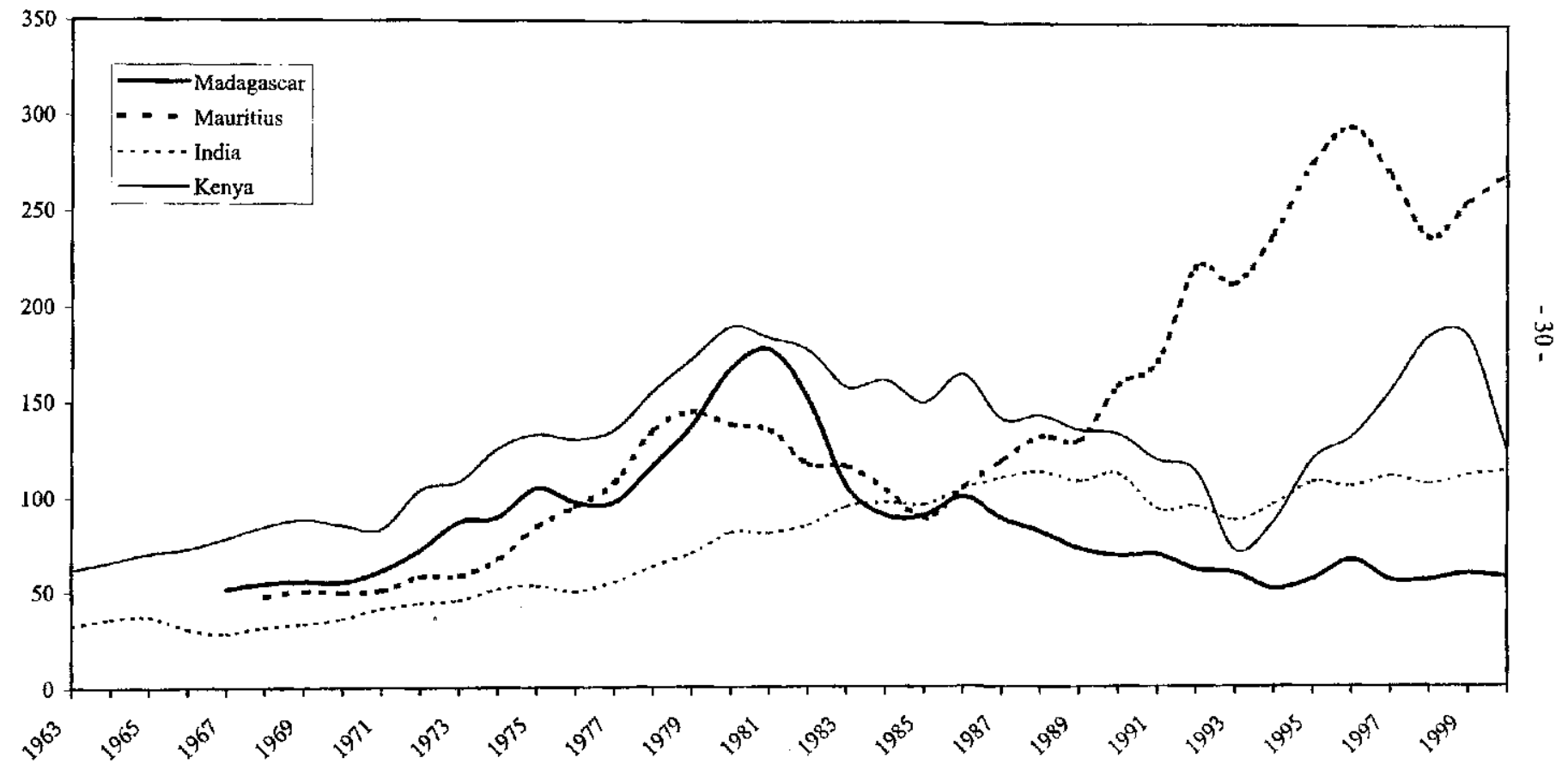

Sources: UNDDO; MF staff, and the author's calculations. 
Figure 9. Madagascar: Constant-Market-Share Export Growth Decomposition, 1992-2001

(Base Year $=1991$ )

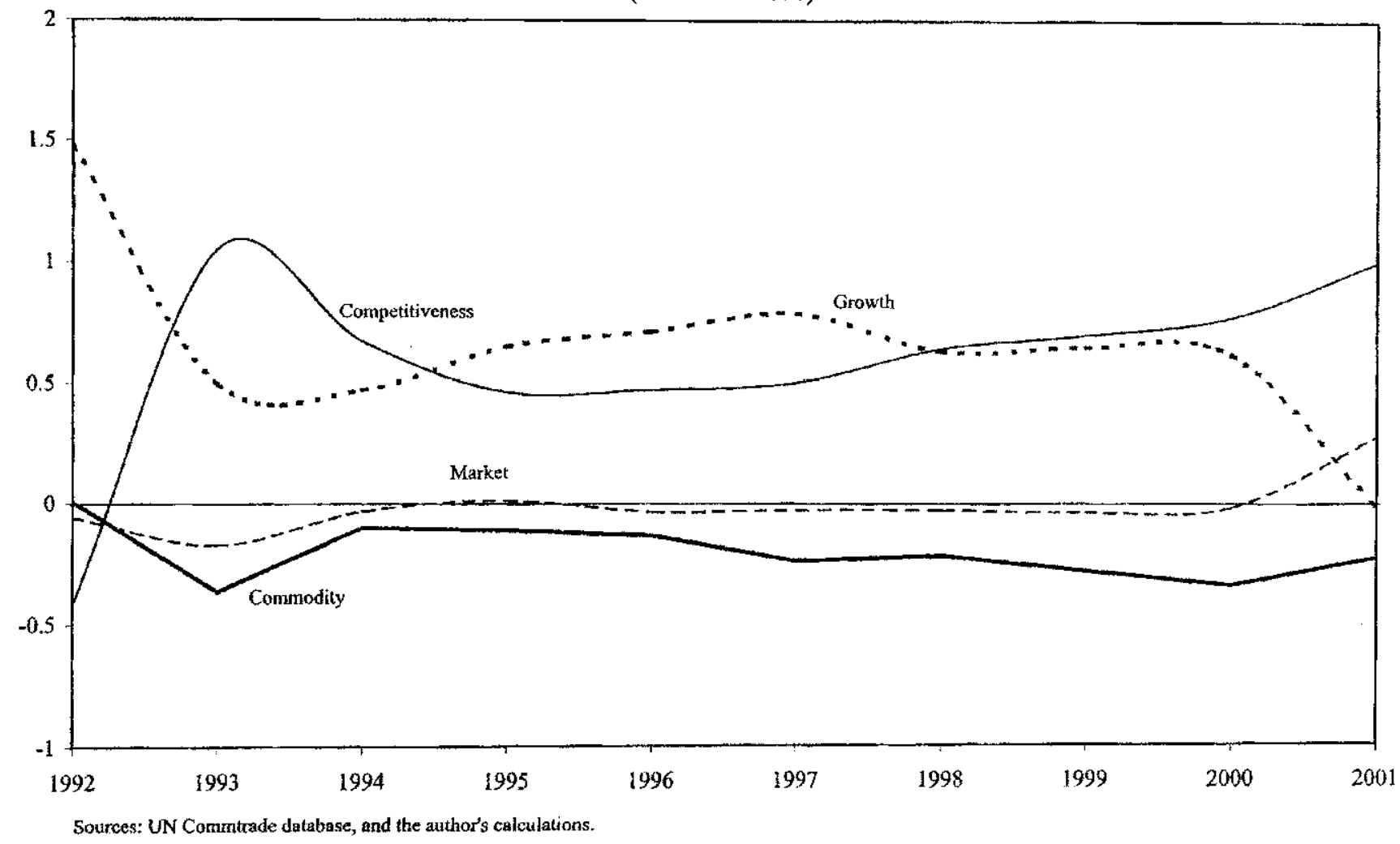


Madagascar: Summary of the Malagasy Tax System, June 2002

(All amounts in Malagasy francs)

Tax
1. Taxes on net theome
and proifits
1.1 Taxes on comporations
1.1.1 Tax on company

1.3.1 Tax on eompeny

profit [impô sur les

bénéfices des Sociésés-IPS]

Corporate prolit tax (IBS)

(General Budgel)
Anticle 01.01.02

Annugl tax on the full range of

profits carted by companies

headquartered in Madagascar, as well as income generated by the possession of property (assets) or the practice of a gainhin! activity in Madagascar.
Article 01.02.03

Anticie 01.01 .16

income eamed by partnerships,

religious missions and churches, of $18 \mathrm{BS}$ at 35 percent.

cultural associations is exempt from

tax. However, the tax is payable in Taxable minimum

respect of their establishments

engaged in sales or provision of services.

- Interest paid by the caisse

d'Épargne de Madagascar.

- Capital gains on saics of real estate.

- Income and capital gains deriving from the sales of stocks and shares beld by SCRs.

50 percent of invesiment expenditures expensed, up to 50 percent of JBS

before investment deduction; utlimited camyforward of unused deductions

Ineome eaned by norprofit

organizations or associstions

exclusively engrged in the promotion

of small- and medium-scale

enterprises.

Compaties registered under the export processing zone (EPZ) regine (hereafter, EPZ, companies): IBS tax

boliday of 2 to 15 yeats
Tax Rate

Tax Reporting
$200,000+5$ per mill of turnove: agriculture, crafts, indistry, mining, hotel trade, tourism, or transportation

$800,000+5$ per mill of urnover for the rest.

Article 01.01.06 6ìne

Deficit may be carried forward for a period of the years.

Deflcit may be carried forward for a period of thee years.

EPZ, companies: 14 percent.
Axticic 01.01.17

- P'rior to May I (catendar year)

- Prior to Oetober I (June 30); and

- Within the two mornhs following the coud of the fiscal period (plus 50 percent).

On collection:

Articke 20.01.41

Estirnated payments

(A) Payable ofz a somiannual basis

Article 20.01.42.

(B) Payatle at customs ("acompte

IBS'):

- 3 percent c.i.f value if registered; and

- S percent of c.if. vatue in uther cases on value of taw materials and consumer gooks. 
Madagascar: Summary of the Malagasy T'ax System, June 2002 (All amounts in Malagasy francs)

\begin{tabular}{|c|c|c|c|c|}
\hline $\operatorname{Tax}$ & Туре of Tax & Deducliuns and Exernptions & Tax Ratc & Tax Reporting \\
\hline $\begin{array}{l}\text { 1.1.2 Global tax [Impót } \\
\text { synthétiquel (General } \\
\text { Budget) }\end{array}$ & $\begin{array}{l}\text { Article } 01.06 .02 \\
\text { FMG } 600,000 / \text { year<tumover } \\
\text { exclusive of tax < FMG } \\
12,000,000 \text { year: } \\
\text { - Representative (and affrording } \\
\text { full discharge in respect of } \\
\text { the TP, the IRNS, and TCA; } \\
\text { - Tax earmarked for the } \\
\text { tinancing of the regionalized } \\
\text { investunent program; and } \\
\text { - Individuals engaging in an } \\
\text { independent activity, whether } \\
\text { or not liable for the TP tax. }\end{array}$ & $\begin{array}{l}\text { Article.01.06.03 } \\
\text { - Corporations; and } \\
\text { - Wholesale and semi-wholesale } \\
\text { merchants [commerçants de gros et } \\
\text { denni-gros]. }\end{array}$ & $\begin{array}{l}\text { Article 01.06.06 } \\
6 \text { percent, although niay not be less than IMG } 25,000 \text {. }\end{array}$ & $\begin{array}{l}\text { Article } 01.06 .07 \\
\text { Ifax return filed prior to March } \\
31=>\text { liable for the TP tax. } \\
\text { Article Q1.06.08 } \\
\text { In the three wonths following the } \\
\text { issuance of the certificate of } \\
\text { payment of tax [titre de } \\
\text { liquidation] } \Rightarrow \text { other. }\end{array}$ \\
\hline $\begin{array}{l}\text { 1.2 Taxes on individuals } \\
\text { 1.2.1 Tax on capital incorte } \\
\text { [Impots sur les revenus de } \\
\text { capitanx mobiliers-IRCM] } \\
\text { (General Budget) }\end{array}$ & $\begin{array}{l}\text { Article } 01.04 .01 \\
\text { Occasional thx collected upon the } \\
\text { distribution of profits. }\end{array}$ & $\begin{array}{l}\text { Article 01.04.25 et sed. } \\
\text { - Anrortization and repoyment of } \\
\text { principal realized upon liquidation } \\
\text { of real estatc assets; and } \\
\text { - Loans or obligations of } \\
\text { cooperatives, centril mutual credit } \\
\text { fund organizations. } \\
\text { Article } 01.04 .32 \\
\text { lnterest on national loans [emprunts]: } \\
\text { - Contracted for purposes of } \\
\text { investment with external financial } \\
\text { institutions. }\end{array}$ & $\begin{array}{l}\text { Article } 01.04 .07 \\
\text { - } 25 \text { percent } \\
\text { - } 30 \text { percent for individuals - the IRCM is in discharge of } \\
\text { the IRNS. } \\
\text { - } 15 \text { percent on interest paid on cash or cash security } \\
\text { deposits of individuals or non-profit entities. } \\
\text { - } 10 \text { percent - dividends of EPZ conipanies. }\end{array}$ & $\begin{array}{l}\text { Article } 01,04.15 \text { (Art, } 01,04.10 \\
\text { abrogated) } \\
\text { Distribution of dividends: Before } \\
\text { April } 30, \text { (fiscal period ending the } \\
\text { second scmianuual period) or withis } \\
\text { the first } 20 \text { days of October. }\end{array}$ \\
\hline $\begin{array}{l}\text { 1.2.2 Capitalization tax } \\
\text { [Taxe d'incorporation] } \\
\text { (General Budget) }\end{array}$ & $\begin{array}{l}\text { Article (44,01.33 } \\
\text { Occasional tax collected upon the } \\
\text { capitalizalion of profits or } \\
\text { reserves. }\end{array}$ & $\begin{array}{l}\text { Article 01.04,34 } \\
\text { Not collected to the extent that the } \\
\text { capitalization of reserves or profits has } \\
\text { as its counterpart the prior acquisition } \\
\text { of capital goods or acquisition of } \\
\text { equity holdings in the new capital of } \\
\text { other firms, or expcnditures on the } \\
\text { occupational training of local } \\
\text { personnel, or creation of additional } \\
\text { jobs. }\end{array}$ & $\frac{\text { Avticle } 01.04 .33}{8 \text { percent. }}$ & \\
\hline
\end{tabular}

\section{CInternational Monetary Fund. Not for Redistribution}


Madagascar: Summary of the Malagasy Tax System, June 2002

(All amounts in Malagasy francs)

\begin{tabular}{|c|c|c|c|c|}
\hline $\operatorname{Tax}$ & Type of Tax & Deductions and Lxemptions & Tax Rate & Tax Reporting \\
\hline $\begin{array}{l}1.2 .3 \text { Tax on transfers } \\
\text { abroad [Taxe forfaitoire sur } \\
\text { les Iransferts] (Generat } \\
\text { Budget) }\end{array}$ & 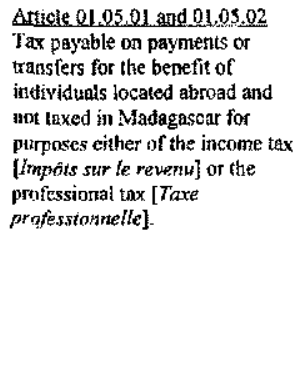 & $\begin{array}{l}\text { Aricle } 01.05 .03 \\
\text { - Amounts received in connection } \\
\text { witl scholarships; } \\
\text { - Sale price of igmovable or } \\
\text { movabic assets; } \\
\text { - Products aiready liable for the } \\
\text { IRCM; } \\
\text { - Repayment of principal on loans; } \\
\text { - Standard price tor purchases of } \\
\text { imported merchandise; } \\
\text { - Interest paid by the Pubtic Treasury } \\
\text { or the Central Bank; and } \\
\text { - Interest on national loans } \\
\text { [emprunts] (01.04.32) }\end{array}$ & $\frac{\text { Article 0l.05.05 }}{15 \text { percent. }}$ & Withlsekd at source. \\
\hline $\begin{array}{l}\text { 1.2.4 Real estate capital } \\
\text { gains tax [impoit sur la phus- } \\
\text { value immobiliere-DVYl] } \\
\text { (Genesal Budget) }\end{array}$ & $\begin{array}{l}\text { Avticle } 02.12 .02 \\
\text { Taxed assessed on transfers (for } \\
\text { valuable consideration) of real } \\
\text { estate asscts or claims. }\end{array}$ & $\begin{array}{l}\text { Article } 02.12 .03 \\
\text { Capital gains on sales of real estate } \\
\text { included in cument inventuries [siock } \\
\text { en coutrs] by Soctete immobilière. }\end{array}$ & 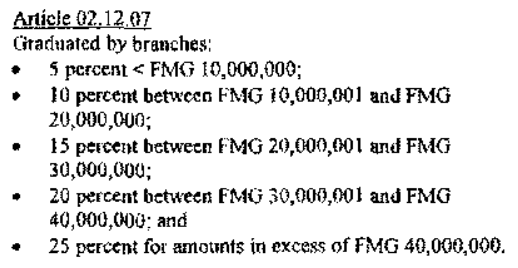 & \\
\hline $\begin{array}{l}1.2 .5 \text { yersonsl wage } \\
\text { income tax - IRSA (General } \\
\text { Budgel) }\end{array}$ & 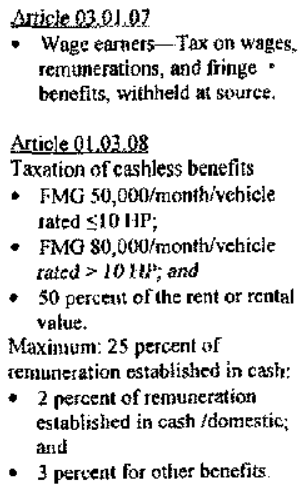 & 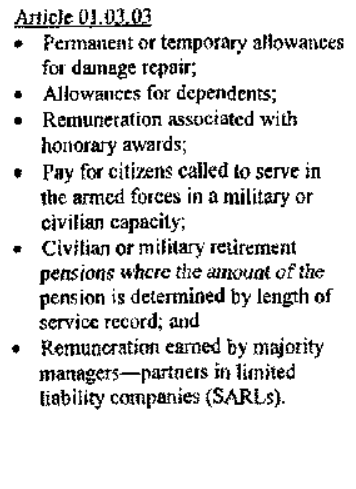 & 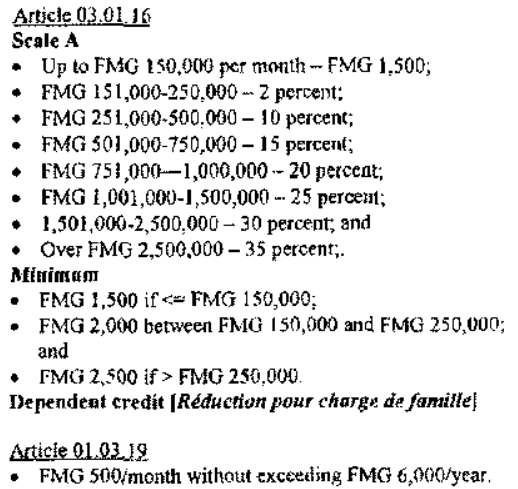 & $\begin{array}{l}\text { Aricle 01 } 03.12 \\
\text { Witheld and paid prior to the } 15^{\text {th }} \\
\text { of the following month. } \\
\text { Jf annount withheld is less than } \\
\text { FMO } 25,000 \text { or if wages are paid } \\
\text { on a quarterly basis wage bilt, tax } \\
\text { payments may be cumulated on a } \\
\text { quarterly basis. and withlueid and } \\
\text { paid within the first } 15 \text { days } \\
\text { followirg the chd of the quanter. }\end{array}$ \\
\hline
\end{tabular}

\section{CInternational Monetary Fund. Not for Redistribution}


Madagascar; Summary of the Malagasy Tax System, June 2002

(All anounts in Malagasy francs)

1.2.6 Nonwage persona? inconte tax - IRNS (Geperal Budget)

1.2.7 Nonwage personal income Lax [IRNS Greffie] (01.02.50) (General Budget)
Artiche 01.02 .02

- Sole proprietorship;

- Income eaned from engaging in an independent profession;

Corporate income, not liable for JBS tax;

- Remuneration of SARL majority mantgers/partners:

- Profits of firns engaged in industrial or commersial, crafts-retated, tourism-related or service-providing activities or farms:

- Income from land; and

- Income carised in connection with the functions and responsibilities of persons not having the status of merchants [non-commercants].

\section{Article 01.02 .20}

Small- and nedium-scale

enterprises (ctiteria):

- Number of employees $\ll=50$;

- Pretax turnover below FMG $250,000,000$; and

- Yrincipal responsibilities in prodection, sale where the management is usndertaken by individuais venturing their own capital.

Article 01 02,24

Microentenprise (criterin):

- Turnover < FMG 100,000,000 per ycar for agricuttural. crafts-related, or purchase/resale activity; and

- Turnover < FMG 50,000,000 per year for the provision of services.
Aricle 01.02.03

Net income from developed real estale oceupied by the owner as a principal residence;

- Capital gains earned on selling the prupesty.

- Interest on bearer cash vouchers [bons de caisse anonymes];

- interest on the recurted balances of savings accounts, when such accounts are blocked for six consecutive months; and

- interest paid by the Treasury on a national loan [emprumt natiomai].

Article 01.02.12

Taxabie base.

Nondeductibility of deficits incurred in connection with conmercial, hotel related, tourism rejated, mining or

transport delicits, of in respect of land incone or investment income.

Deficit may be carried forward for a period of three years.

The amount of the aeficit to be carried forward is deducted prior to the deduction for deferred anortization.

\section{Article 01.0236}

\section{Tax scaie}

Accoutsts-based (itcmized) system [régime réel] and smalland medium-scale enterprises

- Up w FMO 250,000 per year (fixed) FMG 10000

- FMG 25L,000-5OM 600,000 $\sim 5$ percent:

- FMG 601,000-1,000,000-10 percent:

- FMG 1,001,000-1,500,000-15 percent

- FMG 1,501,000-2,500,000-20 percent

- FMG 2,501,000-5,0000,000 - 25 percent.

- FMG 5,001,000-10,000,000 - 30 percent; and

Amounts exceeding FMG $10,000,000-35$ percent.

Articie 01.02 .37

Minimum amounts for all activities liable for tax $T P>5^{5}$ class $=5 \mathrm{TP}$

Anticle 01.02.38. Party subject to IRNS registration tax (minimum)

For agriculnural activities:

- [/2 JFr fland tax] for arable land having a strface area of less than 5 hectares;

- IFT for land between 5-10 hectares

- 2 [FT for land exceeding 10 hectares;

- 3 TP: activities classed under the $6^{\text {th }}, 7^{\text {th }}$, and $8^{\text {th }}$ classes of the TP;

- 4TP: activitics classed in the $5^{\text {th }}$ class of the TP.

- 5 TP: liabie for the $4^{\text {th }}$ class of the TP; activitits categorized under the $4^{\text {th }}$ elass of the TP; and

- 5 TP: livestock merchants.

Yes, and only if the turnover < the thresholds indicated in the pertinent column.
Article 01.02.17

Accounts-based (itemized) system

(prior to May 1).

Prior to October 1 ,

Two montls from end of fisca

period plus 25 percent.

Article 20.01.41

An advance puyment [acompre

provisionne $\eta$ is due every

bimonthyy perion.

Article 20.01. 42

An advance payment [acompte] is to

be made at custorns:

- 3 percent of c.l.f. value for registered businesses; and

- 5 percent of c.i.f. value for nonregistered businesses.

Vakue: taw materials, consumer

goods, and products.

Anticie 01,02.21

System apslicable to small- and niediun-scale enterprises

(Tax retum to be fled prior to

March 1, in the year in which the option is exercised).

\section{Articte 01.02 .25}

Registered system [regime greffé]

(Tax return prior to March 1 ). 
Madagascar: Summary of the Malagasy Tax System, June 2002

(All amounts in Malagasy francs)

\begin{tabular}{|c|c|c|c|c|}
\hline $\operatorname{Tax}$ & Type of Tax & Deductions and Exemptions & Tax Rate & Inx Reporting \\
\hline $\begin{array}{l}\text { 1.2.8 Professional taxes. } \\
\text { Professional tax }{ }^{1 /}[\text { Taxe } \\
\text { professionnelle-TP] } \\
\text { (Budget of the Autonomous } \\
\text { Provinice) }\end{array}$ & $\begin{array}{l}\text { Article } 10.01,01 \\
\text { Professional tax payable in } \\
\text { connection with engaging in } \\
\text { gainful activity in Madagascax. }\end{array}$ & 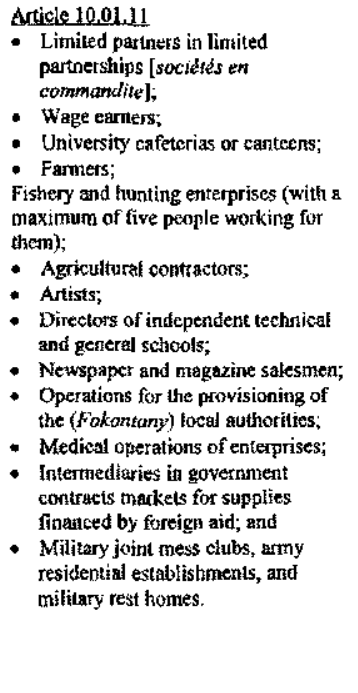 & 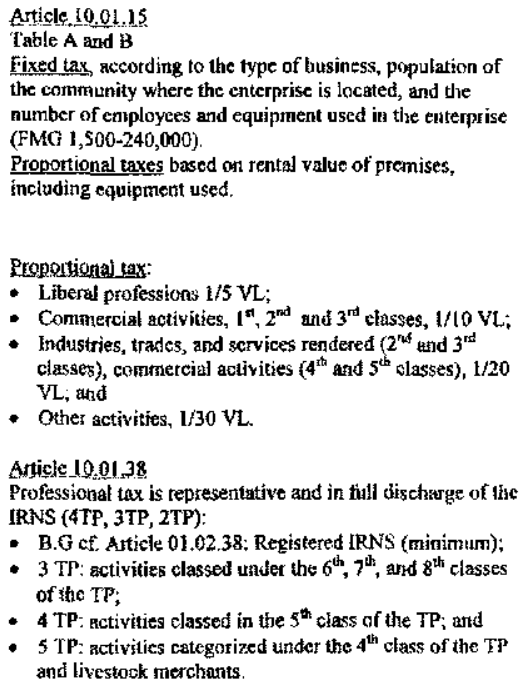 & $\begin{array}{l}\text { Article } 10.01 .33 \\
\text { Before Cotoher } 15\end{array}$ \\
\hline $\begin{array}{l}1.2 .9 \text { Business license tax } \\
\text { If }^{3} \text { [mpot de licence] } \\
\text { (Budget of the Autonomous } \\
\text { Province) }\end{array}$ & $\begin{array}{l}\text { Atticle, } 10.06,01 \\
\text { Professional tax payable on sales } \\
\text { of alcoholic beverages. }\end{array}$ & $\begin{array}{l}\text { Article } 10.06 .06 \\
\text { Sales by monptotits, including: } \\
\text { - University cafeterias; } \\
\text { - Mititary ness hals; } \\
\text { - Canteens, residential } \\
\text { establishments, clubs attached to } \\
\text { the Ammy; } \\
\text { - Pharmacists and drug depositaries } \\
\text { in connection with reteil sales of } \\
\text { raw spirit alcohol; art } \\
\text { - Restaurateurs and hotcl restaurant } \\
\text { operators, under certain conditions. }\end{array}$ & $\begin{array}{l}\text { Auticle } 10.06,08 \\
\text { Rate as folkows: } \\
\text { - Catcgory of licenses (three categuries); and } \\
\text { - Population of the community where the firm is located. } \\
\text { Article } 10.06,09 \\
\text { Liecnse for fairs: FMG } 25,000 \text { per day. }\end{array}$ & $\begin{array}{l}\text { Anticle } 10.06 .63 \\
\text { In the first } 20 \text { days of each quarter } \\
\Rightarrow \text { pre-existing operation. } \\
\text { First } 20 \text { days of operation } \Rightarrow \text { new } \\
\text { sales license. } \\
\text { Atticle } 10.06 .64 \\
\text { Ptior to operation } \\
\Rightarrow \text { huckster's license lax [impor de } \\
\text { licence forcaine]. }\end{array}$ \\
\hline
\end{tabular}


(All amounts in Malagasy francs)

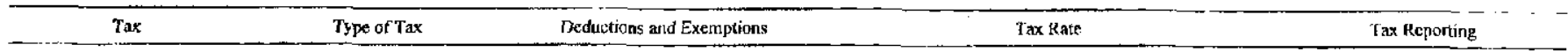

2.0 Taxes on property 2.1 Land tax I/mpout foncier sur les terrainsIFT)] (Budget of the settlement communes [communes

d'implatation $)^{1}$

\section{Articie 10.02.01}

Tax levied on the estimated productive value of land based on type of crop use.
Article 10.02.03

- Land owned by government, decentralized local euthorities, or public institutions assigned to perform a public scrvice or a service deemed to be in the public interest that generates no reverue

- Land earmarked (free of charge) for medical or social clarizics, fret education, or worship; and

- Lasid etvisaged in Article 10.03.02, liable for the IFPB.

2.2 Tax on buildings ${ }^{1 /}$ [Impots sur les inmeubles bâtts $-\mathrm{TFPB}$ ( Commune Budget)
Article 10.03.01

Tax levied on rental value of buildings.

\section{Article 10.03.03}

- Buildings owned by government, decentralizes lucal authorities, or public institutions assigned to
2.3 Local govemunent tax on buildings [Taxe annexe ['IFPB--TAFB ]" (Contmune Budget)

\subsection{Additional tax on} registration tax [Taxe additionnelie aux diroits d'enregistrement) (Commune Budget)
Auticle 10.04.01

Taxes associated with the tax on

buildings based on the renta value of $r$ eal estate.

Article 10.05.01

Tax in addition to movable and immovable property, sales by auction transfer duties [Droits d'enregistrement sur tes actes et les nutations à titre onéreux des biens tmmeuhles ef meubles]. perform a public service or a service deensed to be in the public interest that generate no revenuti: and

- New constructions for a period of five years from their conpletion date subject to presentation of habitation or occtuancy permit (Asticle 10.03.05).

- Buildings reserved (on a free-ofcharge basis) for chatitics, medical activities, [free] education, or worship.

Same ruies as those governing the iFPB, excluding the temporary exemption and the permanent exemplion.

\section{Article 10.02 .07}

Rate expressed in FMG per hectare $\left(1^{\text {st }}-5^{\text {th }}\right.$ category and 1 percent of market value ( $6^{\text {th }}$ category).

Article 10.02 .08

Privi lo (cetober 15.

\section{Article le 03,10}

Rates set hy vote (by the muricipal government) based on the rental value determined by the real estatc assessment comnitlee

Maximum rate: 5 percent; and

Minimum rate: $\mathbf{2}$ percent.

May not be iess than FMG 5000 per building.
Aricle 10.04.05.

Rate set by municipal government vole:

Maximutn rate: 5 percent; and Minimum rate: 2 percent

Asticle 10.05.02

Rates set by murticipal government yote:

Maximum rate: 5 percent; and Minimum rate: 2 percent.

\section{CInternational Monetary Fund. Not for Redistribution}


Madagascar: Summary of the Malagasy Tax System, June 2002

(All amounts in Malagasy francs)

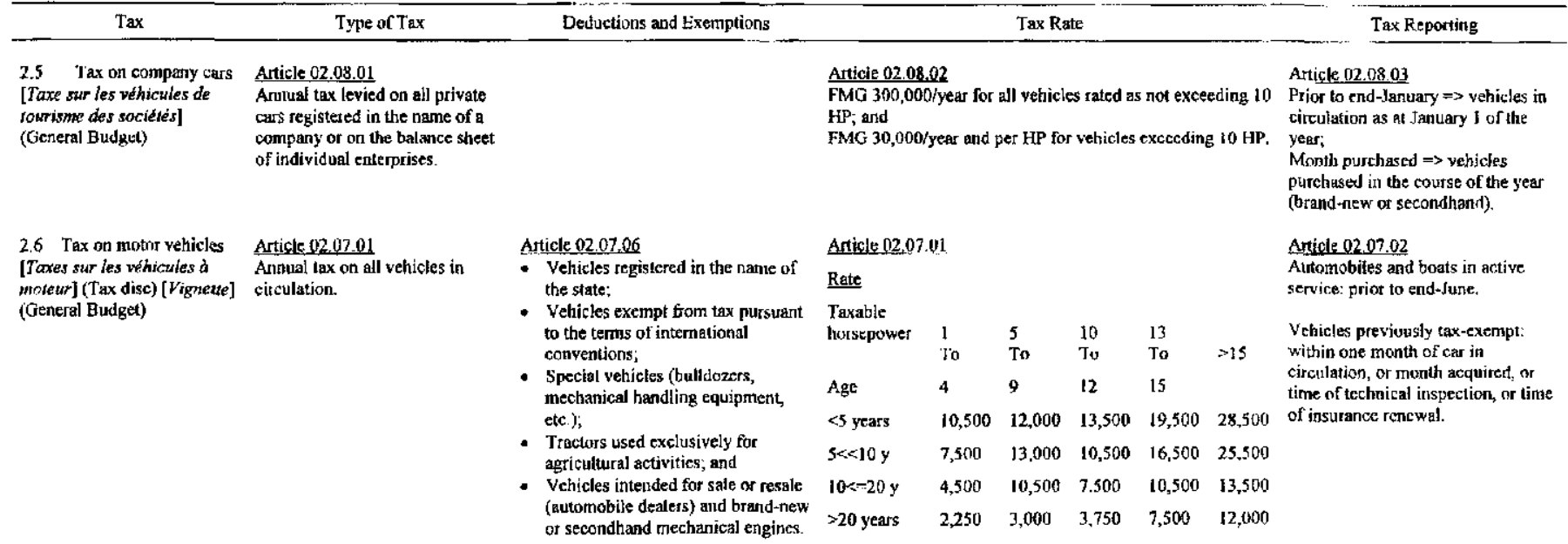

Anticle 10.05.02:

Commercial vehieles used exclusively for mass transit =

FMG 4,000/CF; however, vehicles over 10 years old are

taxed on only half their power.

Airplanes: FMG 600), $000 /$ ycar/airctan

Service vehicfes of tharities and social welfare

organizations: FMG 4,000/Cl: 
Madagascar: Summary of the Malagasy Tax System, June 2002

(All amounts in Malagasy francs)

$\operatorname{Tax}$

2.7 Registration duties [Droits d'Enregistrement] (Gentral Budget)
Article 02.01 .02

Tax levied on registration of all transactions perlaining to the transfer of ptroperty, proportioua to the value or the assets in question.

\section{Articlc 02.11.01}

Special regimes and exemptions:

- Central government and

decentralized local governments;

- Societies, assoctations recognized as being in the public interest;

- Religivus nissions and churches;

- Social housing.

- Proceciural documents [acres de procedure? and judicial decisions with respect to electoral matters;

- Instruments and acts of registration; judgments relating to civil status;

- Transactions in cases of expropriation in the public interest; and

- Instriments and transactions. contracts pertsining to agricultural or socially oriented catedit extended by banks.

\section{Anticic 02,02.39 \\ Buildings and gondwill: 8 percent.}

Special rates:

\section{Sales of immoxabje assets}

Asseciation RUP $=6$ percent (Art. 2.02.39); Developable land for torosing $<=500 \mathrm{~m} 2=8$ percent (Art. 02.02.39);

Ttaditional bousing - 10 percent; and

Agricultural land $1 / 212$ percent (Avt. 02.02.39)

Ohiner assets

8 percent (Ant. 02.02.44); and

Negotiable securities: 4 percent (Art. 02 02.46).

Estatc tax (Ast. 02.03.32-A)

Rate - Portion of taxable value

$$
\text { (in FMG): }
$$

- 2 percent-FMG 1-10 nilfion:

- 4 percent - FMO 2-20 million;

- 6percent - FMO 20-30 million

- 8 percent - FMG 30-40 million:

- 10 percent $\rightarrow$ FMG 40 million: Memoranda of incorporatisn: (Art. 02.02.32) Rate graduated by tranche of capital;

- 2 percent < FMG; 50,000,000.

- 1 percent between FMG 50,000,000 and FMG $500,000,000$; and

- 0.5 percent for amounts in excess of FMG $500,000,000$ Claims: 1.50 percent (Art. 02.02.48)

Prenuptial agtemem [contrat de martoge]: 1 percent (Avt. $02,02.19$ )

Exchange of building: 4 percent (Article 02.02.20)

Partition: I percent (Art. 132,02,28)

Anquities [Renies|: 1.5 percent (Art. 02.02.30)

Fixed-terul lesse: 2 percent and 4 percent (Art. 02.02.12)

Life tenancy: 8 percent and 12 percent (Art. 02.02,13)

\section{CInternational Monetary Fund. Not for Redistribution}


Madagascar: Summary of the Malagasy Tax System, June 2002

(All amounts in Malagasy franes)

\begin{tabular}{|c|c|c|c|c|}
\hline $\operatorname{Tax}$ & Type of Tax & Deductions and Exemptions & Tax Rate & Tax Repurling \\
\hline & $\begin{array}{l}\text { Article } 02.02 .24 \\
\text { Taxes on judgments, artitration } \\
\text { awards, and decisions resulting in } \\
\text { conviction. }\end{array}$ & & $\begin{array}{l}\text { Art. 02.02,04 through } 02,02 \text {.06 } \\
\text { Fixed taxes: } \\
\text { - FMG } 10,000 \Rightarrow \text { Supreme Court decision } \Rightarrow \\
\text { administrative; } \\
\text { - FMG } 20,000 \Rightarrow \text { Decision of the Court of Appeal, } \\
\text { Criminal Court; and } \\
\text { - FMG } 40,000 \Rightarrow \text { Decision of the Supreme Court } \Rightarrow \\
\text { judicial. }\end{array}$ & \\
\hline $\begin{array}{l}2.8 \text { Tax on real estate } \\
\text { advertising [ } \text { Toxe de } \\
\text { publictte fonciere] (General } \\
\text { Budget) }\end{array}$ & $\begin{array}{l}\text { Arlicle 02,04.01 } \\
\text { Tax levied un: } \\
\text { - Recording of real estate } \\
\text { conveyancing transactions } \\
\text { [mutations]; and } \\
\text { - Procedural steps inyolved in } \\
\text { inclusion in land ownership } \\
\text { registies. }\end{array}$ & $\begin{array}{l}\text { Article } 02.04,09 \\
\text { - Central govertument and } \\
\text { decentralized local governments; } \\
\text { - Societies, gssociations recugnixed } \\
\text { as heing in the public interest; } \\
\text { - Religious missions and clutrches; } \\
\text { and } \\
\text { - Social housing. }\end{array}$ & $\begin{array}{l}\text { Article } 02.04 .05 \\
\text { - I percent of the value (for leases): } \\
\text { - } 2 \text { percent } \Rightarrow \text { in all other cases; and } \\
\text { - } 1 \text { petcent of value in the case of uniconditional partitions } \\
\text { [partage pur et simple]. }\end{array}$ & $\begin{array}{l}\text { Article } 02.09 .05 \\
\text { Within the first } 20 \text { days of each } \\
\text { guarter } \Rightarrow \text { estimated payment, } \\
\text { June is } \rightarrow \text { general thx payment. }\end{array}$ \\
\hline $\begin{array}{l}2.9 \text { Tax on insurance } \\
\text { policies [Taxe sur tes } \\
\text { cuntrais d'assurances] } \\
\text { (General Budget) }\end{array}$ & $\begin{array}{l}\text { Article } 02.09 .01 \\
\text { Tax levied on all insuranse } \\
\text { contracts providing coverage } \\
\text { against risks or in respect of } \\
\text { annuities. }\end{array}$ & $\begin{array}{l}\text { Article } 02.09,03 \text { and Article } 02.09,04 \\
\text { - Risks covered outside of } \\
\text { Madagasear; } \\
\text { - Reinsurance; } \\
\text { - Insurance in sespect of work-relaled } \\
\text { accidents; and } \\
\text { - Insurance against risks associated } \\
\text { with shipping or civil aviation, } \\
\text { whether intrund or outbound. }\end{array}$ & $\begin{array}{l}\text { Article } 02.09 .02 \\
4.5 \text { percent in general; } \\
\text { - } 20 \text { percent for fire insurance; } \\
\text { - } 3 \text { percent for life insurance; } \\
\text { - } 4 \text { percent for insurance against risks associated with } \\
\text { shippitig, inland water transportation, or civil aviation; } \\
\text { and } \\
\text { - } 5 \text { percent for reverse mottgage annuities [rente viagere]. }\end{array}$ & \\
\hline
\end{tabular}


Madagascar: Summary of the Malagasy Tax System, June 2002

(All amounts in Malagasy francs)

\begin{tabular}{|c|c|c|c|c|}
\hline $\operatorname{Tax}$ & Type of Tax & Deductions and Exemptions & Tax Rate & Tax Reporting \\
\hline $\begin{array}{l}\text { 3. Jaxes un goods, } \\
\text { products, and services } \\
\text { 3.1 Turnover tax }{ }^{1 /} \text { [Taxe } \\
\text { sur le chiffre } \\
\text { d'alfaires-iCA] } \\
\text { (Generai Budget, Budget of } \\
\text { the Decentralized Local } \\
\text { governments-Article } \\
\text { OG.01.01) }\end{array}$ & $\begin{array}{l}\text { Article 06.01.02 and Article } \\
\text { 06.01.03 } \\
\text { Tax levied on; } \\
\text { - Conimercial, industrial, } \\
\text { agnicultural, crafts-related, } \\
\text { mining, indel-related, or } \\
\text { service-providing } \\
\text { transactions; } \\
\text { - The liberal professions; and } \\
\text { - Particular types of operations, } \\
\text { such as importalion and } \\
\text { delivery for personal use. } \\
\text { Articic 06.0l.35 } \\
\text { * The public investment program } \\
\text { (PIP) financed from extertal } \\
\text { sources. }\end{array}$ & 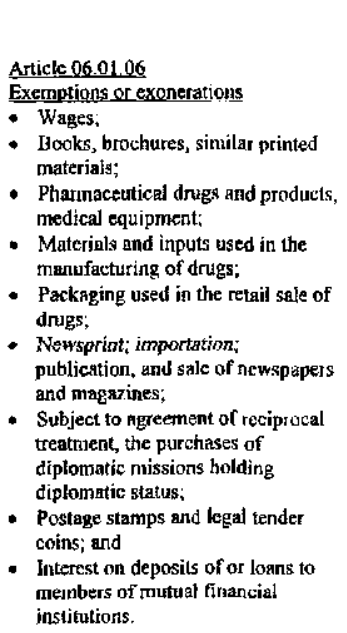 & $\begin{array}{l}\text { Article } 06.01 .12 \\
\text { Value added tax (VAT) - } 0 \text { petcent; and } \\
20 \text { percent (1ecoverable). } \\
\text { Article } 06.02 .15 \\
\text { TST: } 5 \text { percent (nonrecoverable). }\end{array}$ & $\begin{array}{l}\text { Article 06.01.16 } \\
\text { Monthly for turnover > FMO } 1 \\
\text { billion. } \\
\text { Quarterly for turnover < FMG } 1 \\
\text { bitlion. } \\
\text { Article } 06.02 .11 \\
\text { TST: Binonthly. } \\
\text { Prior to the } 20^{\text {fi }} \text { of the month } \\
\text { following eact birnonthly petiod. }\end{array}$ \\
\hline $\begin{array}{l}3.2 \text { Transaction } \operatorname{tax}[\text { [Taxe } \\
\text { sur les transactions--TST] }\end{array}$ & $\begin{array}{l}\text { Article } 06.02 .01 \\
\text { Budget of the decentralized local } \\
\text { govemments. }\end{array}$ & $\begin{array}{l}\text { Article } 06.02 .04 \text { and Article } 06.02,05 \\
\text { - Assets brouglt into companies; } \\
\text { - Services rendercd in the context of } \\
\text { the health-care professions; } \\
\text { - School fees; } \\
\text { - Supply of water and electric power } \\
\text { to public local authorities for } \\
\text { domestic use, to medical training } \\
\text { centers; and } \\
\text { - Export sales. }\end{array}$ & $\frac{\text { Article } 06,02.15}{5 \text { percent. }}$ & $\begin{array}{l}\text { Article } 06.02 .1 \mathrm{I} \\
\text { In the first } 20 \text { days of the month } \\
\text { following each bimonthly period. }\end{array}$ \\
\hline
\end{tabular}


Madagascar: Sunmary of the Malagasy Tax System, June 2002

(All amounts in Malagasy francs)

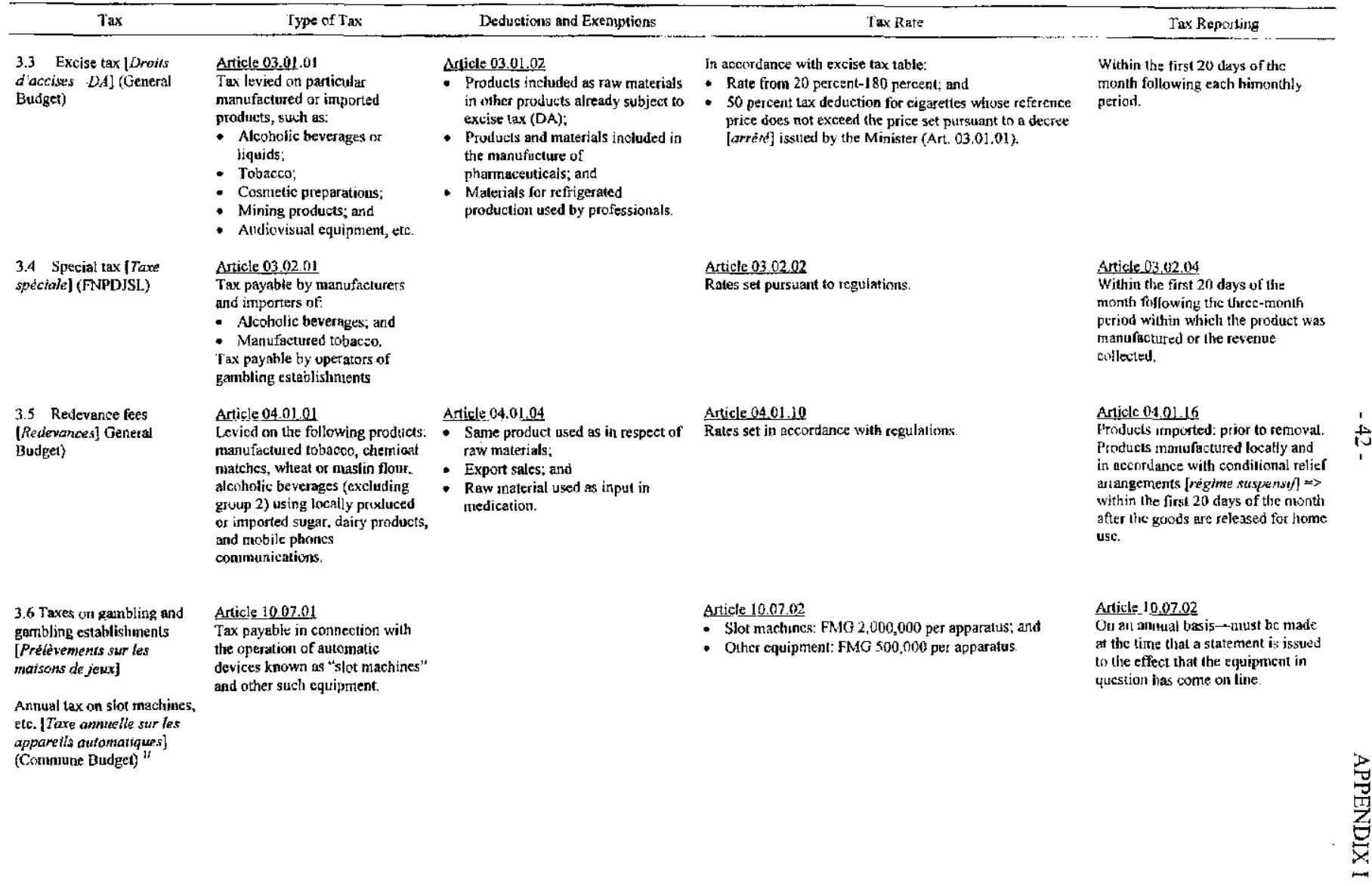

\section{CInternational Monetary Fund. Not for Redistribution}


Madagascar: Summary of the Malagasy Tax System, June 2002

(All amounts in Malagasy francs)

\begin{tabular}{|c|c|c|c|c|}
\hline $\operatorname{Tax}$ & Type of Tax & Deductions and Exemptions & Tex Rate & Tax Reporting \\
\hline $\begin{array}{l}\text { Stamp tax [Droit de timbre] } \\
\text { (General Budgct) }\end{array}$ & $\begin{array}{l}\frac{\text { Article } 03,02,12}{\text { Tax payable upon admittance to }} \\
\text { gambling holls. }\end{array}$ & & $\begin{array}{l}\text { Article } 03,02,12 \\
\text { By share: } \\
\text { - FMG } 50,000, \text { pass valid for one diny; } \\
\text { - FMG } 200,000 \text { - pass valid for one week; } \\
\text { - FMG } 700,000 \text { - pass valid for one ruonth; and } \\
\text { - FMG } 3,000,000 \text { - pass valid for one year. }\end{array}$ & $\begin{array}{l}\text { Azticle } 03,02.12 \\
\text { Prior to the } 10^{\text {th }} \text { of the following } \\
\text { month. }\end{array}$ \\
\hline $\begin{array}{l}\text { Tax on gambling products } \\
\text { [Prélivement sur les prodwits } \\
\text { des jever] (Decentealized local } \\
\text { government budget to be } \\
\text { allocated by decree) }\end{array}$ & $\begin{array}{l}\text { Article } 10.07 .03 \\
\text { Tax (in full discherge of the value } \\
\text { added tax (VAT) applied to the } \\
\text { gross proceeds from money- } \\
\text { gambling activities engaged in } \\
\text { within cluts, gambling houscs, } \\
\text { and botel facilities. }\end{array}$ & & $\begin{array}{l}\text { Article } 10.07 .03 \\
\text { Gambling engaged in at cluhs and ganbbling houses: } \\
\text { Graduated by threshold of annual earnings (mitsimum rate } \\
\text { of } 10 \text { percent, maximum rate of } 60 \text { percent). } \\
\text { Gambling in hoteis: graduated by threshold of earsings } \\
\text { (min. } 5 \text { percent, max. } 40 \text { percent). }\end{array}$ & $\begin{array}{l}\text { Article } 10.07 .06 \\
\text { Within the tluee days after the end } \\
\text { of the ten-day period. }\end{array}$ \\
\hline $\begin{array}{l}3.7 \text { Annual tax on } \\
\text { televisions [Taxe annuelie } \\
\text { stur les teléviseurs] (Budget } \\
\text { of the Communtes) }\end{array}$ & $\begin{array}{l}\text { Article } 18 \\
\text { Amending Paragraph I of Article } \\
6 \text { of Order [Ordonnance] No. } \\
78009 \text { of May 3, 1978. }\end{array}$ & & FMG 20,000 per TV per year. & \\
\hline
\end{tabular}

4. Taxes on foreign lrade

4.1. Inports

4.1.1 Customs duty (Droit

de donane d ('entrde)

Levied mostly on c.i.f. value of inperts

\subsubsection{Import tax (Taxe d'importation)}

4.1.3 Statistical tax (Taxe Statistique à l'mportation. ISI)

4. I.4 Stamp duty on imports (Droil de Timbre a

I'Jmportation)

4.1.3 VAT

Levied mostiy on c.i.f. value of imports.

Levied mostly on c.i.f. value of imports.

\section{Levied mostly on c.i.f. value of} imports.

Levied mostly on c.i.f. value plus
Exemptions apply to several products listed in the Code and in the Customs Tariff.

Impors of EPZ companies henefit form temporary ademission regime.

Exemptions apply to few products listed in the Code and in the Customs Tarilr. customs duty and import duty.
Exemptions apply to few products listed in the Code and in the Customs Tariff.

Exemptions apply to few products listed in the Code and in the Customs Tariff.

Exemptions apply to several products listed in the Code and in the Customs Tariff.

\section{$0,5,15$, and 20 percent (sec note under import tax).}

$0,5,15,20$ or 25 percent (most belween 0 and 10 percent) Note' the sum of the custom duty and import duty musl be equal os 5, 15, 25, or 30 percent, not exceeding the latier.

2 percent.

1 percent.

20 percent single-stage tax.

\section{CInternational Monetary Fund. Not for Redistribution}


Madagascar: Summary of the Malagasy Tax System, June 2002

(All amounts in Malagasy francs)

Tax

Deductions and Exemptions

Tax Rate

Tax Rejorting
Levied on a few products, mostly Exemptions apply to most products laxury items.

Al imports from EYZ companies.

Levied mostly on volume, except Excmption for lamp oils.

lubricants on ci.f. value, and

gases per Kinct.

petroleum products ( $T$ a

unique sur produst

pétroiters- TUP'

4.2 Exports
All taxes on exports eliminated as

of 1997 .
Rates varying from 10 to 120 percent. FMG 20,0 (60/Knet for secondhand clothing.

Specifie taxes vary per product.

\section{Other taxes}

Stamp tax [Droit de timbre] (General Budget)
Article 02.06 .01

Tax levied on all paper

documents intended for civil and

judicial proceedings, as well as

for instrunients that can be

produced in court and entered

into evidence.
Article 02,06.16 Size stamp tax (from FMOH1,000 to 2,000). Article 02.06.44

Article 02,06.28 Proportional tax: 5 per mill

Asticle 02.06.40 Receipt tax:

at the rate for the proportiontal tax.

suticle 02.06.66 Stamp tax on visas lix foreigners (from

FMG 140,000 in 300,000 for new issue according to length

of stay, for renewal, or for exit); reduced in half for

missionaries of all creed and foreign students in a

Madagascar university or equivalen

Source: Ministry of Budget and Developenett of Antonomous Proviaces.

I/ Levied on behalf of hocal authorities.

\section{CInternational Monetary Fund. Not for Redistribution}


Table ]. Madagescar: Growtit: and Structure of GDP, 1997-2001

\begin{tabular}{|c|c|c|c|c|c|}
\hline & 1997 & 1998 & 1999 & 2000 & 2001 \\
\hline & \multicolumn{4}{|c|}{ (Armual change in pereent, at 1984 prices) } & \\
\hline Primary sector & 1.9 & 2.1 & 3,4 & 0.8 & 4.0 \\
\hline Agricultare & 1.6 & -1.6 & 5.3 & -2.4 & 5.5 \\
\hline Livestock and fisharies & 0.6 & 4.5 & -2.7 & 2.6 & 3.1 \\
\hline Foresiny & 7.6 & 8.3 & 17.5 & 5.7 & 2.3 \\
\hline Secondary sector & 4.7 & 5.3 & 4.2 & 3.6 & 7.6 \\
\hline Food, beverages, and tobacco & 2.4 & 8.9 & 4.2 & 4.3 & 4.9 \\
\hline Energy & 17.2 & $-i, 6$ & 4.1 & 5.0 & -6.3 \\
\hline Expont processing zone & 9.7 & 20.0 & 22.4 & 22.4 & 40.0 \\
\hline Other & 0.7 & 1.2 & 0.4 & 3.4 & 10.3 \\
\hline Tertiary sector & 4.7 & 5.1 & 5.5 & 6.7 & 6.1 \\
\hline Tratsport & 8.5 & 4.5 & 4.4 & 5.7 & 5.7 \\
\hline Construction & 4.7 & 1.3 .3 & $1 t .6$ & 15.1 & 23.5 \\
\hline Retail and wholesale & 2.8 & 2.9 & 3.3 & 3.3 & 4.3 \\
\hline Goveimment & 0.0 & 0.1 & 0.0 & 0.0 & 2.0 \\
\hline Other services & 3.6 & B.6́ & 10.0 & 11.7 & 8.3 \\
\hline GDP at market prices & 3.7 & 3.9 & 4.7 & 4.8 & 6.0 \\
\hline Real GDP per capita & 0.7 & 0.9 & 1.6 & 1.8 & 3.0 \\
\hline \multirow[t]{2}{*}{ GDP deflator } & 7.3 & 8.4 & 9.8 & 7.1 & 9.6 \\
\hline & \multicolumn{4}{|c|}{ (In percent of GDP at current prices) } & \\
\hline Primary sector & 29.2 & 28.1 & 27.2 & 26.1 & 27.3 \\
\hline Agriculture & 162 & 15.4 & 14.9 & 14.3 & 14.9 \\
\hline Livestock and fisberies & 8.0 & 7.9 & 7.5 & 7.2 & 7.5 \\
\hline Forestry & 5.0 & 4.8 & 4.8 & 4.6 & 4.8 \\
\hline Seconsary sector & 12.4 & 12.5 & 12.5 & 13.0 & 13.3 \\
\hline Food, beverayes, and tobacco & 5,6 & 5.9 & 5.7 & 6.0 & 6.1 \\
\hline Energy & 1.4 & 1.3 & 1.4 & 1.4 & 1.4 \\
\hline Export processing zane & 1.8 & 1.8 & 2.0 & 2.1 & 2.1 \\
\hline Otber & 3.7 & 3.6 & 3.4 & 3.5 & 3.6 \\
\hline Tertiary sector & 52.0 & 52.5 & 52.3 & 52.0 & 52.3 \\
\hline Tratsopost & 17.9 & 18.0 & 17.3 & 17.2 & 12.3 \\
\hline Constraction & 1.3 & 1.5 & 1.5 & 1.5 & 1.5 \\
\hline Retuin and wholesale & 12.4 & 11.7 & 11.2 & 31.2 & 11.2 \\
\hline Goversment & 4.9 & .5 .2 & 5.4 & 5.4 & 5.4 \\
\hline Other services & 15.5 & 16.2 & 16.9 & 16.8 & 16.9 \\
\hline Of which: public sector' & 4.6 & 5.2 & 5.2 & 0.0 & 0,0 \\
\hline Imputed charges & -1.2 & -1.2 & +1.3 & -1.3 & -1.3 \\
\hline GDP at factor cost & 92.5 & 91.9 & 90.7 & 89.9 & 92.5 \\
\hline Indirect taxes & 7.5 & 8.1 & 9.3 & 10.1 & 7.5 \\
\hline $\begin{array}{l}\text { Net imports of goods and } \\
\text { nonfactor services }\end{array}$ & 8.1 & 7.8 & 7.7 & 7.3 & 3.2 \\
\hline Total avaitable resources & 108.2 & 107.9 & 107.9 & 107.3 & 103.2 \\
\hline Consumption & 95.3 & 93.0 & 92.8 & 92.3 & 87.7 \\
\hline Gross imvestment & 12.8 & 14.8 & 14.9 & 15.0 & 15.5 \\
\hline Gross domestic savings & 4.7 & 7.0 & 7.2 & 7.7 & 12.3 \\
\hline
\end{tabular}

Sources: Ministry of Economy, Finance, and Budget; and Fund staff estimates.

'Exisiuding public enterprises. 
Table 2. Madagascat: Gross Domestic Product at Constant 1984 Prices, 1997-2001 (In billions of Malagasy francs at 1984 prices)

\begin{tabular}{|c|c|c|c|c|c|}
\hline & 1997 & 1998 & 1999 & 2000 & 2001 \\
\hline Primary sector & 697 & 712 & 736 & 742 & 772 \\
\hline Agriculture & 320 & 315 & 332 & 324 & 342 \\
\hline Liyestock and fisheries & 293 & 306 & 298 & 306 & 315 \\
\hline Forestry & 84 & 90 & 106 & 112 & 115 \\
\hline Secondary sector & 241 & 253 & 264 & 279 & 300 \\
\hline Food, beverages, and tobacco & 109 & 119 & 124 & 129 & 136 \\
\hline Energy & 43 & 43 & 44 & 47 & 44 \\
\hline Export processing zone & 14 & 17 & 20 & 25 & 35 \\
\hline Other & 74 & 75 & 75 & 78 & 86 \\
\hline Tertiary sector & 969 & 1,018 & 1,074 & 1,146 & 1,217 \\
\hline Transport & 336 & 351 & 367 & 388 & 410 \\
\hline Construction & 29 & 33 & 37 & 43 & 49 \\
\hline Retail and wholesale & 226 & 232 & 240 & 248 & 259 \\
\hline Government & 108 & 108 & 108 & 108 & 110 \\
\hline Other services & 269 & 292 & 322 & 359 & 389 \\
\hline Of which: public sector & 0 & 0 & 0 & 0 & 0 \\
\hline Imputed charges & -33 & -37 & -39 & -40 & -43 \\
\hline GDP at factor cost & 1,873 & 1,946 & 2,034 & 2,127 & 2,245 \\
\hline Indirect taxes & 173 & 180 & 191 & 204 & 226 \\
\hline GDP at market prices & 2,046 & 2,126 & 2,225 & 2,331 & 2,471 \\
\hline
\end{tabular}

Sources: Ministry of Econony, Finance, and Budget; and Fund staff estimates. 
Table 3. Madagascar: Supply and Use of Resources at Current Prices, 1997-2001 (in bithions of Malngasy francs)

\begin{tabular}{|c|c|c|c|c|c|}
\hline & 1997 & 1998 & 1999 & 2000 & 2001 \\
\hline Primary sector & 5.266 & 5,719 & 6,366 & 6,858 & 8,268 \\
\hline Agriculnure & 2,922 & 3,124 & 3,484 & $3,7 \varsigma 3$ & 4,525 \\
\hline Livestock and fiskeries & 1,450 & 1,615 & $1,76 i$ & 1,897 & 2,287 \\
\hline Forestry & 895 & 980 & 1,121 & 1,208 & 1,456 \\
\hline Secondary sector & 2,244 & 2,549 & $2,9] 7$ & 3,412 & 4,023 \\
\hline Food, beverages, and tobacco & 1,007 & 1,190 & 1,340 & 1,567 & 1,848 \\
\hline Energy & 246 & 262 & 316 & 370 & 436 \\
\hline Export processing zone & 330 & 369 & 466 & 54.5 & 642 \\
\hline Other & 662 & 728 & 795 & 930 & 1,097 \\
\hline Tertiary sector & 9,389 & 10,674 & 12,228 & 13,641 & 15,859 \\
\hline Tranisport & 3,238 & 3,655 & 4,035 & 4,501 & 5,233 \\
\hline Construction & 233 & 296 & 355 & 396 & 460 \\
\hline Retail and wholesale & 2,229 & 2,386 & 2,624 & 2,927 & 3,403 \\
\hline Government & 884 & 1,051 & 1,266 & 1,412 & 1,642 \\
\hline Other services & 2,805 & 3,286 & 3,948 & 4,404 & 5,121 \\
\hline Imputed charges & -208 & -238 & -309 & -329 & -389 \\
\hline GDP at factor cost & 16,692 & 18,705 & 21,202 & 23,583 & 27,761 \\
\hline Indirect taxes & 1,359 & 1,638 & 2,157 & 2,659 & 2,278 \\
\hline Gross diomestic preduct at market prices & 18,051 & 20,343 & 23,379 & 26,242 & 30,334 \\
\hline Net imports of goods and nonfactor services & 1,462 & 1,578 & 1,809 & 1,919 & 959 \\
\hline Exports of goods and nonfactor services & 3,947 & 4,378 & 5,715 & 8,036 & 8,672 \\
\hline Imports of goods and nonfactor services & 5,408 & 5,956 & 7,524 & 9.955 & 9,631 \\
\hline Total available resources & 19,512 & 21,921 & 25,188 & 28,161 & 31,292 \\
\hline Consumption & 17,199 & 18,914 & 21,704 & 24,197 & 26.589 \\
\hline Government & 1,960 & 2,089 & 2,175 & 2,403 & 3,082 \\
\hline Nongovernment & 15,239 & 16,825 & 19,529 & 21,795 & 23,508 \\
\hline Investment & 2,313 & 3,007 & 3,485 & 3,948 & 4,703 \\
\hline Government & 3,177 & 1,612 & 1,616 & 1,766 & 2,181 \\
\hline Nongovernment & 1,136 & 1,395 & 1,869 & 2,182 & 2,522 \\
\hline Gross domestic savings & 852 & 1,429 & 1,675 & 2,029 & 3,744 \\
\hline Government & -213 & 76 & 492 & 665 & -53 \\
\hline Nongovernment & 1,066 & 1,353 & 1,383 & 1,364 & 3,797 \\
\hline
\end{tabular}

Sources: Ministry of Economy, Einance, and Bndget; and Fund staff estimates. 
Table 4. Madagascar: Production of Rice and Other Food Crops, 1997-2001 (In thousands of tons)

\begin{tabular}{|c|c|c|c|c|c|}
\hline & 1997 & 1998 & 1999 & 2000 & 2001 \\
\hline Faddy & 2,558 & 2,447 & 2,570 & 2,480 & 2,662 \\
\hline Maize & 178 & 155 & 175 & 170 & 180 \\
\hline Manioc & 2,418 & 2,412 & 2,461 & 2,463 & 2,510 \\
\hline Sweet potatoes & 510 & 511 & 522 & 513 & 525 \\
\hline Potatoes & 280 & 281 & 291 & 287 & 295 \\
\hline
\end{tabular}

Source: Ministry of Agriculnure and Rural Development. 
Table 5. Madagascar: Rice Production, Imports, and Availability, 1981-2001

\begin{tabular}{|c|c|c|c|c|c|c|}
\hline & \multirow{2}{*}{$\begin{array}{l}\text { Population' } \\
\text { (Thousands) }\end{array}$} & $\begin{array}{c}\text { Paddíy } \\
\text { Production }\end{array}$ & $\begin{array}{r}\text { Stociks } \\
\text { (End of year) } \\
\end{array}$ & $\begin{array}{c}\text { Net imports } \\
\text { (Exports }- \text { ) }\end{array}$ & $\begin{array}{l}\text { Total Rice } \\
\text { Available } \\
\end{array}$ & \multirow{2}{*}{$\begin{array}{c}\text { Avoilability } \\
\text { (Kilograms/person) }\end{array}$} \\
\hline \multicolumn{5}{|c|}{ (in thousands of metric tons) } & & \\
\hline 1981 & 8,877 & $2,0: 2$ & 8 & 193 & 1.278 & 144 \\
\hline 1982 & 9,109 & 1,970 & 138 & 351 & 1,290 & 142 \\
\hline 1983 & 9,348 & 2,147 & 122 & 185 & 1,365 & 146 \\
\hline 1984 & 9,592 & 2,131 & 47 & $11:$ & 1,343 & 140 \\
\hline 1985 & 9,843 & 2,060 & 0 & 107 & 1.409 & 143 \\
\hline 1986 & 10,100 & 2,116 & 28 & 162 & 1,424 & 141 \\
\hline 1987 & 10,364 & 2,178 & 37 & 94 & 1,433 & 138 \\
\hline 1988 & 10,635 & 2,149 & 13 & 37 & 1,385 & 130 \\
\hline 1989 & 10,933 & 2,380 & 28 & 89 & 1,547 & 141 \\
\hline 1990 & 11,239 & 2,420 & 28 & 76 & 1,574 & 140 \\
\hline 1991 & 11,554 & 2,342 & 30 & 39 & 1,525 & 132 \\
\hline 1992 & 11,877 & 2,450 & 38 & 59 & 1,568 & 132 \\
\hline 1993 & 12,239 & 2,550 & 40 & 5 & 1,581 & 129 \\
\hline 1994 & 12,596 & 2,357 & $\$ 3$ & 159 & 1,605 & 128 \\
\hline 1995 & 12,990 & 2,450 & 62 & 123 & 1,593 & 123 \\
\hline 1996 & 13,393 & 2,500 & 56 & 19 & 1,519 & 114 \\
\hline 1997 & 13,803 & 2,558 & $\cdots$ & 56 & 1,663 & 121 \\
\hline 1998 & 14,222 & 2,447 & $\ldots$ & 58 & 1,619 & 114 \\
\hline 1999 & 14,650 & 2,570 & $\cdots$ & $1 ! 5$ & 1,647 & 112 \\
\hline 2000 & 15,085 & 2.480 & $\cdots$ & 207 & 1,698 & 112 \\
\hline 2001 & 15,529 & 2,662 & $\ldots$ & 158 & $1,7.46$ & $1 \pm 2$ \\
\hline
\end{tabular}

Sources: Ministry of Agriculture and Rural Development; and National Institute of Statistics (INSTAT).

'May differ from data provided by other sources.

${ }^{2}$ Madagascar was a net exporter of rice until 1970 (except for 1965).

${ }^{3}$ Domestic paddy production converted to rice equivalest phus net change in stocks and net imports. 
Table 6. Madagascar: Retail Prices of Ordinary Rice, 1997-2001 (In Malagasy francs per kilogram)

\begin{tabular}{|c|c|c|c|c|c|}
\hline & & \multirow[b]{2}{*}{ Free Market } & \multicolumn{3}{|c|}{ Official } \\
\hline & & & Grocery/ Shop & Distribution & Avcrage Price \\
\hline \multicolumn{6}{|l|}{1997} \\
\hline & Marcl & 2,128 & 2,056 & 2,150 & 2,105 \\
\hline & June & 1,608 & 1,619 & 1,950 & 1,640 \\
\hline & September & 1.876 & 1,906 & 2,036 & 1,892 \\
\hline & December & 2,089 & 2,006 & 2,200 & 2,092 \\
\hline \multicolumn{6}{|l|}{1998} \\
\hline & March & 2,125 & 2,071 & 2,167 & 2,128 \\
\hline & June & 1,875 & 2,000 & 2,172 & 1,877 \\
\hline & September & 1,979 & 1,992 & 2,225 & 1,983 \\
\hline & December & 2,450 & 2,514 & 2,417 & 2,468 \\
\hline \multicolumn{6}{|l|}{1999} \\
\hline & March & 2,473 & 2,543 & 2,526 & 2,508 \\
\hline & June & 2,178 & 2,200 & 2,434 & 2,197 \\
\hline & September & 2,267 & 2,291 & 2,354 & $2,2,83$ \\
\hline & December & 2,379 & 2,383 & 2,465 & 2,381 \\
\hline \multicolumn{6}{|l|}{2000} \\
\hline & March & 2,552 & 2,449 & 2,390 & 2,499 \\
\hline & June & 2,309 & 2,288 & 2,456 & 2,300 \\
\hline & September & 2,605 & 2,583 & 2,602 & 2,594 \\
\hline & December & 2,877 & 2,933 & 2,659 & 2,905 \\
\hline \multicolumn{6}{|l|}{2001} \\
\hline & March & 2,974 & 3,006 & $\ldots$ & 2,990 \\
\hline & June & 2,303 & 2,165 & $\ldots$ & 2,234 \\
\hline & September & 1,975 & 1,998 & $\ldots$ & 1,987 \\
\hline & December & 2,816 & 2,767 & $\ldots$ & 2,792 \\
\hline
\end{tabular}

Source: National Institute of Statistics (INSTAT).

${ }^{1}$ The data refer to the price of rice sold from the food security stock, or Stock Tampon. 
Table 7. Madagascar: Production of Major Cash Crops, 1997-2001

(In thonsands of tons)

\begin{tabular}{|c|c|c|c|c|c|c|}
\hline & & 1997 & 1998 & 1999 & 2000 & 2001 \\
\hline \multicolumn{7}{|l|}{ Export crops } \\
\hline \multirow[t]{2}{*}{ Coffee $^{2}$} & Production & 55.0 & 60.0 & 65.0 & 58.1 & 64.5 \\
\hline & Marketed & 52.0 & 53.0 & 57.2 & $\cdots$ & $\cdots$ \\
\hline \multirow[t]{2}{*}{ Vanilla } & Production ${ }^{3}$ & 4.3 & 5.0 & 5.4 & 4.4 & 4.6 \\
\hline & Marketed $^{4}$ & 1.1 & 1.1 & 1.2 & $\ldots$ & .. \\
\hline \multirow[t]{2}{*}{ Cloves } & Production & 14.5 & 13.5 & 12.5 & 11.8 & 11.8 \\
\hline & Marketed & 15.0 & 15.0 & 11.2 & $\ldots$ & $\ldots$ \\
\hline \multirow[t]{2}{*}{ Pepper } & Production & 1.5 & 1.7 & 1.6 & 1.6 & 1.6 \\
\hline & Marketed & 1.5 & 1.7 & 1.8 & $\ldots$ & $\ldots$ \\
\hline \multirow[t]{2}{*}{ Cocoa } & Production & 4.3 & 4.3 & 4.3 & 4.4 & 4.4 \\
\hline & Marketed & 4.3 & 4.3 & 4.1 & $\ldots$ & $\ldots$ \\
\hline \multirow[t]{2}{*}{ Butter beans } & Production & 8.0 & 7.8 & 8.0 & 7.5 & 7.4 \\
\hline & Marketed & 7.8 & 7.0 & 7.0 & $\cdots$ & $\cdots$ \\
\hline Sisal & Production ${ }^{s}$ & 18.0 & 18.0 & 17.0 & 17.1 & 17.1 \\
\hline \multicolumn{7}{|c|}{ Industrial creps } \\
\hline Cotton $^{6}$ & Production ${ }^{5}$ & 36.2 & 38.6 & 34.6 & 27.4 & 26.5 \\
\hline \multirow[t]{2}{*}{ Sugarcane } & Production & $2,160.0$ & $2,180.0$ & $2,180.0$ & $2,188.6$ & $2,208.5$ \\
\hline & Markeied & $1,500.0$ & $1,500.0$ & $1,504.0$ & $\cdots$ & $\ldots$ \\
\hline \multirow[t]{2}{*}{ Groundinuts } & Production & 35.8 & 34.0 & 34.5 & 35.0 & 35.2 \\
\hline & Marketed & 29.0 & 29.0 & 29.3 & $\ldots$ & $\ldots$ \\
\hline
\end{tabular}

Source: Ministry of Agriculture and Rural Development.

'Data on total production are approxinnate; those on marketed production are more accurate.

${ }^{2}$ Unroasted coffee.

${ }^{3}$ Green vanilla.

${ }^{4}$ Prepared vanilla (4.6 kilograms grcen $=1$ kilogram prepared).

${ }^{5}$ Most of the production is marketed.

${ }^{6}$ Sced cotton, 
Table 8. Madagascar: Indicative Minimum Producer Prices for Major Crops, 1997-2001 ${ }^{1}$

(In Malagasy francs per kilogram)

\begin{tabular}{|c|c|c|c|c|c|c|}
\hline & $\begin{array}{l}\text { Type } \\
\text { of Price }\end{array}$ & 1997 & 1998 & 1999 & 2000 & 2001 \\
\hline Paddy $^{1}$ & Indicative & 858 & 1,070 & 1,100 & 1,290 & $\ldots$ \\
\hline Coffee & Indicative & $3,000-5,000$ & 6,500 & 5,500 & 2,650 & $\ldots$ \\
\hline Cloves & Indicative & 9000 & 9,000 & 23,000 & 24,875 & $\ldots$ \\
\hline Vanilla & Indicative & $5,000-10,000$ & 10,500 & 25,000 & 66,250 & $\ldots$ \\
\hline Sugarcate & Indicative & 700 & 750 & 800 & $\ldots$ & $\ldots$ \\
\hline Pcpper & Indicative & $\ldots$ & 3,033 & 5,000 & 9,875 & $\ldots$ \\
\hline Wheat & Indicative & 1,150 & 1,200 & 1,250 & 1,250 & $\ldots$ \\
\hline Soya beans & Indicative & 1,500 & 1,600 & 1,500 & $\ldots$ & $\ldots$ \\
\hline Cotton & Indicative & $\ldots$ & 2,075 & 1,784 & 1,800 & $\ldots$ \\
\hline
\end{tabular}

Sources: Ministry of Agriculturc and Rural Developnent until 1997; thereafter, National Institute of Statistics (INSTAT).

' The fixing of produccr prices was abolished in 1986. Official indicative minimum prices have been announced since I987; however, all prices are market determined. 
Table 9. Madagascar: Index of Industrial Production, Excluding the Export Processing Zone, 1997-200I

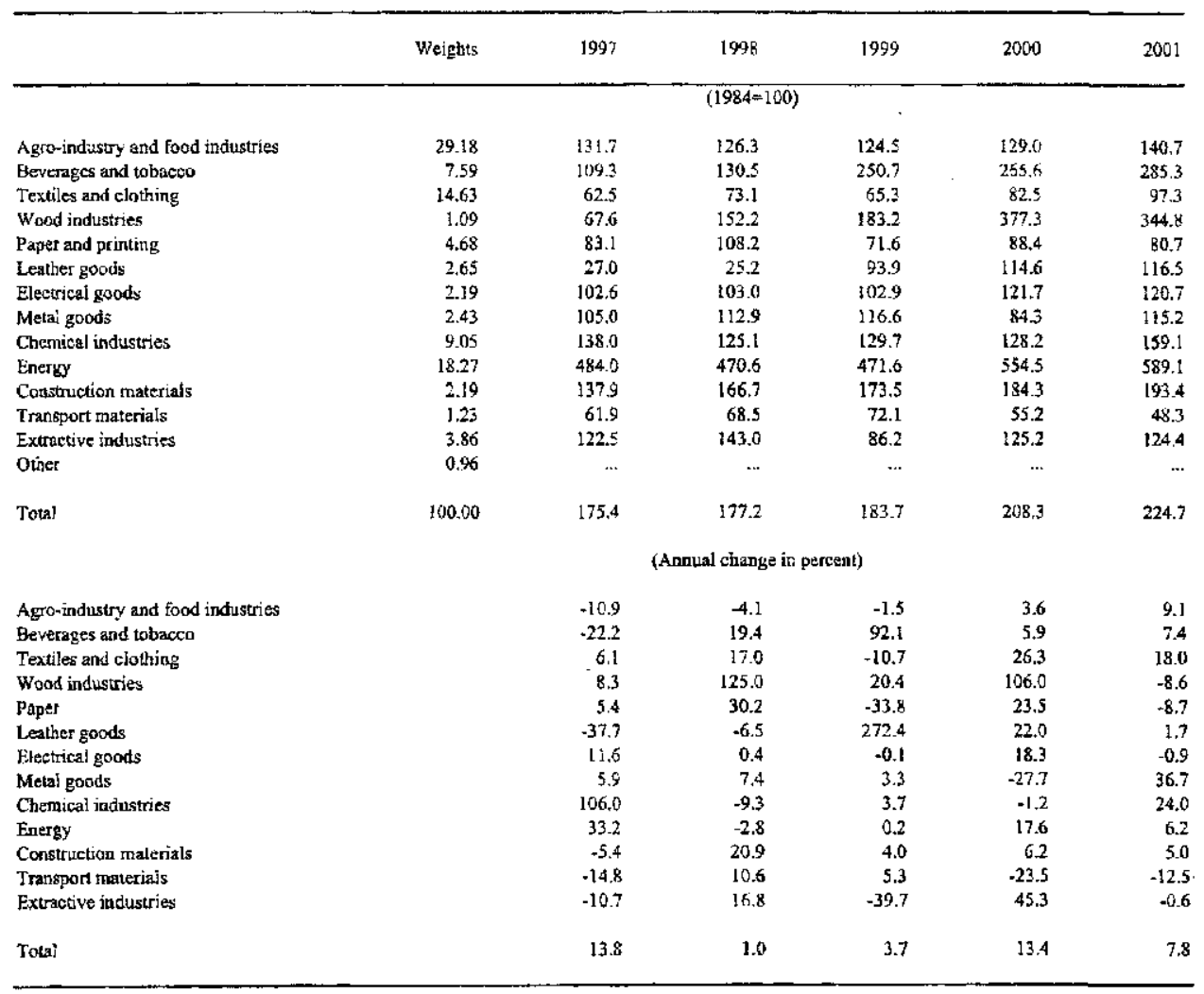

Surees: Ministry of Industry; and Ministry of Evergy and Mining, 
Trble 10. Madag̣asca:: Inłagriaj Production, 1997-2001

\begin{tabular}{|c|c|c|c|c|c|c|}
\hline & Un:ts & 1997 & 1998 & 1999 & 2000 & $\begin{array}{l}2001 \\
\text { Pтov, }\end{array}$ \\
\hline \multicolumn{7}{|l|}{ Extractive industries } \\
\hline Graphite & Tons & 14,107 & 20,629 & 16,137 & 40,328 & 2,013 \\
\hline Mica & Tons & 1,529 & 1,272 & 54 & 66 & 90 \\
\hline Chromit: & Tans & 139.471 & 134.659 & 144 & 131,293 & 23,637 \\
\hline \multicolumn{7}{|l|}{ Fond industries } \\
\hline Tspieca & Toas & 309 & 287 & 296 & 305 & 313 \\
\hline Earato flour & Tons & $\ldots$ & $\ldots$ & $\ldots$ & $\ldots$ & $\ldots$ \\
\hline Catt]c (s/augh:ered industrially) & Head & 8,436 & 4,219 & 4,122 & 4,027 & $4,92 ?$ \\
\hline Hogs (staughtered industristly) & Head & 373 & 428 & 418 & 409 & 468 \\
\hline Carrod meat & Tons & 23 & 2) & 21 & 21 & 15 \\
\hline Ougked pork meats & Tons & $\ldots$ & $\ldots$ & $\ldots$ & $\ldots$ & $\ldots$ \\
\hline Sugs: & Tons & 74,280 & 60,273 & 01,370 & 62,487 & 67,917 \\
\hline Edible oils & Tons & $\therefore, 439$ & 1.280 & $1,33)$ & 1,354 & 1,551 \\
\hline Bect & Hecioliter: & 233.520 & 297,407 & 610,074 & $645, \$ 36$ & 691.661 \\
\hline Condentsed milk & Tons & 2,244 & 2,285 & 1,355 & 1.121 & 1,142 \\
\hline Sal: & Tons & 36,763 & 26.746 & 26,131 & 25,530 & 25,928 \\
\hline \multicolumn{7}{|l|}{ Tobecco } \\
\hline Chewing tobarco & Toxs & $: \pi$ & 299 & 60 & 66 & 56 \\
\hline Smoking tojactoo & Toos & 6 & $\ldots$ & $\ldots$ & $\cdots$ & $\ldots$ \\
\hline Cigarettes & Tous & 2,826 & 3.303 & 3,839 & 4.139 & $4,44 i$ \\
\hline \multicolumn{7}{|l|}{ Textiles } \\
\hline Catron cloth & 1,000 metexs & 26,935 & 19,582 & 20.368 & 2,328 & 29,641 \\
\hline Bags for packaging & Tons & 438 & 506 & 259 & 252 & 364 \\
\hline Blarkets & Ton: & 1,460 & 1,675 & 1.610 & 1,587 & 1,662 \\
\hline String & Tons & 1,500 & 1.570 & 5,641 & 1,510 & 1,607 \\
\hline \multicolumn{7}{|l|}{ Beper } \\
\hline Rag paper & Tons & 4.646 & 6,732 & 3,270 & 5,672 & 4,059 \\
\hline finisbed paper & Tons: & 969 & 1,169 & $\ldots$ & $\cdots$ & ... \\
\hline \multicolumn{7}{|l|}{ Ohezaical industries } \\
\hline Sanp & Tons & 15.125 & 14,513 & 15,884 & 15,385 & 15,915 \\
\hline Accumulators & Units & 4,597 & 3,751 & 4,599 & 3,693 & 3,511 \\
\hline Candles & Tons & 632 & 744 & 743 & 928 & 950 \\
\hline Paint & Tons & 2.258 & 2.131 & 1,918 & 1,487 & 1,554 \\
\hline Balleries & 5,600 units & 25,366 & 25,166 & 25,246 & 30,631 & 30,433 \\
\hline Oxygen & Cubic meters & 524,855 & 540,585 & 417,642 & 62,832 & 200.046 \\
\hline Acketylane & Cubic moters & 116,524 & 112,451 & 90,663 & 23,191 & 76,698 \\
\hline \multicolumn{7}{|l|}{ Petroleum refiniug } \\
\hline Butrasc & Dubic meters & 10,861 & 7,831 & 9,639 & 11,864 & 12,657 \\
\hline Gasoline & Cubic metern & 102,783 & 92,694 & 93,010 & 122,567 & 128,279 \\
\hline Kerosene & Cubic meters & 76.293 & 75,413 & 65,038 & 65,228 & 75,105 \\
\hline Gus vil & Cubic menters & 128,982 & 110,784 & 119.039 & 150,434 & 150,172 \\
\hline FuteI oil & Cuoic netrets & 206,645 & 217,764 & 198,848 & 225,684 & 247221 \\
\hline \multicolumn{7}{|l|}{ Construction muterials } \\
\hline Cement & Tons & 36,217 & 44,327 & $45,70 \mathrm{t}$ & 50,938 & 51,882 \\
\hline \multicolumn{7}{|l|}{ Metal works } \\
\hline Sheet meral & Tons & 6.102 & 6,478 & 6,821 & 4,002 & 6,484 \\
\hline Trunks and boxes & Tous & tos & 509 & 536 & 536 & $\$ 36$ \\
\hline \multicolumn{7}{|l|}{ Shoes } \\
\hline Leather & 1,000 pairs & 126 & $\cdots$ & $\ldots$ & $\ldots$ & $\ldots$ \\
\hline Plastic & 1,000 paits & $\$ 20$ & 396 & 375 & 303 & 291 \\
\hline Othe: & 1,000 pajzs & 330 & $\cdots$ & $\ldots$ & $\cdots$ & $\ldots$ \\
\hline \multicolumn{7}{|l|}{ Elcotricity } \\
\hline Hydraulic & 1,000 kilow-ztt-houkes & 488,700 & 510,646 & 515,374 & 539,649 & 563,963 \\
\hline Thermal & $3,0 \times 0$ kifowatt- bours & $\$ 27.800$ & 154,774 & 205,920 & 240,198 & 269,976 \\
\hline
\end{tabular}

Sources: Ministry of lodustry; and Ministry of Eacrgy and Minitg 
Table 11. Madagascar: Economic Activities of Manufacturing Enterprises in the Export Processing Zone (EPZ), 1997-2001

\begin{tabular}{|c|c|c|c|c|c|c|c|c|c|c|}
\hline & & & & & & \multirow{2}{*}{\multicolumn{3}{|c|}{$\begin{array}{l}\text { Cumulative EPZ } \\
\text { Charters Granted }\end{array}$}} & \multicolumn{2}{|c|}{ Total Commitments, 1990-2001 ${ }^{1}$} \\
\hline & \multicolumn{5}{|c|}{ EPZ Charters Granted } & & & & \multirow{2}{*}{$\begin{array}{l}\text { Employment } \\
\text { (Individuals) }\end{array}$} & \multirow{2}{*}{$\begin{array}{r}\text { Investment } \\
\text { (In billions of } \\
\text { Malagasy francs) }\end{array}$} \\
\hline & 1997 & 1998 & 1999 & 2000 & 2001 & 1999 & 2000 & 2001 & & \\
\hline \multicolumn{11}{|l|}{ Sectors } \\
\hline Agro-food processing & 3 & 2 & 0 & 1 & 1 & 31 & 32 & 33 & 3,106 & 113.6 \\
\hline Textiles & 15 & 76 & 5 & 14 & 15 & 129 & 143 & 158 & 68,649 & 615.7 \\
\hline Hîdes and skins & 1 & -1 & 1 & 0 & 0 & 6 & 6 & 6 & 761 & 12.1 \\
\hline Wood processing & 1 & 4 & 1 & 0 & 0 & 22 & 22 & 22 & 1,589 & 43.0 \\
\hline Data processing & 5 & 1 & 2 & 0 & 0 & 28 & 28 & 28 & 2,213 & 20.9 \\
\hline Chemicals & 3 & -1 & I & 0 & 2 & 9 & $y$ & 11 & 673 & 31.4 \\
\hline Electrical and mechanical & 0 & 0 & 0 & 0 & 0 & 4 & 4 & 4 & 129 & 5.0 \\
\hline Mineral processing & 0 & -1 & 1 & 0 & 0 & 6 & 6 & 6 & 424 & 32.5 \\
\hline Iandicrafts & 1 & -1 & 1 & $\theta$ & 1 & 16 & 16 & 17 & 2,960 & 1.3 .7 \\
\hline Jewelry & 2 & -1 & 1 & 0 & 0 & 12 & 12 & 12 & 519 & 11.8 \\
\hline Enterprises promating and & 1 & 6 & -1 & 0 & 3 & 3 & 3 & 6 & 142 & 28.0 \\
\hline managing EPZs & 0 & 0 & 0 & 1 & 0 & 1 & 2 & 2 & 106 & 520.3 \\
\hline Total & 32 & 84 & 12 & 16 & 24 & 267 & 283 & 305 & 81,271 & $1,447.9$ \\
\hline
\end{tabular}

Source: Ministry of Industry.

${ }^{1}$ Cumulative totals of investment and employment commitruents indicated in proposals and business plans of EPZ charter applications. 
Table 12. Madagascar: Number of Enterprises with Operating Permits Under the Export Processing Zone Regime. 1997-2001

\begin{tabular}{|c|c|c|c|c|c|}
\hline & 1997 & 1998 & 1999 & 2000 & 2001 \\
\hline Number of manufacturing enterprises operating under EPZ & 241 & 259 & 267 & 283 & 307 \\
\hline (in percent) ${ }^{l}$ & 1.5 & $\cdots$ & $\ldots$ & $\ldots$ & $\ldots$ \\
\hline Textiles and hides & 120 & 127 & 135 & 149 & 164 \\
\hline Wood processing & 18 & 22 & 22 & 22 & 22 \\
\hline Food, beverages, and tobacco & 29 & 31 & 31 & 32 & 33 \\
\hline Other (mainly jewelry and handicrafts) & 74 & 79 & 79 & 80 & 88 \\
\hline Total number of employees & 38,400 & 56,200 & 64,100 & 81,000 & 110,000 \\
\hline (in percent) $^{\mathrm{i}}$ & 20.2 & 24.1 & 25.8 & 27.5 & 29.5 \\
\hline Wages paid (in billions of Malagasy francs) & 117 & 176 & 202 & 237 & 332 \\
\hline (in percent) ${ }^{\prime}$ & 17.9 & 20.5 & $\cdots$ & $\cdots$ & $\ldots$ \\
\hline Value added (in billions of Malagasy francs) & 250 & 304 & 328 & 360 & 447 \\
\hline (in percent) $)^{\prime}$ & 12.6 & 13.1 & $\cdots$ & $\cdots$ & $\cdots$ \\
\hline Exports (in billions of Malagasy franes) & 747 & 1,031 & 1,157 & 1,236 & 1,368 \\
\hline (in percent) $^{3}$ & 49.9 & 54.7 & $\cdots$ & $\ldots$ & \\
\hline Imports (in billions of Malagasy francs) & 370 & 468 & 512 & 599 & 735 \\
\hline (in percenl) $^{1}$ & 21.9 & 27.7 & $\ldots$ & $\ldots$ & $\cdots$ \\
\hline
\end{tabular}

Source: Project Madio, Le Secteur Industriel Formel à Madagascar: Caractéristiques, Performances,

Perspectives, various issues, 1995-97.

' In percent of the total for the manufacluring sector. 
Table 13. Madagascar: Production and Export of Major Minerals, 1997-2001

\begin{tabular}{llllll}
\hline & 1997 & 1998 & 1999 & 2000 & 2001 \\
& & & & & \\
\hline
\end{tabular}

Production (thousands of tons)

$\begin{array}{lrrrrr}\text { Chromite } & 139.5 & 134.7 & 0.1 & 131.3 & 23.6 \\ \text { Graphite } & 14.1 & 20.6 & 16.1 & 40.3 & 2.0\end{array}$

Exports (thousands of tons)

$\begin{array}{lrrrrr}\text { Chromite } & 134.0 & 115.2 & 81.5 & 70.0 & 33.5 \\ \text { Graphite } & 15.3 & 9.9 & 14.1 & 16.8 & 11.3\end{array}$

Export value (millions of SDRs)

$\begin{array}{llllll}\text { Chromite } & 6.1 & 5.9 & 3.2 & 4.3 & 1.2 \\ \text { Graphite } & 5.2 & 3.7 & 4.3 & 5.3 & 3.7\end{array}$

Unit value (SDRs per ton)

\begin{tabular}{lrrrrr} 
Chromite & 45.5 & 51.3 & 39.8 & 60.8 & 36.2 \\
Graphite & 340.7 & 367.5 & 305.3 & 316.2 & 330.7 \\
\hline
\end{tabular}

Source: Ministry of Energy and Mining. 
Table 14. Madagascar: Tourism Indicators, 1997-2001

\begin{tabular}{|c|c|c|c|c|c|}
\hline & 1997 & 1998 & 1999 & 2000 & 2001 \\
\hline Number of tourists & 100,762 & 121,207 & 138,253 & 160,071 & 170,208 \\
\hline Annual growth in percent & 21.9 & 20.3 & 14.1 & 15.8 & 6.3 \\
\hline Hotel capacity (number of rooms) & 6,246 & 6,637 & 7,207 & 7,779 & 8,435 \\
\hline Average capacity utilization (in percent) ${ }^{1}$ & 57 & 58 & 60 & 63 & 66 \\
\hline Number of tourist uights (in thousands) & $1,410,668$ & $2,302,933$ & $2,626,807$ & $3,041,349$ & $3,233,952$ \\
\hline Annual growth in percent & 21.9 & 63.3 & 14.1 & 15.8 & 6.3 \\
\hline Average length of stay (days) & 15 & 20 & 20 & 20 & 20 \\
\hline \multicolumn{6}{|l|}{ Foreign exchange receipts from tourism } \\
\hline (in millions of SDRs) & 52.9 & 65.5 & 72.9 & 92.0 & 90.2 \\
\hline Annual growth in percent & 18.6 & 23.8 & 11.3 & 26.2 & -2.0 \\
\hline
\end{tabular}

Source: Ministry of Transportation, Meteorology, and Tourism; Directorate of Tourism.

'Survey coverage is not complete. 
Table 15. Madagascar: Production and Consumption of Electricity, 1997-2001 (In millions of kilowatt-hours)

\begin{tabular}{|c|c|c|c|c|c|}
\hline & 1997 & 1998 & 1999 & 2000 & 2001 \\
\hline Production $^{1}$ & 616.3 & 665.4 & 721.3 & 779.8 & 833.9 \\
\hline Hyóroelectric & 488.7 & 510.6 & 515.4 & 539.6 & 564.0 \\
\hline Thermal & 127.6 & 154.8 & 205.9 & 240.2 & 270.0 \\
\hline Consumption & 485.4 & 524.4 & 571.5 & 616.5 & 644.2 \\
\hline Public lighting & 7.7 & 8.0 & 8.3 & 8.8 & 9.3 \\
\hline Househoids & 200.0 & 225.3 & 253.6 & 281.3 & 298.2 \\
\hline Other & 277.8 & 291.1 & 309.5 & 326.4 & 336.7 \\
\hline
\end{tabular}

Source: Ministry of Energy and Mining.

'Electric power generated by the electricity and water company, that is, excluding electricity generated by industries for their own consumption. 
Table 16. Madagascar; Prices of Petroleum Products, 1997-2001 '

(In Malagasy francs per liter, unless otherwise indicated)

\begin{tabular}{|c|c|c|c|c|c|}
\hline & $\begin{array}{l}\text { Gasoline } \\
\text { (Regular) }\end{array}$ & $\begin{array}{c}\text { Gasoline } \\
\text { (Premium) }\end{array}$ & Gas Oil & Kerosene & Natural Gas ${ }^{2}$ \\
\hline 1997 March & 1,913 & 2,236 & 1,553 & 1,420 & 34,000 \\
\hline June & 2,000 & 2,383 & 1,650 & 1,500 & 34,000 \\
\hline September & 2,000 & 2,383 & 1,650 & 1,450 & 34,000 \\
\hline December & 2,000 & 2,383 & 1,650 & 1,450 & 34,000 \\
\hline 1998 March & 2,106 & 2,530 & 1,727 & 1,450 & 42,000 \\
\hline June & 2,090 & 2,530 & 1,700 & 1,450 & 42,000 \\
\hline September & 2,090 & 2,530 & 1,700 & 1,450 & 42,000 \\
\hline December & 2,090 & 2,530 & 1,700 & 1,450 & 42,000 \\
\hline 1999 March & 2,090 & 2,530 & 1,700 & 1,460 & 45,000 \\
\hline June & 2,290 & 2,910 & 1,770 & 1,520 & 55,000 \\
\hline Septcrnber & 2,480 & 3,350 & 1,840 & 1,630 & 55,000 \\
\hline December & 2,950 & 3,980 & 2,110 & 1,850 & 55,000 \\
\hline $2000 \mathrm{March}$ & 3,139 & 4,408 & 2,232 & 2,100 & 55,000 \\
\hline June & 3,400 & 5,000 & 2,400 & 2,100 & 55,000 \\
\hline September & 3,750 & 5,100 & 2,750 & 2,300 & 55,000 \\
\hline December & 4,200 & 5,500 & 3,000 & 2,500 & 76,000 \\
\hline 2001 March & 4,200 & 5,500 & 3,000 & 2,686 & 76,000 \\
\hline June & 4,533 & 5,583 & 3,000 & 2,656 & 77,000 \\
\hline Septembet & 4,300 & 5,300 & 3,000 & 2,566 & 73,500 \\
\hline December & 4,130 & 5,120 & 2,900 & 2,385 & 73,500 \\
\hline
\end{tabular}

Source: Ministry of Energy and Mining.

'Wholesale prices from storage facilities; retail prices are higher by a small, fixed profit margin.

Prices recorded in the capital city only.

${ }^{2}$ Prices are for a 12.5 kilogram container. 
Table 17. Madagascar: Population and Labor Force, 1997-2001

(In thousands, unless otherwise indicated)

\begin{tabular}{|c|c|c|c|c|c|}
\hline & 1997 & 1998 & 1999 & 2000 & 2001 \\
\hline Population & 13,803 & 14,222 & 14,650 & 15,085 & 15,529 \\
\hline Percentage change & 3.1 & 3.0 & 3.0 & 3.0 & 2.9 \\
\hline Labor force & $\ldots$ & $\ldots$ & $\ldots$ & $\cdots$ & $\ldots$ \\
\hline Agriculture & $\ldots$ & $\ldots$ & $\ldots$ & $\ldots$ & $\ldots$ \\
\hline Manufacturing and mining & $\ldots$ & $\cdots$ & $\ldots$ & $\cdots$ & $\ldots$ \\
\hline Construction & $\ldots$ & $\ldots$ & $\ldots$ & $\ldots$ & $\ldots$ \\
\hline Commerce, banking, and insurance & $\ldots$ & $\ldots$ & $\ldots$ & $\cdots$ & ... \\
\hline Transportation and telecommunications & $\ldots$ & $\ldots$ & $\ldots$ & $\ldots$ & $\ldots$ \\
\hline Administration & $\ldots$ & $\ldots$ & $\ldots$ & $\ldots$ & ... \\
\hline Miscellaneous & $\ldots$ & $\ldots$ & $\ldots$ & $\ldots$ & ... \\
\hline
\end{tabular}

Source: National Institute of Statistics (INSTAT).

'No data have been published by the National Social Sccurity Fund since 1993. 
Tabie 18. Madagascar: Distribution of Population and Civil Servants, 1997-2001 (In percent of total)

\begin{tabular}{|c|c|c|c|c|c|c|}
\hline \multirow[b]{2}{*}{ Region } & \multirow{2}{*}{$\begin{array}{r}\text { Population } \\
1997 \\
\text { Est. }\end{array}$} & \multicolumn{5}{|c|}{ Civil Servants } \\
\hline & & 1997 & 1998 & 1999 & 2000 & $\begin{array}{l}2001 \\
\text { Prov. }\end{array}$ \\
\hline Antananarivo & 29.0 & 43.0 & 42.8 & 42.4 & 43.0 & 44.2 \\
\hline Antsiranana & 7.8 & 6.3 & 6.3 & 6.4 & 6.6 & 6.9 \\
\hline Fianarantsoa & 21.7 & 17.1 & 16.8 & 17.2 & 17.1 & 16.1 \\
\hline Mahajanga & 11.1 & 9.6 & 9.7 & 9.9 & 9.8 & 9.6 \\
\hline Toamasina & 15.8 & 12.8 & 12.8 & 12.7 & 12.6 & 12.4 \\
\hline Toliara & 14.6 & 11.2 & 11.6 & 11.4 & 10.9 & 10.8 \\
\hline Total. & 100.0 & 100.0 & 100.0 & 100.0 & 100.0 & 100.0 \\
\hline
\end{tabular}

Sources: Ministry of Economy, Finance, and Budget; and Fund staff estimates. 
Table 19. Madagascar: Minimum and Maximum Monthly Wages, $1994-2002^{1}$ (In Malagasy francs)

\begin{tabular}{lcccccc}
\hline & \multicolumn{2}{c}{ Agricultural $^{2}$} & & \multicolumn{2}{c}{ Nonagricultural $^{3}$} \\
\cline { 6 - 7 } & Minimum & Maximum & & Minimum & Maximum \\
\hline January 1994 - February 1995 & 64,236 & 158,772 & & 63,313 & 155,997 \\
March 1995 - October 1996 & 112,435 & 244,080 & & 110,550 & 239,993 \\
November 1996 - Febnuary 1998 & 123,778 & 268,704 & & 121,591 & 263,947 \\
March 1998 - May 1999 & 142,280 & 308,880 & & 134,860 & 303,638 \\
June 1999 - February 2000 & 156,514 & 339,768 & & 153,846 & 334,002 \\
March 2000 - December 2000 & 162,583 & 352,944 & & 160,156 & 347,811 \\
January 2001 - March 2001 & 174,800 & 379,200 & & 172,290 & 374,046 \\
Since April 2001 & 182,600 & 396,000 & & 180,090 & 390,859 \\
\hline
\end{tabular}

Source: Ministry of Civil Service.

${ }^{1}$ "Minimum" indicates the minimum wage in the lowest wage category, and "maximum" indicates the minimum wage in the highest wage category.

${ }^{2}$ On the basis of 200 working hours per month.

${ }^{3}$ On the basis of 173.33 working hours per month. 
Table 20. Madagascar: Consumer Price Index by Product, 1997-2000

(period averages unless otherwise indicated; August 1971-July $1972=100$ )

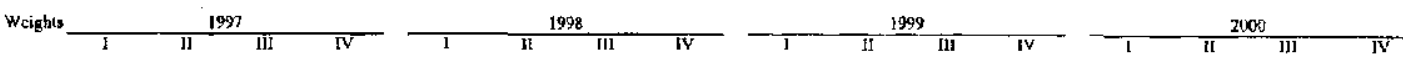

\begin{tabular}{|c|c|c|c|c|c|c|c|c|c|c|c|c|c|c|c|c|c|}
\hline \multicolumn{18}{|l|}{ Traditionel bouschoids ' } \\
\hline Food & 60.35 & 4159 & 4011 & 4019 & 4293 & 4382 & 4312 & 4285 & 4457 & 4674 & 4768 & 4915 & 5272 & 5522 & $\operatorname{sstan}$ & 5533 & 58.15 \\
\hline Lighting and fucl & 9.14 & 3615 & 3626 & 3668 & 3739 & 4042 & 405] & 3550 & $4(0) 4$ & 4001 & 4021 & 4059 & 4089 & $423 i$ & 4398 & 4547 & 4647 \\
\hline Domestic services & 1.82 & 1052 & 1052 & $\ln 2$ & 1052 & 1052 & 1052 & 1052 & 1052 & 1331 & 1331 & 1331 & 1331 & 1331 & 1331 & 1331 & 1331 \\
\hline Mairtonance, stothing, medicine & 14.85 & 3405 & 3475 & 3515 & 3565 & 3674 & 3717 & 3737 & 3753 & 3818 & 3837 & 3908 & 3924 & 3932 & 3940 & 3941 & 3982 \\
\hline Misceilaneous & 13.84 & 4506 & $45 A 1$ & 4483 & 4375 & 4408 & 4707 & 1838 & 4846 & 4899 & 5091 & 5266 & 5407 & 5583 & 5708 & 5773 & 6047 \\
\hline Genetal nitex & $100 \% 0$ & 3989 & 3916 & 3923 & 4087 & 4189 & 4195 & 4191 & 4301 & $\$ 456$ & 4544 & 4671 & 4910 & 5100 & $\$ 126$ & 5160 & 5399 \\
\hline Annual change (in perseni) & $\ldots$ & 6.3 & 2.4 & 4.0 & 5.2 & 5.0 & 7.1 & 6.8 & 5.2 & 6.4 & B.3 & 11.4 & 14.2 & 14.5 & 12.8 & 10.5 & 9.9 \\
\hline \multicolumn{18}{|l|}{ Madero households } \\
\hline Fond & 45.16 & $4 i 37$ & $\$ 144$ & 4322 & 4480 & 4737 & 4968 & 5103 & 5156 & 5264 & 5315 & 5527 & 5592 & 5871 & 6119 & 6072 & 6093 \\
\hline Lightirug and fuel & 6.08 & 2500 & 2500 & 2589 & 2766 & 3133 & 3157 & 3246 & 3308 & 3232 & 3250 & 3494 & 3514 & 3622 & 3702 & 3799 & $\Delta 309$ \\
\hline Domestic services & 11.26 & 1371 & 1371 & 1371 & $137 \mid$ & 1371 & 1371 & 1571 & 1931 & 1732 & 1732 & 1732 & 1732 & 1732 & 1732 & 1722 & 1732 \\
\hline Maintenance, clothing, and medicince & 17.99 & $35 \mathrm{~m}$ & 35.14 & 3663 & 3841 & 3909 & 3955 & 3981 & 4011 & 4127 & 4199 & 4310 & 4386 & 4460 & $45 \$$ & 4568 & 4675 \\
\hline Miscelleneous & 19.51 & 3574 & 3516 & 3542 & 3711 & 3863 & 3767 & 3776 & 3841 & 4038 & 4030 & 4159 & 4467 & 4769 & 4885 & 4934 & 5355 \\
\hline Genetal index & 100.00 & 3503 & 3501 & 3614 & 3761 & 3941 & 4036 & 4109 & 4155 & 4299 & 4334 & 4490 & 4595 & 4799 & 4957 & 4949 & $50 \% 4$ \\
\hline Annual change (in percen) & $\cdots$ & 9.6 & 5.7 & 8.0 & 10.9 & 12.5 & 15.3 & 13.7 & 10.5 & 9.1 & 7.4 & 9.3 & 10.6 & 11.6 & 14.4 & 10.2 & 10.9 \\
\hline Cornbined consumer price inder $x^{2}$ & 100.00 & 3867 & 3812 & 3845 & 4005 & 4127 & 4155 & 4171 & 42 iss & 4416 & 4491 & 4626 & 4831 & so2s & 5083 & 5107 & 5323 \\
\hline
\end{tabular}

Snbroe: Mational tastituic of Statislites (INSTAT)

'Low.income housetrolds.

${ }^{2}$ Weights or 0.75 and 0.25 are applied to the index of traditionat households and to the index of umilem bouscholds, respectively. 
Table 21. Madagascar: New Consumer Price Index by Product, $2001^{1}$

\begin{tabular}{|c|c|c|c|c|c|}
\hline \multirow[b]{2}{*}{$\therefore$} & \multirow[b]{2}{*}{ Weight } & \multicolumn{4}{|c|}{2001} \\
\hline & & 1 & II & П!I & IV \\
\hline & & \multicolumn{4}{|c|}{ Period averages; January 2000 - December $2000=100$ ) } \\
\hline General index & 10,000 & 108.4 & 105.8 & 106.2 & 109.2 \\
\hline Foodstuffs, beverage and tobacco & 4,965 & 109.7 & 102.6 & 95.6 & 99.4 \\
\hline Clothing & 679 & 104.8 & 106.6 & 110.8 & 108.7 \\
\hline Shelter, water, lighting, gas, and other fuel & 1,860 & 106.8 & 107.0 & 115.9 & 117.8 \\
\hline Furniture, household cquipment, and maintenance & 456 & 103.3 & 107.9 & 111.7 & 111.7 \\
\hline Health & 240 & 104.8 & 107.1 & 110.5 & 110.8 \\
\hline Transportation & 829 & 112.9 & 116.1 & 128.2 & 134.3 \\
\hline Entertaimment and culture & 245 & 101.8 & 103.5 & 116.8 & 119.1 \\
\hline Education & 396 & 109.8 & 113.7 & 123.5 & 129.3 \\
\hline Hotel and restaurant & 151 & 101.1 & 101.3 & 102.6 & 102.3 \\
\hline \multirow[t]{3}{*}{ Other goods and services } & 179 & 104.4 & 108.9 & 112.3 & 115.6 \\
\hline & & \multicolumn{4}{|c|}{ (Annual percentage change) } \\
\hline & & 10.0 & 6.7 & 6.3 & 5.0 \\
\hline Foodstuffs, beverage and tobacco & & 9.1 & 2.3 & -4.3 & -4.6 \\
\hline Clothing & & 11.9 & 9.7 & 9.7 & 7.2 \\
\hline Shelter, water, lighting, gas, and other fuel & & 10.2 & 9.8 & 18.1 & 16.0 \\
\hline Furniture, Household Equipment, Maintenance & & 2.0 & 5.9 & 9.7 & 9.2 \\
\hline Health & & 4.4 & 6.1 & 8.2 & 6.8 \\
\hline 'Transportation & & 23.0 & 20.4 & 27.0 & 21.8 \\
\hline Entertainment and culture & & 8.1 & 10.3 & 20.7 & 18.4 \\
\hline Education & & 17.4 & 19.0 & 22.4 & 18.7 \\
\hline Holel and restaurant & & -0.1 & -2.1 & 0.3 & 0.0 \\
\hline Other goods and services & & 10.8 & 14.3 & 15.9 & 15.1 \\
\hline
\end{tabular}

Source: National Institute of Statistics (NSlAT).

${ }^{1}$ Since 2001. 
Table 22. Madagascar: Central Goveroment Fizancial Opcrations, 1997.2001 (lin billions of Malagasy franas)

\begin{tabular}{|c|c|c|c|c|c|}
\hline & 1997 & 1998 & 1499 & 2000 & 2001 \\
\hline Total revenue and grants & $2,705.2$ & $2,872.6$ & 3.509 .9 & $4,0) ! 4.4$ & $4.190,6$ \\
\hline Totsl teventas & $3,746.8$ & 2.364 .8 & $2,667,4$ & $3,067,7$ & $3,029.0$ \\
\hline Budgetary revente & $j, 746.8$ & 2.076 .8 & $2,667.4$ & 3.067 .7 & $3,029.0$ \\
\hline Of whict: tax severue & $: .687 .9$ & $1,984.4$ & $2,580.1$ & $2,972.1$ & $2,906.4$ \\
\hline Extrabudgetaty and capital reverue & 0.0 & 0.0 & $\theta n$ & 0.0 & 0.0 \\
\hline Grants & 956,5 & 707.8 & 842.5 & 946.7 & $1,16 !, 6$ \\
\hline Curren: grants & 377.7 & 59.8 & 171.9 & 178.9 & 427.7 \\
\hline Project grants & 578.8 & 648.0 & 670.6 & 767.8 & 733.9 \\
\hline Tutal expenditure & $3,137.1$ & $3,819.3$ & 3.790 .9 & $4,168.6$ & $5,262,6$ \\
\hline Cument cxpanditane & $1,960,2$ & $2,146.1$ & $2.175,0$ & $2,402.5$ & $3,081.7$ \\
\hline Budgetary expendinurc & 1.801 .6 & $2,052.1$ & $2,172.4$ & $2,416.5$ & $3,001,0$ \\
\hline Persuninel & 669.6 & 826.4 . & $1,000.6$ & $1,042.4$ & 1.337 .6 \\
\hline Other nouinterest expenditure & 583.0 & $6 ? 1,9$ & 679.0 & 761.8 & $1,071.5$ \\
\hline Foreign interest ubligations & 503.5 & $\$ 66.5$ & 325.0 & 371.2 & 349.1 \\
\hline Domestiv inderest obligationas & $4 \$ .4$ & 89.3 & 167.8 & $24 ! .1$ & 242.8 \\
\hline I reasury operations \{net\} & 120.1 & Y4.i) & 2.6 & -56.5 & 54.3 \\
\hline Emergency expenditure ${ }^{2}$ & 38.5 & 0.0 & 0.0 & 40.6 & 25,0 \\
\hline Conntcrpart funds-financed operations & $\cdots$ & $\cdots$ & $\cdots$ & 2.0 & 1.4 \\
\hline Capital expenditure & $1,176.9$ & $1,673.1$ & $1,6: 5,9$ & $\mathbf{i . 7 6 6 . 1}$ & $2,180,9$ \\
\hline Domestic finanting & 274.5 & 465.6 & 429.6 & 581.2 & 942.3 \\
\hline Foreign financing & 902.0 & $1,207,5$ & $1,186.3$ & 1.184 .9 & $3,238.6$ \\
\hline \multicolumn{6}{|l|}{$\begin{array}{l}\text { Overal) balance (combintmem basis, } \\
\text { excluding the cost of structural reforts:s) }\end{array}$} \\
\hline Lucluding grants & -433.9 & .946 .7 & .281 .0 & -154.2 & $-1,072.0$ \\
\hline Exclucting grants & -1.390 .4 & $-1,654.5$ & $-1,123.5$ & $-1,100.9$ & $-2,233.6$ \\
\hline Net cosl of stuctentral teforms ${ }^{3}$ & 0.0 & .236 .7 & -369.7 & -582.7 & $-223 . i$ \\
\hline Exceptional reveruse & 0.0 & 0.0 & 45.6 & 17.7 & 11.5 \\
\hline Cost of structural reforms & 0.0 & 236.7 & 415.3 & 600.4 & 234.6 \\
\hline $\begin{array}{l}\text { Overall bol ance (commitment iasis, } \\
\text { including the cost of struchural tefortns) }\end{array}$ & & & & & \\
\hline Ineluding grants & -433.9 & $-1,183.4$ & -650.7 & -737.0 & $-1,295.1$ \\
\hline Excluding grants & $-1,390.4$ & -3.891 .2 & -1.493 .2 & $+1.6 \$ 3.7$ & -2.456 .7 \\
\hline Dornestic balance & 15.2 & -217.1 & 18.1 & -127.6 & $-80 \mathrm{~s}, 9$ \\
\hline Charge in artears & $-139,4$ & -101.8 & 67.6 & -135.9 & -27.0 \\
\hline Tatal overall balance (cast basis, including grants) & -573.3 & $-1,285.2$ & $-5 \times 3.1$ & -872.8 & $-1,3220$ \\
\hline Finsucing & 573.3 & $1,285.3$ & 583.1 & 872.8 & $1,322.0$ \\
\hline Foreign (net) & 692.3 & 379.4 & 284.9 & 704.7 & 635.6 \\
\hline Drswings & \pm .029 .3 & 672.5 & 515.7 & 802.4 & 723.4 \\
\hline Buoget & $\ldots$ & $\cdots$ & $\ldots$ & 385.3 & 218.7 \\
\hline Projects & -- & $\ldots$ & $\ldots$ & 417.1 & 504.7 \\
\hline Amortization due & -508.9 & -6621 & -607.5 & -621.5 & -581.0 \\
\hline Change in external arrears & $.5,459.7$ & 88.6 & 27.6 & 49.5 & -68.2 \\
\hline Extcrial debt relief & $5,631.7$ & 280.5 & 349.1 & 573.2 & $56: 3$ \\
\hline Financing gasp & 0.0 & 0.0 & 0.0 & 0.0 & 0.0 \\
\hline Damessic (nes) & -119.0 & 901.5 & 246.4 & 121,9 & 580.9 \\
\hline $\begin{array}{l}\text { Bunking bystem } \\
\text { Nonbunking system }\end{array}$ & $\begin{array}{r}.145 .0 \\
27.0\end{array}$ & $\begin{array}{l}741.2 \\
160.3\end{array}$ & $\begin{array}{r}167.1 \\
79.3\end{array}$ & $\begin{array}{r}3.1 \\
118.8\end{array}$ & $\begin{array}{l}468.4 \\
11.2 .5\end{array}$ \\
\hline Privatization receipts & 0.0 & 4.4 & 51.8 & 46.3 & 30.1 \\
\hline
\end{tabular}

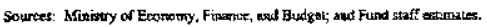

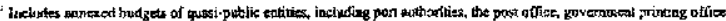

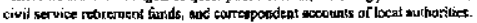

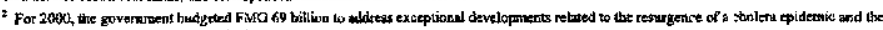
devartating effools of thres cyctiones in lie year.

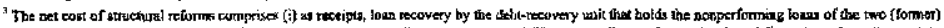

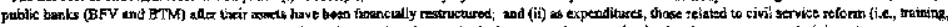

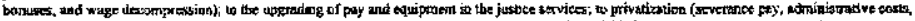

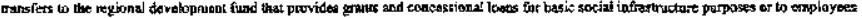

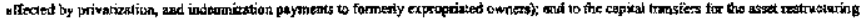
wh the two irsolvent hanks (BFY and BTMT.

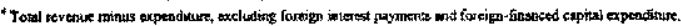


Table 23. Madagascar" Central Gosennmemt Fiscal Inütoalors, 1997-2001 (In pereenl o: GDP, uniess otherwise incica;ed)

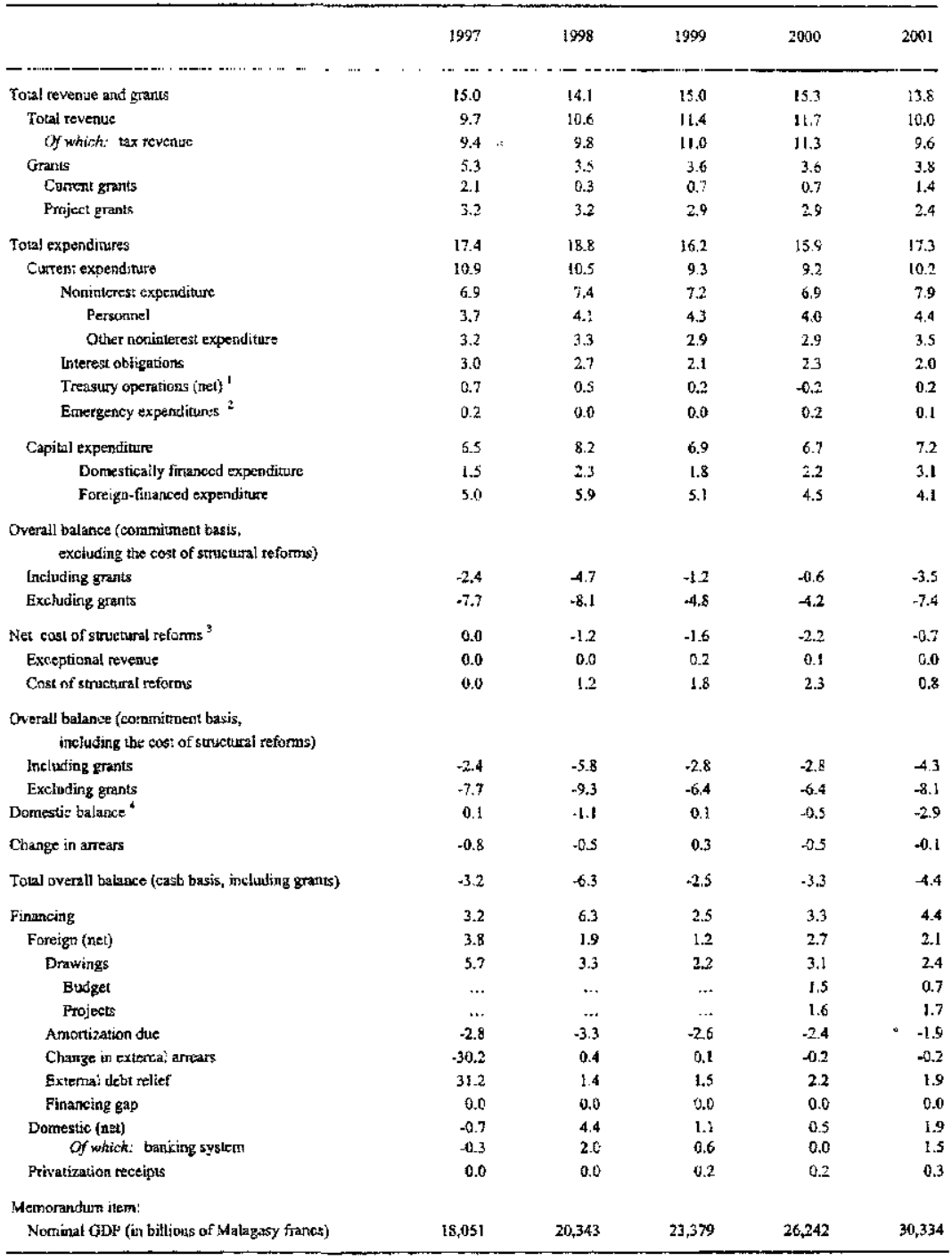

Sources: Ministry of Lconcmy, Finance, and Budxct; and Fund staft octiontess.

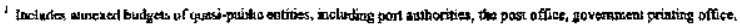

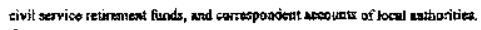

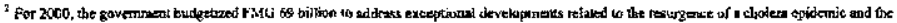
devarationg eflocts of three syclones the year.

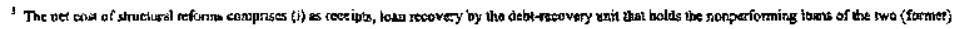

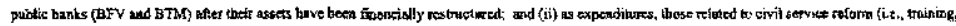

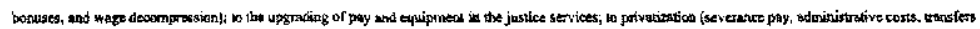

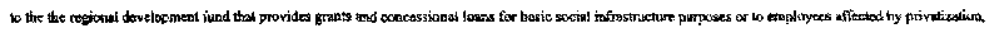

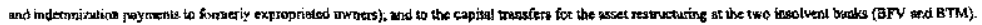

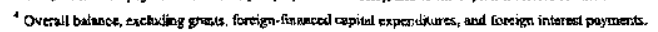


Table 24. Madagascar: Budgetary Revenue, 1997-2001

(In billious of Malagasy franes)

\begin{tabular}{|c|c|c|c|c|c|}
\hline & 1997 & 1998 & 1999 & 2000 & 20091 \\
\hline Tax revenue & 1,688 & 1,984 & 2,580 & 2,972 & 2,906 \\
\hline Taxes on net income & 329 & 340 & 398 & 467 & 595 \\
\hline Companies & 202 & 217 & 207 & 236 & 301 \\
\hline Individuals & 87 & 98 & 190 & 231 & 293 \\
\hline Tax on income (IRNS) & 26) & 26 & 23 & 27 & 38 \\
\hline Tax on wages and salaries (TRSA) & 67 & 72 & 106 & 126 & 166 \\
\hline Other & 4) & 38 & 62 & 78 & 90 \\
\hline Taxes on property & 27 & 23 & 25 & 31 & 34 \\
\hline Taxes on goods and services & 370 & 528 & 662 & 86.5 & 804 \\
\hline Vafue-added tax (VAT) & 178 & 319 & 389 & 513 & 536 \\
\hline Excises & 66 & 78 & 128 & 160 & 110 \\
\hline Fiscal tnonopoly profits & 112 & 117 & 111 & 179 & 146 \\
\hline Other & 14 & 14 & 33 & 33 & 12 \\
\hline Taxes on foreign trate & 948 & 1,241 & $1,48 \mathrm{I}$ & 1,591 & 1,452 \\
\hline Import duties & 941. & 1,241 & 1,481 & 1,591 & 1,452 \\
\hline Customs duty & 132 & 167 & 149 & 123 & 116 \\
\hline Fiscal duty & 235 & 279 & 265 & 241 & 232 \\
\hline VAT on imports & 341 & 478 & 624 & 712 & 722 \\
\hline Petroleum products & 187 & 280 & 340 & 398 & 272 \\
\hline Other & 46 & 38 & 15 & 18 & 6 \\
\hline Export duties & 7 & 0 & 0 & 0 & 0 \\
\hline Export duty & 7 & 0 & 0 & 0 & 0 \\
\hline Expost surcharge & 0 & 0 & 0 & 0 & 0 \\
\hline Other taxes & 15 & 14 & 14 & 18 & 22 \\
\hline Nontax revenue & 59 & 92 & 87 & 96 & 123 \\
\hline Budgetary revenue & 1,747 & 2,077 & 2,667 & 3,068 & 3,029 \\
\hline
\end{tabular}

Source: Ministry of Economy, Fizance, and Budget. 
Table 25. Madagastar: Carrent Budgekary Expenditure, $1997-2001$

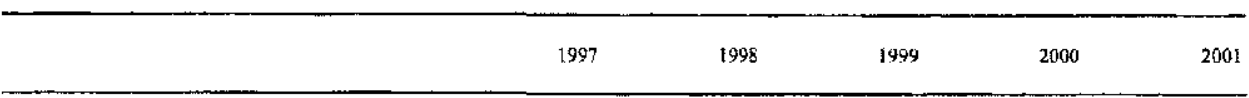

(in biltions of Malagasy francs)

Economic classification

\begin{tabular}{|c|c|c|c|c|c|}
\hline Current expenditure & $1,960.2$ & $2,146.1$ & $2,175,0$ & $2,402.6$ & 3.081 .7 \\
\hline Personiel & 669.6 & 826.4 & $1,000.6$ & $1,042.4$ & $1,337.6$ \\
\hline Other noninterest expenditure & 583.0 & 671.9 & 679.0 & 761.8 & $1,071.5$ \\
\hline Goods and services & 336.7 & 318.0 & 402.2 & 499.5 & 686.5 \\
\hline Transfers and subsidies & 246.3 & 353.9 & 276.8 & 262.3 & 385.0 \\
\hline Interest on pubïic deba & 548.9 & 553.8 & 492.8 & 612.3 & 591.9 \\
\hline Foreigrt interest obligations & 503.5 & 466.5 & 325.0 & 371.2 & 349.1 \\
\hline Domestic interest obligations & 45.4 & 87.7 & 167.8 & 241.1 & 242.8 \\
\hline Treasury operations: & $\$ 20.1$ & 94.0 & 2.6 & -56.5 & 54.3 \\
\hline Emergency expenditure ${ }^{2}$ & 38.5 & 0.0 & 0.0 & 40.6 & 25.0 \\
\hline Counterpart funds-fmanced operations & $\cdots$ & $\cdots$ & $\cdots$ & 2.0 & 1.4 \\
\hline \multicolumn{6}{|l|}{ unctional classification } \\
\hline Budgetary expenditure & $1,960.2$ & $2,146.1$ & 2.175 .0 & $2,402.6$ & $3,081.7$ \\
\hline General expenditure ${ }^{3}$ & 688.7 & 635.9 & 695.0 & 880.0 & $1,067.5$ \\
\hline Of which: defense & 267.4 & 274.5 & 282.8 & $3: 9.7$ & 428.4 \\
\hline Education & 258.5 & 289.0 & 392.0 & 555.5 & 736.6 \\
\hline Of which : iniversities & 67.2 & 75.2 & 80.1 & $91, A$ & 131.6 \\
\hline Health & 98.7 & 141.2 & 150.3 & 182.6 & 265.4 \\
\hline Social and community services & 19.3 & 27.7 & 34.1 & 46.3 & 48.0 \\
\hline Economic services & 122.1 & 120.7 & 143.2 & 160.9 & 163.2 \\
\hline \multicolumn{6}{|l|}{ Of which } \\
\hline Agriculture & 68.7 & 51.9 & 55.9 & 832 & 72.4 \\
\hline Pubilic works & 16.5 & 29.4 & 41.7 & 18.8 & 25.3 \\
\hline Other $^{5}$ & 772.9 & 931.6 & 760.4 & 577.3 & 801.0 \\
\hline
\end{tabular}

Memorandum items:

(In percent of GDP)

$\begin{array}{llllll}\text { Noninterest budgetary expenditure } & 6.9 & 7.4 & 7.2 & 6.9 & 7.9 \\ \text { Social sector current expenditure }{ }^{6} & 2.1 & 2.3 & 2.5 & 3.0 & 3.5 \\ \text { Of which : health } & 0.5 & 0.7 & 0.6 & 0.7 & 0.9 \\ \text { Defeńse } & 1.5 & 1.3 & 1.2 & 1.2 & 1.4\end{array}$

Sources: Ministry of Economy, Finance, and Budget; and Fund staff estimates.

'Beginning in 1999, treasury revenue is classified as a negative outlay in treasury expenditures, which from then on are reported on a net basis.

${ }^{2}$ For 2000 , the government budgetized FMG 69 billion to address exceptional developments related to the resurgence of a cholera epidemic and the devastating effects of recent cyclones.

${ }^{3}$ lucluding national defensc and security expenüitures.

4 Including livestock, fishing, water, and forestry.

5 Including revenue sharing with local governments and payments to international organizations.

6 Including expenditure on eduzation, health, and social and comununity services. 
Table 26. Madagascat : Central Government Capital Expenditure, 1997-2001 ${ }^{1}$

1998

1999

2000

2001

(In percent of total government capital expenditures)

General public services

Education

Health

Social and community services

Economic services

Agriculture ${ }^{2}$

Industry, energy, and mining

Transportation

Communication services

Public works ${ }^{3}$

Trade

Scientific researcb

Total

\section{Budgetary capital expenditure}

Domestically financed

Foreign loans

Extrabudgetary

On-lending 4

External grant

Autolinancing

Other

Total

(In percent of GDP)
25.0

6.4

5.5

1.7

61.4

24.9

5.6

1.2

0.1

26.7

1.4

1.4

100

(In billions of Malagasy francs, unless otherwise indicated)

$\begin{array}{rrrrr}489.5 & 815.2 & 794.5 & 940.9 & 1307.7 \\ 208.4 & 392.1 & 364.8 & 599.1 & 878.3 \\ 281.1 & 423.1 & 429.7 & 341.8 & 429.4 \\ 66.1 & 64.9 & 83.8 & 55.2 & 63.9 \\ 42.1 & 74.8 & 86.0 & 75.3 & 75.3 \\ 578.8 & 640.1 & 670.6 & 767.8 & 733.9 \\ 0.0 & 17.4 & 0.0 & 0.0 & 0.0 \\ 0.0 & 0.0 & 0.0 & 0.0 & 0.0\end{array}$

14.0

7.0

7.0

12.0

60.0

19.0

10.0

4.0

0.0

26.0

1.0

0.0

100

$1,612.4$

6.5
20.3

10.1

8.1

1.5

59.8

24.0

5.8

2.6

0.0

26.5

0.4

0.4

100
35.2

4.9

6.5

1.7

51.7

20.9

5.2

2.6

0.6

21.0

0.7

0.7

100
100

32.5

5.4

4.8

2.3

55.1

19.9

7.6

1.8

0.4

24.5

0.3

0.6

00 
Table 27. Madagaseat: Central Government Personnel Expenditure and Number of Civil Servants, 199\%-200!

(In thousands of Malagasy francs, unless otherwise indicaned)

\begin{tabular}{|c|c|c|c|c|c|}
\hline & 1997 & 1998 & 1999 & 2000 & 2001 \\
\hline Personnel expenditure (commitment basis) ${ }^{12}$ & 669.6 & 826.4 & $1,000.6$ & $1,042.4$ & $1,337.6$ \\
\hline Annual change in percent & 28.0 & 23.4 & 21.1 & 4.2 & 28.3 \\
\hline In percent of current budgetary expenditure & 34.2 & 38.5 & 46.0 & 43.4 & 43.4 \\
\hline In percent of wtal government expenditure & 21.3 & 23.6 & 26.4 & 25.0 & 25.4 \\
\hline ln percent of GDP & 3.7 & 4.1 & 4.3 & 4.0 & 4.4 \\
\hline \multicolumn{6}{|l|}{ Civil servants (number at end-December) ${ }^{3}$} \\
\hline Civilian & 93,971 & 103,831 & 113,728 & 109,603 & 111,372 \\
\hline Military & 21,760 & 21,760 & 21,760 & 21,760 & 21,491 \\
\hline Total & 115,731 & 125,591 & 135,488 & 131,363 & 132,863 \\
\hline Annual percent change & 0.7 & 8.5 & 7.9 & $\cdot 3.0$ & 1.1 \\
\hline \multicolumn{6}{|l|}{ Menorandum items: } \\
\hline \multicolumn{6}{|l|}{ Average monthly civil servants' salary } \\
\hline In thousand of Malagasy franes & 418.2 & 467.9 & 553.4 & 661.5 & 701.0 \\
\hline Annual change in percent & 11.6 & 11.9 & 18.3 & 19.5 & 6.0 \\
\hline Anmual percent change in real terms ${ }^{4}$ & 7.1 & 5.7 & 8.4 & 7.6 & -1.4 \\
\hline Total governinent expenditure (billions of Malagasy francs) & $3,137.1$ & $3,819.3$ & $3,790.9$ & $4,168.6$ & $5,262.6$ \\
\hline Nominal GDP (billions of Malagasy francs) & $18,051.0$ & $20,343.0$ & $23,379.1$ & $26,242,0$ & $30,333.8$ \\
\hline
\end{tabular}

Sources: Ministry of Econony, Finance, and Budget; and Fund staff' estimates.

'Including only regular stafC Expenditure on some categories of temporary personel is included in goods and services outlays.

${ }^{2}$ Exciuding medical expenses.

'Data on actual positions filled, which may differ from other sources.

4Annual average percentage change in the average civil servants' saiary detated by the consumer price index. 
Table 28. Madugascar: Structure and Adjustment of Pubỉe Sector Salaries, 1997-2002

(In thousando of Malagasy francs)

Jan. 1997 - Jan. 1998 - May 1998 - Mar. 1999 - Mar. 2000 - Feb. 2001 - Starting

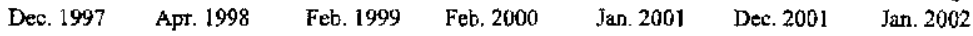

Category [

Minimum

Maximum

(midpoint)

Category' II

Minimum

Maximum

(midpoint)

242.8

273.5

365.7

319.6

287.0

239.3

317.5

278.4

.. $\quad 267.5$

.. 355.0

... 311.3

453.8

375.4

313.2

496.0

404.6

354.2

537.0

445.6

Category III

\section{Minimum \\ Maximum}

(zirdpoint)

Categories $\mathrm{IV}$ and $\mathrm{V}$

Minimum

Maximum

(midpoint)

308.4

559.5

434.0

341.4

613.0

477.2

357.6

399.8

583.1

1]$,

864.3

620.9

661.9

509.1

550.9

$1,254.9$

937.9

$1,295.9$

978.9

Categories VI and VII

Minimum

Maximum

(midpoint)

350.0

619.0

484.5

385.6

672.6

529.1

414.9

750.6

452.0

818.2

582.8

635.1

680.7

$1,448.5$

1,064

727.5

1,587.6

$1,157.6$

768.5

$1,628.6$

$1,198.6$

Categories VIII and LX

Minimum
Maximum
(midpoint)

399.4

734.9

438.4

800.6

619.5

491.3

535.6

926. I

708.7

1,044.?

823.3

$1,744.5$

882.3

$1,902.0$

923.5

789.9

$1,283.9$

$1,392.3$

$1,943.0$

$1,433.3$

Category X

Minimum

413.0

455.7

511.0

667.1

$1,565.0$

$1,699.4$

1740.4

Maxinum

898.9

975.3

$1,198.9$

$1,306.8$

$2,183.5$

2221.1

2262.1

(midpoint)

656.0

715.5 
Table 29. Madagaccar: Monetary Survey, 1997-2001

(In bithons of Malagasy francs: uniess otherwise indicaled; end of period)

\begin{tabular}{|c|c|c|c|c|c|}
\hline & 1997 & 1998 & 1999 & 2000 & 2001 \\
\hline Net foreign assets & $1,771 . !$ & $1,172.0$ & $1,711.5$ & $2,006.3$ & $2,571.1$ \\
\hline Central bank & $i, 105.3$ & 596.1 & $1,055.3$ & $1,170.5$ & $1,787.7$ \\
\hline Commercial banks & 665.8 & 5760 & 656.2 & 835.9 & 783.5 \\
\hline Long-term foreign Hibilities & -206.8 & $-2 \uparrow 1.2$ & -261.0 & -225.3 & -264.2 \\
\hline Central bask & -173.5 & -186.1 & -190.8 & -167.5 & -1490 \\
\hline Cornumexc:al banks & -33.3 & -25.1 & -702 & .61 .7 & -115.2 \\
\hline Net domestic assets & $2,28: .9$ & $2,208.2$ & $3,530.6$ & $4,139.8$ & $5,050.7$ \\
\hline Nis credit to govemment & 680.1 & $\$, 453.3$ & $1,715.0$ & $1,856.5$ & 2.477 .1 \\
\hline Net claims on government ${ }^{1}$ & 584.3 & $1,725,5$ & $1,560.7$ & $1,56 \overline{3} .3$ & $2,047,8$ \\
\hline Cenural bank & 387.7 & $3,031.1$ & $1,220.6$ & $1,162.7$ & $1,207.8$ \\
\hline Commerciaj banks & 196.6 & 294.4 & 340.0 & 400.6 & 840.0 \\
\hline Other claims & 95.8 & 127.8 & 1.54 .4 & 293.2 & 429.2 \\
\hline Credit to the econouny & $1,814.1$ & $1,828.2$ & $1,955.4$ & $2,415.0$ & $2,778.3$ \\
\hline Central bank & 15.1 & 15.9 & 15.8 & 112.2 & 276.4 \\
\hline Commercial banks & $1,757.6$ & $1,8: 1.8$ & $1,937.5$ & $2,303.3$ & $2,500.8$ \\
\hline Other claims & 1.4 & 0.5 & 2.3 & 0.5 & 1.2 \\
\hline Other items (net) & -212.3 & -73.2 & -139.9 & -131.8 & -204.7 \\
\hline For cign currency adjustment & 240.3 & 225.7 & 65.9 & 84.6 & 55.4 \\
\hline Central banix & 59.5 & 70.9 & y2.4 & 190.0 & 166.0 \\
\hline Commercial banks & -512.2 & 369.9 & .298 .2 & -406.4 & .426 .1 \\
\hline Broad money (M3) & $3,846.2$ & $4,169.1$ & $4,981.1$ & $5,9 i 6.8$ & $7,357.7$ \\
\hline Courrency in circulation & $1,025.6$ & $1_{2} 168.2$ & $1,434,9$ & $1,786.6$ & $2,159.6$ \\
\hline Tota deposits & $2,820.6$ & 3.000 .8 & $3,546.2$ & $4,130.2$ & $5,198.1$ \\
\hline Demand deposits & $1,658.6$ & 1,8012 & $2,145.9$ & $2,342.1$ & $3,266,1$ \\
\hline Quasi money & $1,161.9$ & $1,199.7$ & 1.400 .3 & {$[, 788.2$} & $\mathbf{j}, 932.0$ \\
\hline \multicolumn{6}{|l|}{ Of which } \\
\hline Resident deposits in foreign cutrencies & 441.9 & 474.7 & 614.5 & 841.4 & 773.9 \\
\hline Short-term obligations & 70.4 & 123.8 & $: 51.8$ & 169.3 & 172.7 \\
\hline \multicolumn{6}{|l|}{ Memorandium irems: } \\
\hline Net foreign assets & 18.6 & -15.6 & 12.9 & 5.9 & 9.5 \\
\hline Net dumestic assets & 1.9 & 24.1 & 7.7 & 12.2 & 15.4 \\
\hline Net credil to govamment & -3.3 & 20.1 & 6.3 & 2.8 & 10.5 \\
\hline Credit to the econumy & 6.7 & 0.4 & 3.1 & 9.2 & 6.1 \\
\hline Change from previous year (in percent) & 13.4 & 0.8 & 7.0 & 23.5 & 15.0 \\
\hline Broad money (As) & $\begin{array}{r}19.8 \\
:\end{array}$ & 8.4 & 19.5 & 18.8 & 24.4 \\
\hline
\end{tabular}

Suurces: Central kank of Madagascar; and Fund siaff estimates.

\footnotetext{
'In 2001, the change in net claims on government differs from the amount indicated in the govenument operations tables because the latter does not include the assumption by the government of the state petroleum companys' (SOLIMA) debt to the central bark, escimated at FMO 61.8 billion.
} 
Table 30. Madagascar: Summary Accounts of the Central Bank, 1997-2001

(In billions of Malagasy francs, unless otherwise indicated; end of period)

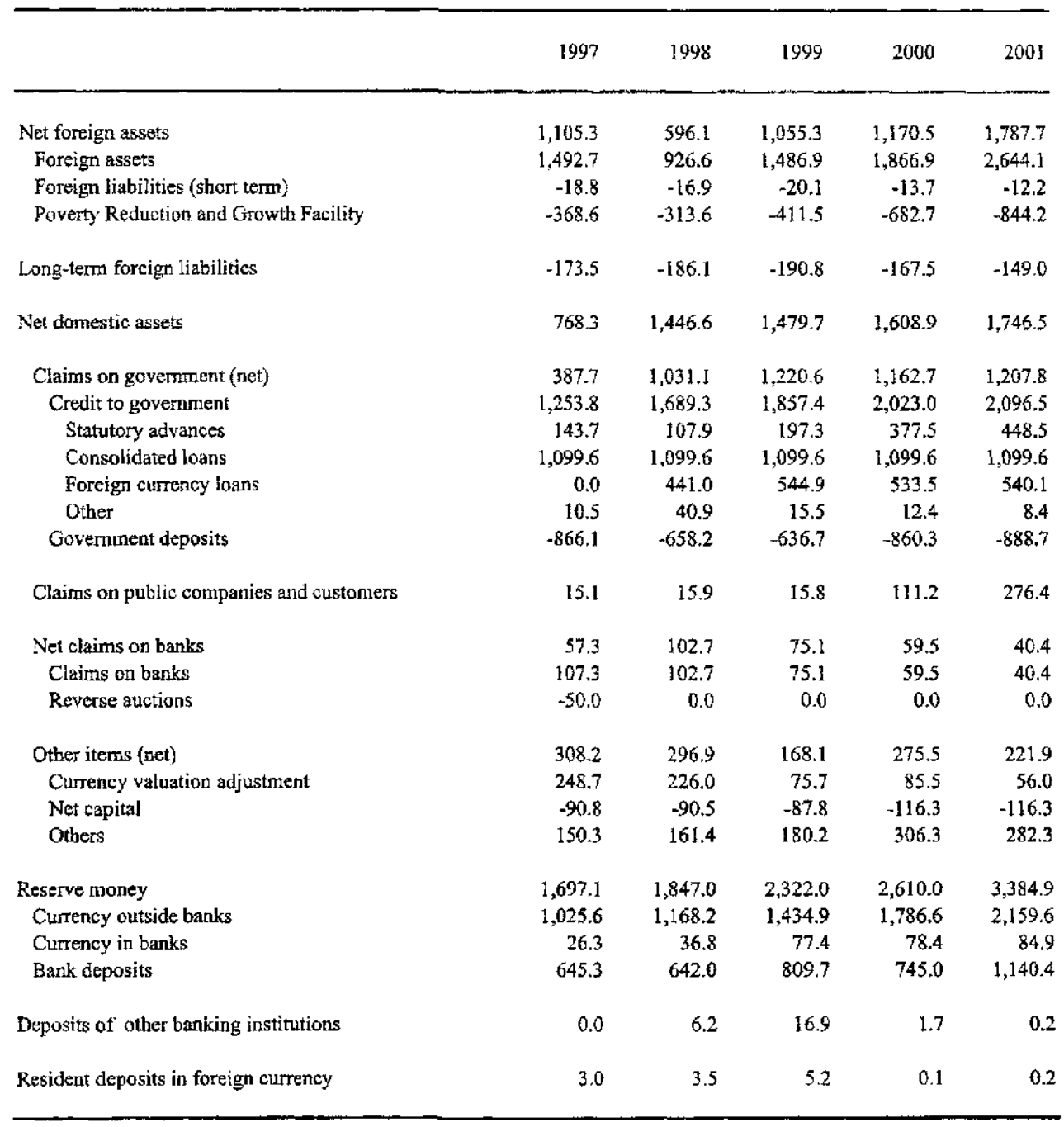

Sources: Central Bank of Madagascar, and Fund staff estimates. 
Table 31. Madagascar: Summary Accounts of Commercial Banks, 1997-2001

(In billions of Malagasy francs, unjess otherwise indicated; end of period)

\begin{tabular}{|c|c|c|c|c|c|}
\hline & 1997 & 1998 & 1999 & 2000 & 2001 \\
\hline Net bank liquidity & $1,246.8$ & $1,126.9$ & $1,398.0$ & $1,538.0$ & $1,853.1$ \\
\hline $\mathrm{Ne}^{\dagger}$ foreign assets & 665.8 & 576.0 & 656.2 & 835.9 & 783.5 \\
\hline Of which: nonresident nonbank deposits & 55.7 & 89.2 & 114.9 & 107.9 & 101.1 \\
\hline Long-term foreign liabilities & -33.3 & -25.1 & -70.2 & -61.7 & -115.2 \\
\hline Reserves & 671.5 & 678.8 & 887.1 & 823.4 & $1,225,3$ \\
\hline Currencies in banks & 26.3 & 36.8 & 77.4 & 78.4 & 84.9 \\
\hline Deposits at central bank & 645.3 & 642.0 & 809.7 & 745.0 & $1,140.4$ \\
\hline Net recourse to central bank & 57.3 & 102.7 & 75.1 & 59.5 & 40.4 \\
\hline Recourse to central bank & 107.3 & 102.7 & 75.1 & 59.5 & 40.4 \\
\hline Reverse auctions & -50.0 & 0.0 & 0.0 & 0.0 & 0.0 \\
\hline Net domestic assets & $1,473.7$ & $1,736,0$ & $1,969.6$ & $2,296.6$ & $2,914.2$ \\
\hline Claims on govermment (net) & 196.6 & 294.4 & 340.0 & 400.6 & 840.0 \\
\hline Credit to government & 356.5 & 436.4 & 481.0 & 606.5 & $1,182,4$ \\
\hline Govemment deposits & -159.9 & -142.0 & -140.9 & .205 .9 & -342.4 \\
\hline Of which : deposits of administrative agencies & -155.0 & -138.9 & -132.6 & -197.2 & -332.8 \\
\hline Claims on private sector & $1,797.6$ & $1,811.8$ & $1,937.5$ & $2,303.3$ & $2,500.8$ \\
\hline Of which: in foreign currency & $\cdots$ & 36.7 & 0.0 & 0.0 & 0.0 \\
\hline In millions of SDRs & $\ldots$ & 4.8 & 0.0 & 0.0 & 0.0 \\
\hline Net capital & -645.9 & -399.5 & -445.8 & -517.9 & -620.7 \\
\hline Other items (net) & 125.3 & 29.3 & 137.9 & $\$ 10.6$ & 194.1 \\
\hline Currency valuation adjustment & -8.4 & -0.3 & -9.7 & -0.9 & -0.5 \\
\hline Other & 133.7 & 29.6 & 147.6 & 111.5 & 194.6 \\
\hline Deposits & $2,650.1$ & $2,733.1$ & $3,215.8$ & $3,665.3$ & $4,594.5$ \\
\hline Demand deposits & $1,643.7$ & $1,783.1$ & $2,115.8$ & $2,228.9$ & $3,074.1$ \\
\hline Time deposits & 567.4 & 478.8 & 490.7 & 595.2 & 746.7 \\
\hline Foreign currency & 439.0 & 471.3 & 609.3 & 841.3 & 773.7 \\
\hline In millions of SDRs & $\cdots$ & 61.9 & 67.8 & 98.5 & 92.9 \\
\hline Short-term bonds & 70.4 & 129.8 & 151.8 & 169.3 & 172.7 \\
\hline
\end{tabular}

Sources: Central Bank of Madagascar; and Fund staff estimates. 
Tabie 32. Madagascar: Foreign Reserve Assets and Liabilities of the Central Bank, 1997.2001

(In miltions of SDRs, unless otherwise indicated; end of period)

\begin{tabular}{|c|c|c|c|c|c|c|c|c|c|c|c|c|c|c|}
\hline & \multirow{2}{*}{\multicolumn{2}{|c|}{$\frac{1997 \quad 1998}{\text { Decernber }}$}} & \multicolumn{4}{|c|}{1999} & \multicolumn{4}{|c|}{2000} & \multicolumn{4}{|c|}{2001} \\
\hline & & & Mar. & Jun. & Sep. & $\overline{\text { Dec. }}$ & Mar. & Jan. & Sep. & Dec. & Mar. & S1เ. & Sep. & Dec. \\
\hline Foreign assets & 208.4 & 121.8 & 134.4 & 124.5 & 140.5 & 165.5 & 175.5 & 148.9 & 212.5 & 218.7 & 243.9 & 264.2 & 263.8 & 317.5 \\
\hline Of which: time deposits & 6.6 & 67.4 & 30.6 & 110.5 & 120.1 & 121.7 & 148.4 & 92.2 & 156.0 & 129.4 & 147.2 & 149.7 & 206.1 & 258.9 \\
\hline Foreign liabilities & 54.1 & 43.4 & 41.3 & 38.6 & $\$ 1.0$ & $4 \overline{8} .0$ & 46.3 & 44.8 & 75.0 & 81.6 & 91.6 & 92,3 & 91.5 & 102,8 \\
\hline Nonsesident deposits & 2.4 & 1.9 & 1.3 & 2.5 & 1.9 & 2.1 & 1.6 & 1.3 & 1.6 & 1.4 & 1.5 & 1.9 & 0.8 & 0.9 \\
\hline Intemational organizations & 0.3 & 0.3 & 0.1 & 0.0 & 0.2 & 0.2 & 0.2 & 0.2 & 0.2 & 0.2 & 0.0 & 0.0 & 0.1 & 0.1 \\
\hline MMF & 51.5 & 41,2 & 39.9 & 36.1 & 48.9 & 45.8 & 44.5 & 43.2 & 73.2 & 80.0 & 90.0 & 90.0 & 90.0 & 101.4 \\
\hline External payments arrears & 0.0 & 0.0 & 0.0 & 0.0 & 0.0 & 0.0 & 0.0 & 0.0 & 0.0 & 0.0 & 0.0 & 0.0 & 0.0 & 0.0 \\
\hline Net forrign assets & 154.3 & 78.3 & 93.0 & 85.9 & 89.4 & 117.5 & 129.2 & 104.1 & 137.5 & 137.1 & 152.4 & 172.0 & 172.2 & 214.7 \\
\hline Excluding IMF and arrears & 205.8 & 119.6 & 133.0 & 122.0 & 138.3 & 163.3 & 173.8 & 147.4 & 210.7 & 217.1 & 242.4 & 262.0 & 262.2 & 316.0 \\
\hline \multirow{2}{*}{$\begin{array}{l}\text { Memorandum item: } \\
\text { Exchange rate: Malagasy francs } \\
\text { per SDR }\end{array}$} & & & & & & & & & & & & & & \\
\hline & $7,161.5$ & $7,608.2$ & $8,194,4$ & $9,003.1$ & $8,774.5$ & $8,984.5$ & $9,437,3$ & $8,779.0$ & $8,735.7$ & $8,537.8$ & $8,617.2$ & $8,430.7$ & $8,136.4$ & $8,327.5$ \\
\hline
\end{tabular}

Sourcc: Centrai Bark of Madagascar. 
Table 33. Madagascar: Structure of Market Interest Rates, 1997-2001 (in percent per aunum)

\begin{tabular}{|c|c|c|c|c|c|c|c|c|c|c|c|c|c|}
\hline & & \multicolumn{3}{|c|}{ Central Bank } & \multicolumn{4}{|c|}{ Money Markcl } & \multicolumn{5}{|c|}{ Treasury Bitls. } \\
\hline & & \multirow{2}{*}{$\begin{array}{l}\text { Base } \\
\text { ratc }\end{array}$} & ling & \multirow{3}{*}{$\begin{array}{l}\text { Overnight } \\
\text { lending }\end{array}$} & \multirow{3}{*}{$\begin{array}{l}\text { Lending } \\
\text { on bid }\end{array}$} & \multirow{2}{*}{$\begin{array}{l}\text { Deposits } \\
\text { on bid }\end{array}$} & \multirow{3}{*}{$\begin{array}{l}\text { lnter- } \\
\text { bank }\end{array}$} & \multirow{2}{*}{$\begin{array}{l}\text { Oppen } \\
\text { market }\end{array}$} & \multicolumn{4}{|c|}{ Pritanary market } & \multirow{3}{*}{$\begin{array}{l}\text { Secoudary } \\
\text { markel } \\
\text { (Weighteri } \\
\text { average) }\end{array}$} \\
\hline & & & days & & & & & & $\begin{array}{c}4 \\
\text { weeks }\end{array}$ & $\begin{array}{c}12 \\
\text { weeks }\end{array}$ & $\begin{array}{c}24 \\
\text { wecks }\end{array}$ & $\begin{array}{l}\text { Weighted } \\
\text { average }\end{array}$ & \\
\hline & & \multicolumn{2}{|c|}{ (Ender of peried) } & & & \multicolumn{6}{|c|}{ (Weighted period averagc) } & & \\
\hline 1997 & & $9 . A$ & 14.00 & 16.00 & $\ldots$ & 6.48 & 10.27 & $\ldots$ & 8.13 & 7.73 & $y .05$ & 8.34 & 6.40 \\
\hline 1908 & & 10.00 & 12.50 & 14.50 & $\ldots$ & 5.11 & 10.46 & 13,20 & 9.47 & 11.29 & $\{1.59$ & 11.13 & 8.99 \\
\hline 1999 & & 15.00 & 17.50 & 19.50 & $\ldots$ & $\ldots$ & 16.11 & 15.23 & 12.30 & 15.15 & 15,44 & 14.64 & 14.99 \\
\hline 2000 & & 12.00 & 14.50 & 16.50 & $\ldots$ & $\ldots$ & 16.61 & 16.51 & 12.82 & 15.27 & 15.40 & 14.56 & $\ldots$ \\
\hline 2001 & & 19.50 & 13.00 & 15.00 & $\cdots$ & ... & 9.90 & $\cdots$ & $7.3 t$ & 10.91 & 10.98 & 9.96 & $\ldots$ \\
\hline \multirow[t]{12}{*}{2001} & Jan. & 12.00 & 14.50 & 16.50 & $\ldots$ & $\ldots$ & 12.51 & $\ldots$ & 11.07 & $\$ 4.05$ & 14.48 & 13.42 & 13.10 \\
\hline & Feb. & 12,00 & 14.50 & 16.50 & $\ldots$ & $\ldots$ & 13.00 & $\ldots$ & 20.46 & 13.90 & 34.07 & 13.32 & 10.68 \\
\hline & Mar. & 12.00 & 14.50 & 16.50 & $\ldots$ & $\ldots$ & 12.00 & $\ldots$ & 9.78 & 13.35 & 13.44 & 12.30 & 101.14 \\
\hline & Apr. & 12.00 & 14,50 & 16.50 & $\ldots$ & $\ldots$ & ... & $\ldots$ & 9.12 & 12,68 & 12.96 & 12.20 & 9.26 \\
\hline & May & 12.00 & 14.50 & 16.50 & $\ldots$ & $\ldots$ & 12,00 & $\ldots$ & K.II & 12.17 & 12.52 & 11.62 & 8.89 \\
\hline & Јит. & 10.50 & 13.00 & 15.00 & $\ldots$ & $\ldots$ & $\ldots$ & $\ldots$ & 7.40 & 10.91 & 11.35 & 9.65 & 7.79 \\
\hline & Jail. & 101.50 & 1300 & 15.00 & $\ldots$ & $\ldots$ & 10.50 & $\ldots$ & 7.05 & 9.99 & 10.19 & 9,34 & 7.68 \\
\hline & Aug. & 10.50 & 13.00 & 15.00 & $\ldots$ & $\ldots$ & 10.50 & $\ldots$ & 6.50 & 9.49 & 9.70 & 8.45 & 8.39 \\
\hline & Sep. & 10.50 & 13.00 & 15.00 & $\ldots$ & $\ldots$ & 10.50 & $\ldots$ & 6.09 & 9.06 & 9.41 & 8,56 & 7.57 \\
\hline & Ost. & 16.501 & 13.00 & 15.40 & $\ldots$ & $\ldots$ & 10.05 & $\ldots$ & 5.86 & 8.93 & 9.20 & 8.26 & 8.12 \\
\hline & Nov. & 900 & 11.50 & 13.50 & $\ldots$ & $\ldots$ & 9.00 & $\ldots$ & 5.75 & 9.04 & 9.19 & 8.18 & 7.37 \\
\hline & Dec. & 9.00 & 11.50 & 13.50 & $\ldots$ & $\ldots$ & 9.00 & $\ldots$ & 5.47 & 8.99 & 9.11 & 8.05 & 5.31 \\
\hline \multirow[t]{10}{*}{2002} & Jan. & 9.00 & 11.50 & 13.50 & $\ldots$ & $\ldots$ & 9.00 & $\ldots$ & 5.50 & 8.89 & 9.64 & 8.19 & 7.38 \\
\hline & Feb. & 9.00 & 11.50 & 13.50 & $\ldots$ & $\ldots$ & $\ldots$ & $\ldots$ & $\ldots$ & $\ldots$ & $\ldots$ & $\ldots$ & 6.67 \\
\hline & Mar. & 9.00 & 11.50 & 13.50 & $\cdots$ & $\ldots$ & $\ldots$ & $\ldots$ & $\cdots$ & $\cdots$ & $\ldots$ & $\ldots$ & $\ldots$ \\
\hline & Apr. & 9.00 & 11.50 & 13.50 & $\ldots$ & $\ldots$ & $\ldots$ & $\ldots$ & $\ldots$ & $\ldots$ & $\ldots$ & $\ldots$ & 5.50 \\
\hline & May & 9.00 & 11.50 & 13.50 & $\ldots$ & $\ldots$ & $\ldots$ & 9.44 & $\ldots$ & $\ldots$ & $\ldots$ & $\ldots$ & 8.93 \\
\hline & Jun. & 9,00 & 11.50 & 13,50 & $\ldots$ & $\ldots$ & $\ldots$ & 8.44 & $\ldots$ & $\ldots$ & $\ldots$ & $\ldots$ & 8.44 \\
\hline & Jul. & 9.00 & 11.50 & $1,3.50$ & $\cdots$ & 9.00 & 9.00 & 9.50 & $\ldots$ & $\ldots$ & $\ldots$ & $\ldots$ & 9.47 \\
\hline & Alug. & 9.100 & 11.50 & 13.50 & $\ldots$ & 9.00 & 9.50 & 9.45 & $\ldots$ & $\ldots$ & $\cdots$ & $\ldots$ & 8.41 \\
\hline & Sep. & 9.09 & 11.56 & $1,3.50$ & $\ldots$ & $\ldots$ & $\ldots$ & $\ldots$ & $\ldots$ & $\ldots$ & $\ldots$ & $\ldots$ & $\ldots$ \\
\hline & Out. & 9.00 & 11.58 & 13.50 & $\ldots$ & $\ldots$ & $\ldots$ & $\ldots$ & 1100 & 11.90 & 12.70 & 12.09 & $\ldots$ \\
\hline
\end{tabular}

Source: Central Bantc of Madagascar.

CInternational Monetary Fund. Not for Redistribution 
Table 34. Madagascar: Structure of Commercial Bank Interest Rates, 1997-2001 (in percent per atnum)

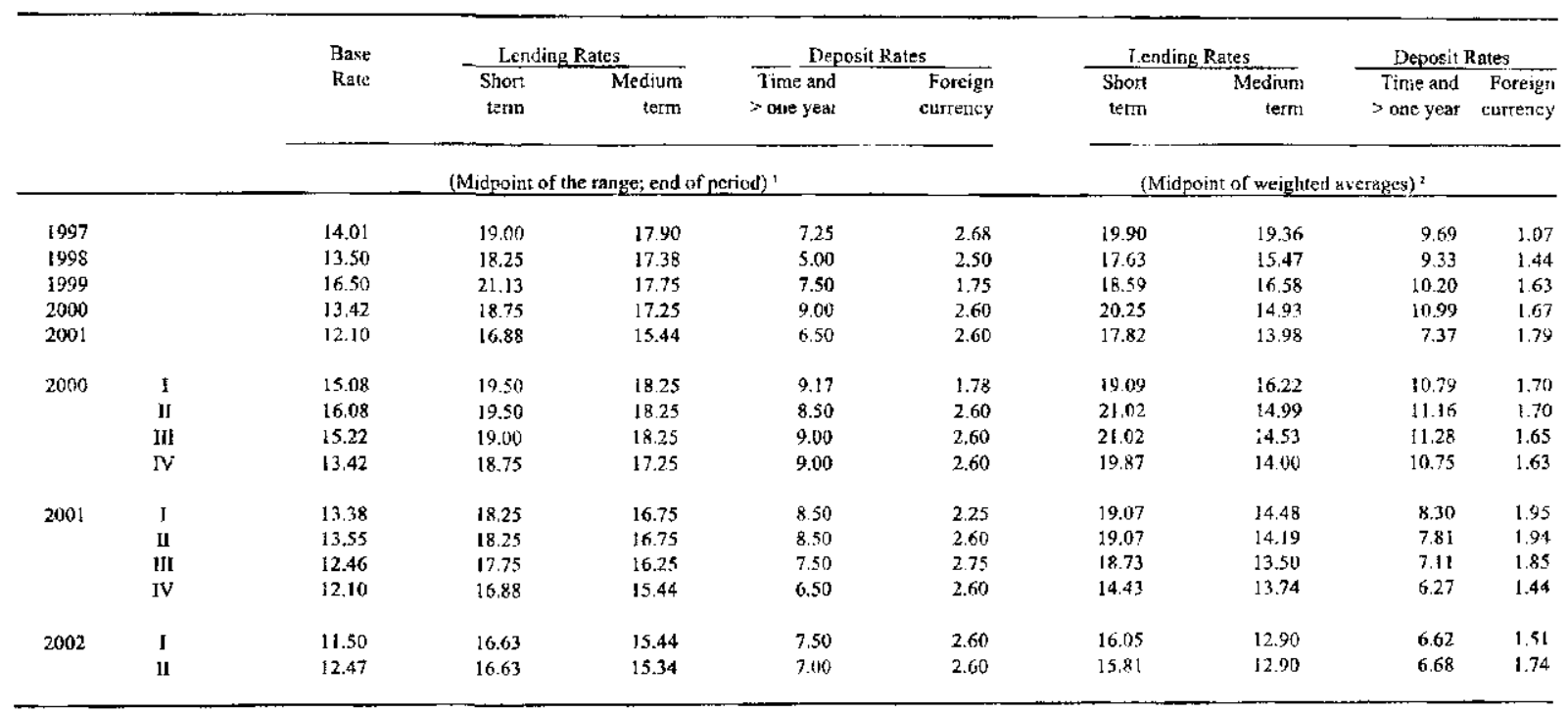

Source: Centrat Bank of Madagascar.

' On new business only; reported as a range by commercial banks.

${ }^{2}$ Calculated by the banks on their outstandings; the midpoint is a simple average of the highest and lowest rates reported by the banks. 
Table 35. Madagascar: Issues and Chustandings of Treasury Bilis, 1997-2001

(Nomiral values; in billions of Maliogasy fiances, urless atherwise indicated)

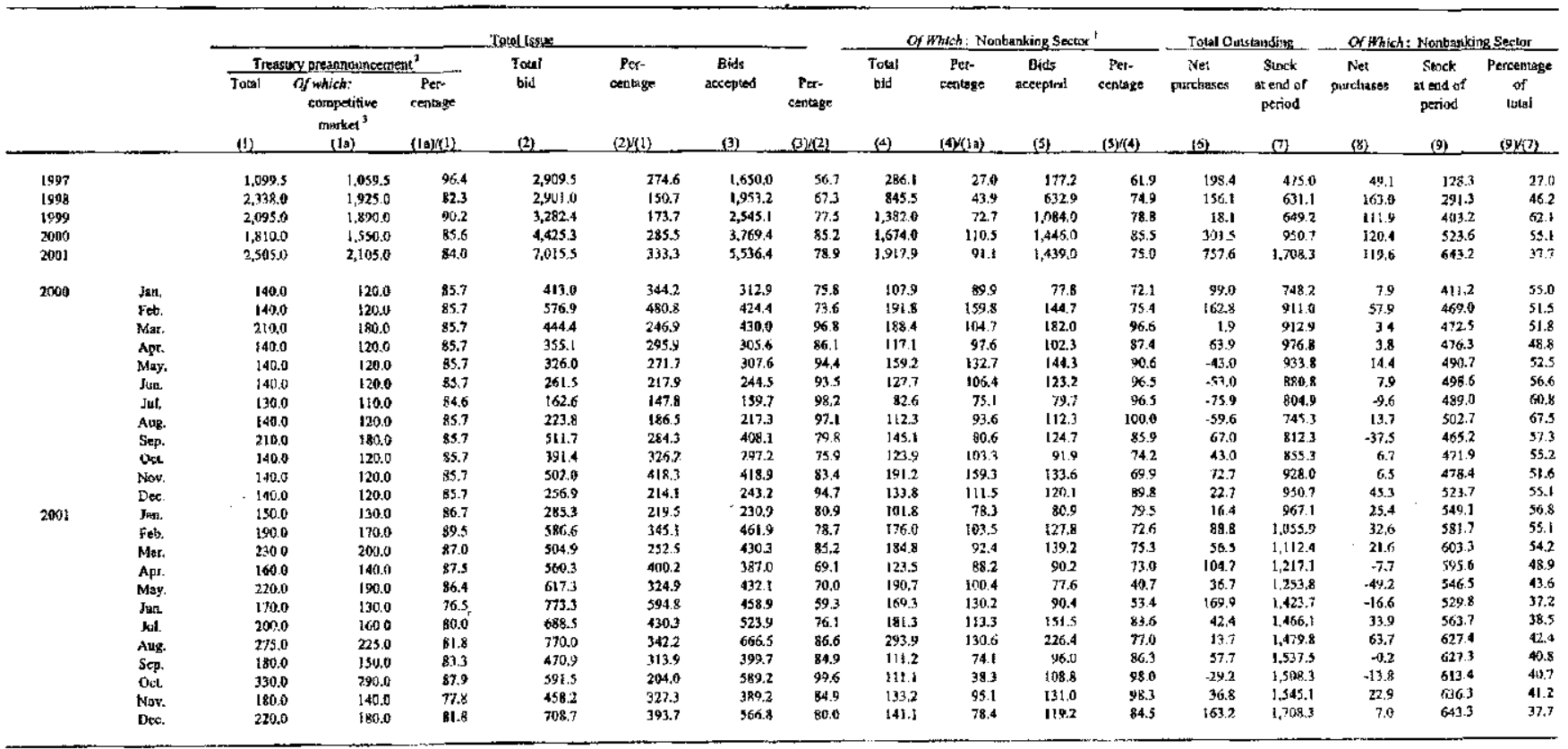

Source: Ceniral Hank of Madagascar.

Competitive martet only, since May i6, 1997.

${ }^{2}$ Since May 16, 1997 only.

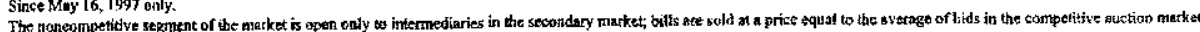




\begin{tabular}{|c|c|c|c|c|c|c|c|c|c|c|c|c|}
\hline & \multicolumn{2}{|c|}{ Number of Branches } & \multicolumn{2}{|c|}{ Sumber of Membenst } & \multicolumn{2}{|c|}{$\begin{array}{c}\text { Own Capitat and } \\
\text { Long-Term Resnutces } \\
\text { (millions of Malagsy frats) }\end{array}$} & \multicolumn{2}{|c|}{$\begin{array}{c}\text { Deposits } \\
\text { (midilions of Malaggy frences) }\end{array}$} & \multicolumn{2}{|c|}{$\begin{array}{l}\text { Logcrs Outstanding } \\
\text { (millions of Malaesy fiancs) }\end{array}$} & \multicolumn{2}{|c|}{ 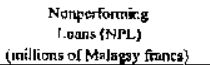 } \\
\hline & 123100 & $\frac{1231 / 01}{1231}$ & $12 / 31+\infty 0$ & $12 / 31 / 01$ & $-1231 \% 00$ & $\frac{12 \pi|1 / n|}{|2 / 3|}$ & $\frac{1}{12 \pi 1000}$ & $\frac{1260}{12 / 3101}$ & $12 / 36 / 000$ & $12 / 3101$ & $12 / 31 \times(k)$ & $\frac{12 t s 1 / 61}{12}$ \\
\hline \multicolumn{13}{|l|}{ 'ECAM ${ }^{\prime}$} \\
\hline VAKINANKARATRA & 46,0 & 45.0 & 8.359 .0 & $16,248.0$ & $2,567.9$ & 4.251 .4 & $1,263.3$ & $2,841.8$ & 2.861 .3 & $4,147.7$ & 13.9 & 125.0 \\
\hline AMORON'T MANIA & 22,0 & 21.0 & $3,576.0$ & $4,686,0$ & $1,408.0$ & $2,273.2$ & 277.0 & 402.0 & $1,956.6$ & 2312.0 & $n .3$ & 21.5 \\
\hline BONGOLAVA & 15.0 & 14.0 & $5,477,0$ & $5,3+3.0$ & $3,842,0$ & $3,921.8$ & 648.8 & 414.4 & 2.718 .1 & $2,063.5$ & 357.4 & $20 \leq 5$ \\
\hline ITASY & 22.0 & 22.0 & $5,153.0$ & 581 & $1,824,4$ & $2,554.1$ & $9 \$ 4.5$ & 745.6 & 2.734 .4 & 2.570 .6 & 202.8 & 57.3 \\
\hline VON IME RINA & 25.0 & 27.0 & $4,628,0$ & $5, \mathrm{RE} 3,0$ & 3801.8 & $3,589.8$ & 481.9 & 581.1 & 3.560 .5 & $2,034.2$ & 534.2 & $450, \pi$ \\
\hline SOFIA & 25.0 & 29.0 & $5,990.0$ & $7,660.0$ & 1898.3 & $3,013,4$ & 159.9 & 298.1 & $5,52.6 .5$ & $2,385.5$ & 22.5 & 164.3 \\
\hline Total CECAM & 155.0 & 158.0 & $33,183,0$ & $40,532,0$ & $15,342,4$ & $19,603.7$ & $3,7 k 2,4$ & $5,283.0$ & $14,957.4$ & $15,717.9$ & $1,206.1$ & $1,027,4$ \\
\hline $\begin{array}{l}\text { Qredititeposits (in pelcent) } \\
\text { NPL/crans (in percert) }\end{array}$ & .. & $\ldots$ & $\ldots$ & $\ldots$ & ... & ... & $\ldots$ & $\ldots$ & 395.5 & 297.4 & $\therefore .1$ & 6.5 \\
\hline \multicolumn{13}{|l|}{ mavo' } \\
\hline Total tlavo & 240.0 & 27,0 & $4,819.0$ & $6,223.0$ & 370.9 & $2,807.1$ & 1.271 .5 & $1,804,9$ & $1,063.8$ & 8818 & 128,0 & 47.0 \\
\hline Credily/deposits (kn percent) & $\ldots$ & $\ldots$ & $\ldots$ & $\ldots$ & $\ldots$ & $\ldots$ & $\ldots$ & $\ldots$ & 83.7 & 48.9 & $\ldots$ & ... \\
\hline NPLAsans (in percent) & & & & & & & & & & & 23.6 & 30.0 \\
\hline \multicolumn{13}{|l|}{ orv' } \\
\hline ANTANANARTVO & $12 . n$ & 16.0 & $9,891.0$ & $14,886.0$ & 462.8 & 741.9 & $3,753.6$ & $5,370.4$ & $1,815.2$ & $1,213.7$ & 746.7 & 442.4 \\
\hline TOAMASIMA & 38.0 & 39.0 & $17,979.0$ & $25,264,0$ & $2,187.4$ & 5,1789 & $10,548.7$ & $19,617.1$ & $6,76 . .9$ & $9,732.0$ & $1,175.4$ & $1,470.6$ \\
\hline AMEBATONDKAZAXA & 12.0 & 12.0 & $9,086.0$ & 10,1920 & $1,316.6$ & 1.640 .3 & $4,563.5$ & 5.180 .1 & $4,011.2$ & $3,106.5$ & 1.476 .5 & $2,397.8$ \\
\hline SAVA & 18,0 & 18.t) & $8,510,0$ & $11,285.0$ & $1,207.7$ & $1,928.7$ & $9,289.5$ & 17.209 .2 & $2,2,43,2$ & $1,944,0$ & 141.3 & 500.0 \\
\hline Total OTR & 80,0 & 85.0 & $45,466.0$ & $61,627.0$ & 6.174 .5 & $9,490,0$ & $28,155.3$ & $47,376,8$ & $14,838,6$ & $15,996.2$ & $3,499.4$ & $4,800.1$ \\
\hline Ceeditisfleposits (in percent) & ... & $\ldots$ & $\ldots$ & $\ldots$ & $\ldots$ & $\ldots$ & ... & $\ldots$ & 52.7 & 33.8 & $\ldots$ & $\ldots$ \\
\hline NPLiloons (in pricenit) & & & & & & & & & & & 23.6 & 30.0 \\
\hline \multicolumn{13}{|l|}{$A B C A^{\prime}$} \\
\hline TAFITA & 45.0 & 27.0 & $2,011.0$ & $1,925.0$ & 871.6 & 674.1 & 70,4 & 95.6 & 338.3 & 566.1 & 109 & 565.9 \\
\hline Avorke & & 18.0 & $1,114.0$ & $1,073.0$ & $5 \leqslant 0.4$ & 418.5 & 51.7 & 29.4 & 250.5 & 430.4 & 3R.9. & 429.8 \\
\hline TSARAJ ORG & 9.0 & 9.0 & $1,419.0$ & $1,570.0$ & & $10 \leqslant 3$ & & 88.2 & 691.8 & 302.2 & & \\
\hline Total AECA & 54.0 & 54.0 & $4,544,0$ & $4.56 B .0$ & $1,382.0$ & $1,197.9$ & 122.1 & 213.2 & $1,270.6$ & 1.298 .7 & 49.8 & 995.7 \\
\hline Crodilsideposiss (in pereent) & $\ldots$ & $\ldots$ & ... & $\ldots$ & ... & $\ldots$ & $\ldots$ & $\ldots$ & $1,040.6$ & 509.2 & $\ldots$ & ... \\
\hline NPUleans (in persil) & & & & & & & & & & & 3.9 & 76,7 \\
\hline \multicolumn{13}{|l|}{ ADEP' ${ }^{\prime}$} \\
\hline Total ADEFI & 23.0 & 29,0 & $3,942.0$ & $4,027.0$ & $11,377.4$ & 11.944 .2 & 677.5 & $1.071,3$ & $10,936.9$ & $12,412.1$ & 61,3 & 109.3 \\
\hline Cenditsideposits (in percent) & $\ldots$ & $\cdots$ & $\ldots$ & ... & ".. & $\ldots$ & $\ldots$ & $\ldots$ & $1,614.3$ & $1,158,4$ & $\cdots$ & $\ldots$ \\
\hline NeLloenz (in perceent) & & & & & & & & & & & 0.6 & 0.9 \\
\hline Grand Lotal & 336.0 & 353.0 & 91,954.j) & $\{16,977,0$ & $34,447.2$ & $45,042.9$ & 34,0088 & $55,749,4$ & $43,066.8$ & $45,301.7$ & $4,941.6$ & $6,979.5$ \\
\hline [Yedit/deposiss (11 perrent) & $\therefore$ & $\ldots$ & $\ldots$ & $\ldots$ & - & $\cdots$ & ... & $\ldots$ & 126.6 & $\times 3.1$ & $\ldots$ & 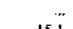 \\
\hline NPLLomes (in percent) & & & & & & & & & & & 11.5 & 15.1 \\
\hline
\end{tabular}

Source: Madagascar Banking and Finarrial Supervisinot Commission,

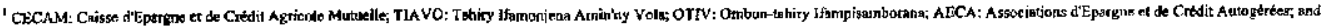
ADEF1: Aclíns pour le Dévitoppemenl et le Financentens des Mieco-tiotecprises. 
Table 37. Madagascar: Summary Balance of Payments, 1997-2001

(In millions of SDRs, unless otherwise indicated)

\begin{tabular}{|c|c|c|c|c|c|}
\hline & 1997 & 1998 & 1999 & 2000 & 2001 \\
\hline Current account & -142.7 & $-205,0$ & -147.2 & -164.6 & -46.4 \\
\hline Goods and services & -208.2 & -213.8 & -210.7 & -214.8 & -114.3 \\
\hline Trade balance & -127.1 & +110.5 & -115.9 & $.78 .6 \mathrm{i}$ & 11.6 \\
\hline Exports & 368.5 & 385.0 & 427.1 & 628.5 & 757.9 \\
\hline Imports & -495.6 & -495.5 & .543 .0 & -707.1 & .746 .3 \\
\hline Net services & -81.1 & -103.3 & -94.8 & -136.2 & -125.9 \\
\hline Services, receipts & 194.1 & 208.1 & 238.5 & 270.9 & 276.3 \\
\hline Services, payments & -275.2 & -311.4 & -333.3 & .407 .1 & -402.2 \\
\hline Income & -66.6 & -54.2 & -31.1 & -52.5 & -46.7 \\
\hline Receipts & 14.2 & 18.0 & 15.1 & 16.6 & 18.7 \\
\hline Payments & -80.8 & -72.2 & -46.2 & -69.1 & -65.4 \\
\hline Of which: dividends & -5.0 & -5.0 & -6.4 & -20.0 & -30.0 \\
\hline interest & -75.8 & -67.2 & -39.8 & -40.1 & -44.4 \\
\hline Of which: government interest & -71.7 & -63.2 & -38.0 & -38.8 & -41.4 \\
\hline Clsrent transfers & 132.1 & 63.0 & 94.6 & 702.6 & 114.6 \\
\hline Government & 57.8 & 12.6 & 25.8 & 25.5 & 24.9 \\
\hline Budget aid & 45.7 & 8.1 & 20.8 & 16.5 & 36.7 \\
\hline Other (net) & 12.1 & 4.5 & 5,0 & 9.0 & -11.8 \\
\hline Private & 74.3 & 50.4 & 68.8 & 77.1 & 89.7 \\
\hline Capital and financial account & 162.3 & 78.3 & $13 \% .3$ & 82.3 & 67.6 \\
\hline Capital transiers & 77.6 & 73.5 & 94.2 & 87.0 & 88.6 \\
\hline Government & 82.4 & 73.5 & 94.2 & 87.0 & 88.6 \\
\hline Project grants & 82.4 & 73.5 & 94.2 & 87.0 & 88.6 \\
\hline Other & 0.0 & 0.0 & 0.0 & 0.0 & 0.0 \\
\hline Private sector & -4.8 & 0.0 & 0.0 & 0.0 & 0.0 \\
\hline Financial account & 64.1 & 24.4 & 41.8 & 36.6 & 91.1 \\
\hline Direct investment & 10.0 & 11.9 & 42.7 & 52.9 & 73.1 \\
\hline Of which: privatization receipts & 0.0 & 0.7 & 15.4 & 5.3 & 10.9 \\
\hline Portfolio investments & 0.0 & 0.0 & 0.0 & 0.0 & 0.0 \\
\hline Other & 54.1 & 12.5 & -0.9 & -16.3 & 18.0 \\
\hline Government & 78.1 & 0.5 & -2.1 & 8.7 & 21.5 \\
\hline Drawings & 155.5 & 90.2 & 75.0 & 86.9 & 90.2 \\
\hline Of which: project drawings & 54.0 & 64.0 & 56.5 & 46.2 & 60.4 \\
\hline budgetary support & 98.3 & 19.3 & 11.6 & 39.3 & 26.8 \\
\hline Amortization & -77.4 & -89.7 & -77.1 & -78.2 & -68.7 \\
\hline Private sector (net) & -5.4 & -5.3 & -1.3 & 0.0 & -7.3 \\
\hline Banks (net) & -18.6 & 17.3 & 2.4 & -25.0 & 3.8 \\
\hline Other (including errors and omissions) ${ }^{3}$ & 20.7 & -19.6 & 1.3 & -41.3 & -112.2 \\
\hline Of which: indemnification & 0.0 & -2.5 & -4.5 & -4.9 & -3.3 \\
\hline Overall balance & 19.7 & -126.6 & -9.9 & .82 .3 & 21.1 \\
\hline
\end{tabular}


Table 37. Madagascar: Summary Balance of Payments, 1997-2001 (concluded) (In millions of SDRs, unless otherwise indicated).

\begin{tabular}{|c|c|c|c|c|c|}
\hline & 1997 & 1998 & 1999 & 2000 & 2001 \\
\hline Financing & -19.7 & 126.6 & 9.9 & 82.3 & -21.1 \\
\hline Net foreign assets (increase -) & -39.5 & 76.6 & -34.0 & 28.4 & -76.9 \\
\hline Use of Fund credit (tret) & 0.7 & -10.3 & 9.7 & 34.8 & 21.4 \\
\hline Purchase & 13.6 & 0.0 & 13.6 & 38.6 & 22.7 \\
\hline Repurchases & -129 & -10.3 & -3.8 & -3.8 & $-1,3$ \\
\hline Other assets (net, increase -) & -40.2 & 86.9 & -43.7 & -6.3 & -98.3 \\
\hline Net change in arrcars (excluding the central bank) & -783.2 & 12.0 & 3.1 & -5.7 & 0.0 \\
\hline Atrears accumulation & 47.4 & 18.1 & 3.1 & 0.0 & 0.0 \\
\hline Repayment of arrears & -72.1 & -6.1 & 0.0 & -5.7 & -8.1 \\
\hline Rescheduling of arrears & .758 .5 & 0.0 & 0.0 & 0.0 & 8.1 \\
\hline Debt relief and cancelfation & 803.0 & 38.0 & 40.8 & 59.6 & 55.8 \\
\hline Cutrent maturities & 44.5 & 38.0 & 40.8 & 59.6 & 55.8 \\
\hline Arsears & 758.5 & 0.0 & 0.0 & 0.0 & 0.0 \\
\hline Residual financing gap & 0.0 & 0.0 & 0.0 & 0.0 & 0.0 \\
\hline Of which: Paris Club & 0.0 & 0.0 & 0.0 & 0.0 & 0.0 \\
\hline \multicolumn{6}{|l|}{ Memorandum ttems: } \\
\hline \multicolumn{6}{|l|}{ External current account / GDP (in percent) } \\
\hline Excluding net official transfers & .7 .8 & -7.9 & -6.4 & -6.5 & .2 .0 \\
\hline Including net official transfers & -5.5 & -7.4 & .5 .4 & -5.6 & -1.3 \\
\hline Scheduled debt service ${ }^{3}$ (before debt relief) & 27.2 & 26.4 & 17.6 & 13.2 & 10.9 \\
\hline Scheduled debt service ${ }^{3}$ (after debt relief) & 19.3 & 20.0 & 11.4 & 6.5 & 3.7 \\
\hline Public sector scheduled debt service ${ }^{4}$ (before relief) & 58.0 & 52.1 & 34.9 & 31.3 & 25.4 \\
\hline \multicolumn{6}{|l|}{ Annual percentage changes } \\
\hline Export volume & -1.6 & 9.5 & 17.2 & 26.3 & 9.5 \\
\hline Import volume & 13.7 & 7.3 & 8.7 & 19.3 & 6.6 \\
\hline Real GDP & 3.7 & 3.9 & 4.7 & 4.8 & 6.0 \\
\hline Gross official reserves & 208.4 & 121.8 & 165.5 & 218.7 & 317.5 \\
\hline (weeks of goods and nonfactor services imports) & 14.1 & 7.8 & 9.8 & 10.2 & 14.4 \\
\hline (excluding privatization receipts) & 21.9 & $\$ 2.7$ & 14.4 & 15.7 & 21.4 \\
\hline
\end{tabular}

Sources: Central Bank of Mađagascar; and Fund staff estimates.

'Other official grants less payments due to scholarships and contributions to international organizations.

${ }^{2}$ Includes commercial credits received or granted.

${ }^{3}$ In percent of exports of goods and nonfactor services, before rescheduling.

${ }^{4}$ In percent of government revenue, before rescheduling. 
Table 38. Madagasear: Composition of Exports, f.o.b., 1997-2001

(Unless otherwise indicated, values in millions of SDRs, volumes in thousands of tons, and unit values in SDRs per kilogram)

\begin{tabular}{|c|c|c|c|c|c|}
\hline & 1997 & 1998 & 1999 & 2000 & 2001 \\
\hline \multicolumn{6}{|l|}{ Coffee } \\
\hline Value & 23.9 & 29.4 & 21.9 & 6.2 & 2.5 \\
\hline Volume & 25.9 & 30.0 & 27.9 & 13.0 & 6.2 \\
\hline Unit price & 0.9 & 1.0 & 0.8 & 0.5 & 0.4 \\
\hline \multicolumn{6}{|l|}{ Vanilla } \\
\hline Value & 6.9 & 11.8 & 20.2 & 44.2 & 128.8 \\
\hline Volume & 0.7 & 0.7 & 1.3 & 1.1 & 1.6 \\
\hline Unit price & 10.7 & 17.3 & 15.2 & 39.8 & 78.5 \\
\hline \multicolumn{6}{|l|}{ Cloves } \\
\hline Value & 8.9 & 6.9 & 12.0 & 34.5 & 75.4 \\
\hline Volume & 15.8 & 9.9 & 7.8 & 14.9 & 20.2 \\
\hline Unit price & 0.6 & 0.7 & 1.5 & 2.3 & 3.7 \\
\hline \multicolumn{6}{|l|}{ Pepper } \\
\hline Value & 2.1 & 0.9 & 1.7 & 1.1 & 1.1 \\
\hline Volume & 0.9 & 0.4 & 0.6 & 0.6 & 0.7 \\
\hline Unit price & 2.3 & 2.5 & 2.8 & 1.8 & 1.5 \\
\hline \multicolumn{6}{|l|}{ Shellfish } \\
\hline Value & 46.8 & 50.9 & 57.8 & 60.8 & 72.7 \\
\hline Volume & 8.0 & 8.5 & 12.2 & 11.5 & 12.0 \\
\hline Unit price & 5.8 & 6.0 & 4.7 & 5.3 & 6.1 \\
\hline \multicolumn{6}{|l|}{ Sugar } \\
\hline Value & 8.2 & 5.0 & 9.0 & 4.4 & 5.4 \\
\hline Volume & 20.6 & 11.6 & 31.2 & 14.0 & 21.0 \\
\hline Unit price & 0.4 & 0.4 & 0.3 & 0.3 & 0.3 \\
\hline \multicolumn{6}{|l|}{ Meat } \\
\hline Value & 0.9 & 0.1 & 0.01 & 0.1 & 0.0 \\
\hline Volume & 0.6 & 0.0 & 0.0 & 0.1 & 0.0 \\
\hline Unit price & 1.4 & 1.0 & 1.1 & 0.8 & 2.1 \\
\hline \multicolumn{6}{|l|}{ Cocoa } \\
\hline Value & 0.6 & 1.0 & 0.9 & 2.0 & 2.5 \\
\hline Volume & 0.7 & 0.9 & 1.0 & 2.3 & 3.2 \\
\hline Unit price & 0.9 & 1.1 & 0.9 & 0.9 & 0.9 \\
\hline \multicolumn{6}{|l|}{ Cotton cloth } \\
\hline Value & 12.3 & 28.1 & 21.5 & 27.6 & 17.5 \\
\hline Volume & 2.5 & 6.5 & 4.4 & 4.4 & 6.0 \\
\hline Unit price & 5.0 & 4.3 & 4.9 & 6.3 & 2.9 \\
\hline \multicolumn{6}{|l|}{ Sisal } \\
\hline Value & 1.4 & 1.2 & 1.5 & 1.5 & 2.7 \\
\hline Volume & 3.8 & 2.7 & 4.6 & 5.3 & 11.2 \\
\hline Unit price & 0.4 & 0.4 & 0.3 & 0.3 & 0.2 \\
\hline
\end{tabular}


Table 38. Madagascar. Composition of Exports, fo.b., 1997-2000 (concluded)

(Unless otherwise indicated, values in millions of SDRs, volumes in thousandis of tous, and unit values in SDRs per kilograni)

\begin{tabular}{|c|c|c|c|c|c|}
\hline & 1997 & 1998 & 1999 & 2000 & 2001 \\
\hline \multicolumn{6}{|l|}{ Petroleum products } \\
\hline Value & 10.6 & 8.0 & 9.8 & 17.2 & 20.0 \\
\hline Volume & 162.9 & 159.9 & 152.3 & 163.2 & 103.4 \\
\hline Unit price & 0.1 & 0.1 & 0.1 & 0.1 & 0.2 \\
\hline \multicolumn{6}{|l|}{ Chromite } \\
\hline Value & 6.5 & 5.8 & 3.3 & 4.2 & 5.1 \\
\hline Volume & 117.8 & 115.2 & 96.2 & 91.8 & 125.0 \\
\hline Unit price & 0.1 & 0.1 & 0.0 & 0.0 & 0.0 \\
\hline \multicolumn{6}{|l|}{ Graphite } \\
\hline Value & 5.0 & 5.0 & 3.2 & 4.4 & 3.1 \\
\hline Volume & 14.0 & 13.1 & 9.2 & 13.7 & 9.6 \\
\hline Unit price & 0.4 & 0.4 & 0.4 & 0.3 & 0.3 \\
\hline \multicolumn{6}{|l|}{ Essence of cloves } \\
\hline Value & 3.8 & 2.8 & 3.1 & 4.2 & 9.2 \\
\hline Volume & 1.4 & 1.0 & 1.2 & 1.3 & 1.1 \\
\hline Unit price & 2.7 & 2.7 & 2.7 & 3.3 & 8.2 \\
\hline \multicolumn{6}{|c|}{ Other items (including reexports) } \\
\hline Value & 94.9 & 84.9 & 97.2 & $168 . \hat{3}$ & 144.7 \\
\hline Volune & 0.8 & 0.8 & 0.9 & 1.5 & 1.3 \\
\hline Unit price & 116.0 & 104.6 & 102.4 & 110.8 & 108.2 \\
\hline \multicolumn{6}{|l|}{$\begin{array}{l}\text { Exports of the export } \\
\text { processing zone (EPZ) }\end{array}$} \\
\hline Value & 135.8 & 143.4 & 163.8 & 248.1 & 267.2 \\
\hline Volune & 1.2 & 1.4 & 1.6 & 2.2 & 2.5 \\
\hline Unit price & 116.0 & 104.6 & 102.4 & 110.8 & 108.2 \\
\hline Total value & 368.5 & 385.0 & 427.1 & 628.5 & 757.9 \\
\hline (percentage change) & 2.2 & 4.5 & 20.9 & 47.2 & 20.6 \\
\hline \multicolumn{6}{|l|}{ Memorandum iterns: } \\
\hline Traditional exports ${ }^{1}$ & 41.8 & 51.9 & 48.9 & 55.9 & 207.8 \\
\hline In percent of total & 11.4 & 13.6 & 11.5 & 8.9 & 27.4 \\
\hline Nontraditional exports ${ }^{2}$ & 324.9 & 330.7 & 377.0 & 572.7 & $5 \$ 0.1$ \\
\hline In percent of total & 88.6 & 86.4 & 88.5 & 91.1 & 72.6 \\
\hline Manufachured exports ${ }^{3}$ & 251.8 & 262.0 & 291.1 & 461.1 & 449.3 \\
\hline In percent of total & 68.7 & 68.5 & 68.4 & 73.4 & 59.3 \\
\hline
\end{tabular}

Sources: Central Bank of Madagascar; and Fund staff estimates.

${ }^{1}$ Value; comprises coffee, vanilla, cloves, and pepper.

${ }^{2}$ Value; comprises cotton cloth, petroleum, other items, and EPZ exports.

${ }^{3}$ Value; comprises EPZ exports, cottun cloth, petrol, and other items. 
Table 39. Madagascar: Composition of Imports, c.i.f., 1997-2001

\begin{tabular}{|c|c|c|c|c|c|}
\hline & 1997 & 1998 & 1999 & 2000 & 2001 \\
\hline & \multicolumn{5}{|c|}{ (m millions of SDRs) } \\
\hline Food & 35.3 & 39.9 & 33.5 & 58.4 & 65.7 \\
\hline Rice & 12.3 & 12.8 & 9.5 & 30.7 & 36.8 \\
\hline Other & 23.0 & 27.1 & 24.0 & 27.7 & 29.0 \\
\hline Energy (petroleum) & 84.9 & 74.8 & 90.2 & 160.4 & 131.8 \\
\hline Equipment goods & 106.3 & 109.6 & 117.1 & 126.6 & 128.7 \\
\hline Raw materials and spare parts & 100.0 & 91.2 & 97.6 & 123.1 & 103.1 \\
\hline Consumer goods & 88.3 & 108.1 & 112.8 & 85.4 & 103.9 \\
\hline Other imports (including EPZ) ${ }^{1}$ & 168.3 & 159.3 & 198.9 & 278.1 & 344.8 \\
\hline Total imports, c.iff. & 583.0 & 582.9 & 645.0 & 831.9 & 878.0 \\
\hline \multirow[t]{2}{*}{ Total imports, f.o.b. } & 495.6 & 495.5 & 543.0 & 707.1 & 746.3 \\
\hline & \multicolumn{5}{|c|}{ (In percent of total imports, c.i.f.) } \\
\hline Food & 6.1 & 6.8 & 5.2 & 7.0 & 7.5 \\
\hline Rice & 2.1 & 2.2 & 1.5 & 3.7 & 4.2 \\
\hline Other & 3.9 & 4.6 & 3.7 & 3.3 & 3.3 \\
\hline Energy (petroleum) & 14.6 & 12.8 & 14.0 & 19.3 & 15.0 \\
\hline Equipment goods & 18.2 & 18.8 & 18.2 & 15.2 & 14.7 \\
\hline Raw materials and spare parts & 17.1 & 15.6 & 15.1 & 14.8 & 11.7 \\
\hline Consumer goods & 15.1 & 18.5 & 17.5 & 10.3 & 11.8 \\
\hline Other imports (including EPZ) ${ }^{\prime}$ & 28.9 & 27.3 & 30.0 & 33.4 & 39.3 \\
\hline Total imports, c.i.f. & 100.0 & 100.0 & 100.0 & 100.0 & 100.0 \\
\hline
\end{tabular}

Sources: Contral Bank of Madagascar; and Fund staff estimates.

'Includes the imports of the enterprises set up in the export processing zone (EPZ)

and enterprises under special tax regimes (ARD). 
Table 40. Madagascar: Direction of Trade, 1997-2001 ${ }^{1}$ (In percent of total)

\begin{tabular}{|c|c|c|c|c|c|}
\hline & 1997 & 1998 & 1999 & 2000 & 2001 \\
\hline Exports, foob. & 100.0 & 100.0 & 100.0 & 100.0 & 100.0 \\
\hline European Union & 54.2 & 56.6 & 43.3 & 46.5 & 33.3 \\
\hline Of which: France & 34.1 & 39.6 & 34.5 & 39.8 & 29.7 \\
\hline Other Europe & 3.6 & 2.0 & 0.4 & 1.4 & 0.9 \\
\hline United States & 4.7 & 5.9 & 5.4 & 22.5 & 13.9 \\
\hline Asia and the Middle East & 11.9 & 8.7 & 17.1 & 11.8 & 12.6 \\
\hline Of which: Japari & 3.2 & 1.9 & 1.4 & 0.8 & 0.6 \\
\hline Africa & 13.0 & 12.4 & 16.8 & 5.1 & 4.6 \\
\hline Of which: Mauritius & 4.9 & 6.9 & 4.1 & 2.3 & 2.6 \\
\hline Réuxion (France) & 5.5 & 3.8 & 3.2 & 1.6 & 1.4 \\
\hline Other countries & 12.5 & 14.4 & 16.9 & 12.7 & 34.7 \\
\hline Imports, c.i.f. & 100.0 & 100.0 & 100.0 & 100.0 & 100.0 \\
\hline European Union & 41.7 & 40.2 & 38.8 & 18.8 & 27.8 \\
\hline Of which: France & 26.0 & 24.1 & 26.8 & 14.6 & 21.5 \\
\hline Other Europe & 1.1 & 1.6 & 0.8 & 0.5 & 0.8 \\
\hline United States & 5.1 & 4.0 & 3.9 & 5.9 & 4.2 \\
\hline Asia and the Middle East & 22.7 & 27.8 & 27.5 & 23.3 & 23.8 \\
\hline Of which: Iran, Islamic Republic of & 2.2 & 7.1 & 0.0 & 0.0 & 0.1 \\
\hline China & 4.9 & 4.7 & 0.1 & 6.9 & 9.1 \\
\hline Japan & 7.0 & 6.2 & 6.6 & 2.9 & 4.4 \\
\hline Africa & 8.2 & 8.3 & 5.4 & 6.0 & 4.3 \\
\hline Of which : Mauritius & 1.0 & 1.1 & 1.6 & 1.5 & 2.9 \\
\hline Réunion (France) & 0.2 & 0.1 & 0.1 & 0.1 & 0.2 \\
\hline South Africa & 6.3 & 6.0 & $\ldots$ & 4.0 & 5.5 \\
\hline Other countries & 21.2 & 18.1 & 23.7 & 45.6 & 39.1 \\
\hline
\end{tabular}

Source: Central Bank of Madagascar.

${ }^{1}$ Problems with the classification of local purchases and sales of export processing zone enterprises prevented the authorities from providing consistent export data for 1999 and import data for 1999 and 2000 . 
Tabie 41. Madagascar; Balance of Services, 1997-2001

(In millions of SDRs, unless otherwise indicated)

\begin{tabular}{|c|c|c|c|c|c|}
\hline & 1997 & 1998 & 1999 & 2000 & 2001 \\
\hline Credit & 200.3 & 217.2 & 244.9 & 279.3 & 286.5 \\
\hline Fteight and insuratice on grods & 3.3 & 3.5 & 4.0 & 4.8 & 8.0 \\
\hline Other transport & 40.4 & 42.8 & 39.1 & 35.0 & 40.2 \\
\hline Travel & 52.9 & 65.5 & 72.8 & 91.9 & 90.2 \\
\hline Investment income & 5.7 & 9.5 & 6.6 & 8.4 & 10.2 \\
\hline Other services, public & 20.9 & 19.6 & 26.9 & 38.7 & 60.6 \\
\hline Other services, privale & 77.1 & 76.3 & 95.6 & 100.6 & 77.3 \\
\hline Debit & 321.6 & 385.2 & 374.1 & 470.8 & 485.6 \\
\hline Freight and insurance ort goods & 79.2 & 78.6 & 78.8 & 104.0 & 119.8 \\
\hline Percent of imports, c.i.f. & 13.6 & 13.5 & 12.2 & 12.5 & 13.6 \\
\hline Other transport & 34.3 & 33.6 & 37.3 & 57.1 & 62.3 \\
\hline Travel & 56.9 & 84.8 & 81.4 & 87.9 & 302.1 \\
\hline lnvestment income & 44.8 & 72.2 & 46.2 & 63.7 & 83.4 \\
\hline Inierest & 39.8 & 67.2 & 39.8 & 43.7 & 44.4 \\
\hline Dividends & 5.0 & 5.0 & 6.4 & 20.0 & 30.0 \\
\hline Other services, public & 69.4 & 78.2 & 87.0 & 96.0 & 68.0 \\
\hline Government expenditures & 10.7 & 14.8 & 17.4 & 19.6 & 20.8 \\
\hline Services linked to project loans and grants & 58.7 & 63.4 & 69.6 & 76.4 & 47.2 \\
\hline Other services, private & 37.0 & 37.9 & 43.4 & 62.1 & 50.0 \\
\hline Net services & -121.3 & -168.0 & -129.2 & -191.5 & -199.1 \\
\hline Nonfactor services & -82.2 & -115.4 & -89.6 & -136.2 & -125.9 \\
\hline Factor services & -39.1 & -52.6 & -39.6 & -55.3 & .73 .2 \\
\hline
\end{tabular}

Sources: Central Bank of Madagascar; and Fund staff estimates. 
Table 42. Madagascar: Stock of External Debt, 1997-2001

(In millions of SDRs, unless otherwise indicated)

\begin{tabular}{|c|c|c|c|c|c|}
\hline & 1997 & 1998 & 1999 & 2000 & 2001 \\
\hline Medium- and long-term official debt & $2,448.9$ & $2,473.2$ & $2,562.4$ & $2,668.8$ & $2,633.3$ \\
\hline Bílateral creditors & $1,187.2$ & $1,173.1$ & $1,173.4$ & $1,163.9$ & $1,108.1$ \\
\hline Paris Club ' & $1,169.7$ & $1,153.9$ & $1,144.7$ & $1,136.2$ & $1,080.4$ \\
\hline Other countries & 17.6 & 19.3 & 28.6 & 27.7 & 27.7 \\
\hline International organizations & $1,256.6$ & $1,296.5$ & $1,386.8$ & $1,502.6$ & $1,522.0$ \\
\hline IMF & 51.5 & 41.2 & 45.8 & 80.0 & 101.4 \\
\hline Others & $1,205.2$ & $1,255.3$ & $1,341.0$ & $1,422.7$ & $1,420.6$ \\
\hline Of which: World Bank Group & 903.4 & 953.0 & $1,020.7$ & $1,094.1$ & $1,092.7$ \\
\hline Atrican Development Bank & 28.6 & 23.5 & 23.5 & 248.6 & 23.0 \\
\hline African Development Fund & 189.2 & 194.4 & 194.4 & 229.5 & 304.9 \\
\hline Private creditors & 5.0 & 3.6 & 2.3 & 2.3 & 3.2 \\
\hline Commercial banks & 0.7 & 0.5 & 0.4 & 2.3 & 3.2 \\
\hline Others & 4.3 & 3.1 & 1.9 & 0.0 & 0.0 \\
\hline Total arrears & 409.4 & 355.7 & 386.2 & 455.0 & 499.1 \\
\hline Paris Club $^{1}$ & 75.3 & 4.2 & 40.0 & 89.9 & 140.3 \\
\hline Other bilateral creditors & 301.0 & 317.0 & 312.3 & 345.3 & 340.8 \\
\hline International organizations & 1.0 & 0.0 & 0.0 & 0.0 & 0.1 \\
\hline Private creditors & 32.1 & 34.5 & 33.9 & 19.8 & 17.9 \\
\hline Total external debt outstanding ${ }^{2}$ & $2,858.3$ & $2,828.9$ & $2,948.6$ & $3,123.9$ & $3,132.4$ \\
\hline \multicolumn{6}{|l|}{ Memorandum items: } \\
\hline Total external debtGDP (in percent) & 111.1 & 102.6 & 108.3 & 106.4 & 88.1 \\
\hline \multicolumn{6}{|l|}{ Total external debt } \\
\hline (in percent of exports of goods and nonfactor services) & 509.2 & 479.2 & 437.5 & 346.8 & 311.7 \\
\hline Total debt to official creditors after debt relief & $2,821.2$ & $2,790.8$ & $2,912.5$ & $3,101.7$ & $3,111.3$ \\
\hline
\end{tabular}

Sources: Central Bank of Madagascar; and Fund staff estimates.

${ }^{1}$ Reflects Paris Club flow rescheduling on Naples terms obtained for the period January 1997. July 2000 and assumes that agreements with all Paris Club creditors became effective in 1997.

${ }^{2}$ After traditional debt relief (Naples flow rescheduling of 1997). 